Issued by Sandia Laboratories, operated for the United States Department of Energy by Sandia Corporation.

\section{NOTICE}

This report was prepared as an account of work sponsored by the United States Government. Neither the United States nor the Department of Energy, nor any of their employees, nor any of their contractors, subcontractors, or their employees, makes any warranty, express or implied, or assumes any legal liability or responsibility for the accuracy, completeness or usefulness of any information, apparatus, product or process disclosed, or represents that its use would not infringe privately owned rights.

Printed in the United States of America

Available from

National Technical Information Service

U. S. Department of Commerce

5285 Port Royal Road

Springfield, VA 22161 


\section{DISCLAIMER}

This report was prepared as an account of work sponsored by an agency of the United States Government. Neither the United States Government nor any agency Thereof, nor any of their employees, makes any warranty, express or implied, or assumes any legal liability or responsibility for the accuracy, completeness, or usefulness of any information, apparatus, product, or process disclosed, or represents that its use would not infringe privately owned rights. Reference herein to any specific commercial product, process, or service by trade name, trademark, manufacturer, or otherwise does not necessarily constitute or imply its endorsement, recommendation, or favoring by the United States Government or any agency thereof. The views and opinions of authors expressed herein do not necessarily state or reflect those of the United States Government or any agency thereof. 


\section{DISCLAIMER}

Portions of this document may be illegible in electronic image products. Images are produced from the best available original document. 


\author{
NUREG/CR-0481 \\ SAND77-1872 \\ $\mathrm{R}-7$
}

\title{
AN ASSESSMENT OF STRESS-STRAIN DATA SUITABLE FOR FINITE-ELEMENT ELASTICNPLASTIC ANALYSIS OF \\ SHIPPING CONTAINERS
}

H. J. Rack

G. A. Knorovsky

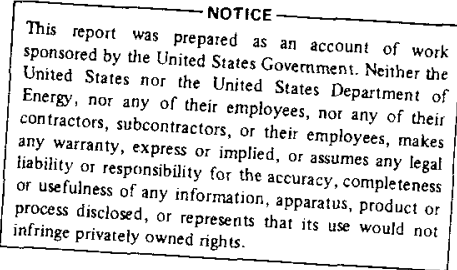

Date Published: September 1978

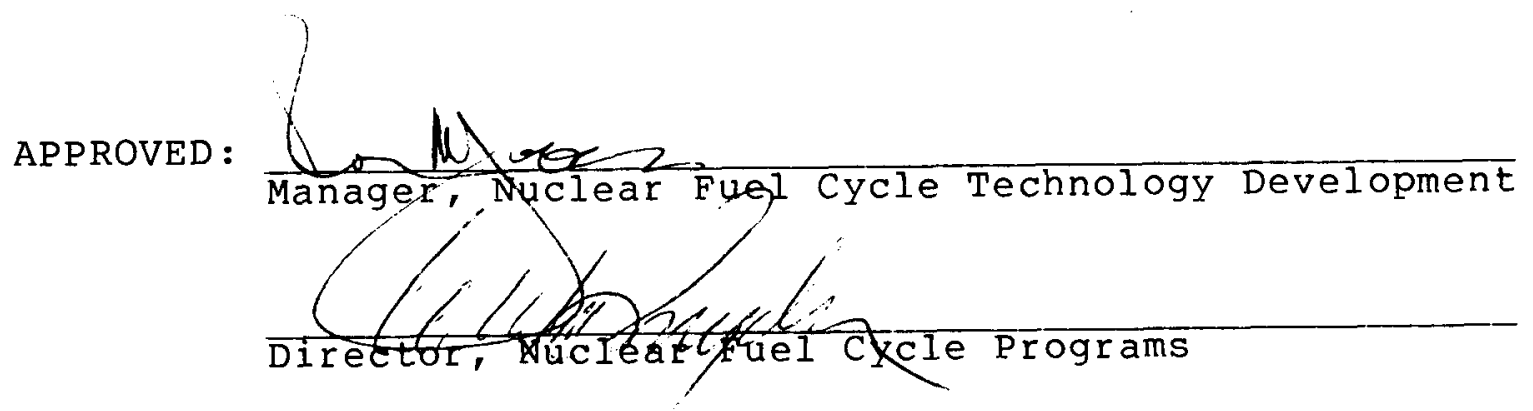

Sandia Laboratories<smiles>[13CH3][AsH2]</smiles>

Albuquerque, New Mexico 87185

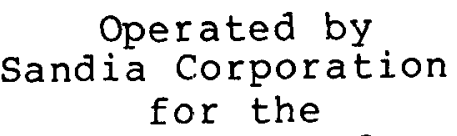

U. S. Department of Energy

This document is

\section{PUBLICLY RELEASABLE}

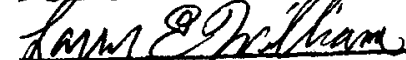

Authonzing Official

Date: $05 / 02 / 2007$
Prepared for

Division of Safeguards, Fuel Cycle and Environmental Research Office of Nuclear Regulatory Research

U. S. Nuclear Regulatory Commission

Under Interagency Agreement DOE 40-550-75

NRC FIN No. AI045 
]

,

.

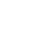

. 


\begin{abstract}
Stress-strain data which describes the influence of strain rate and temperature on the mechanical response of materials presently being used for light water reactor shipping containers have been assembled. Selection of data has been limited to that which is suitable for use in finite-element elastic-plastic analysis of shipping containers (e.g., they must include complete material history profiles). Based on this information, recommendations have been made for further work which is required to complete the necessary data base.
\end{abstract}


]

.

,

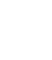

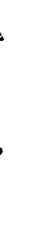




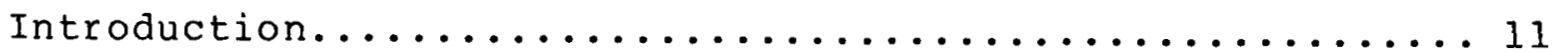

Materials............................... 12

Mechanical Properties....................... 12

Austenitic stainless steels................. 12

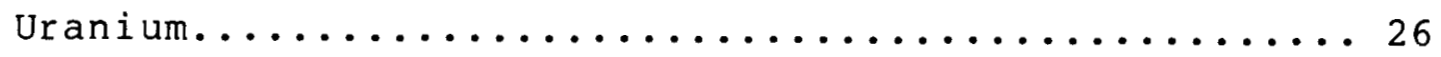

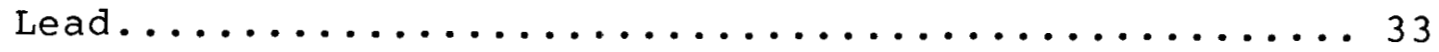

Summary and Recommendations $\ldots \ldots \ldots \ldots \ldots \ldots \ldots \ldots \ldots \ldots$

Mechanical Properties.................... 44

Thermal Expansion...................... 44

Elastic Properties..................... 45

References............................ 46

APPENDIX A - Thermal Expansion Behavior of Selected Stainless Steels, Lead, and Uranium........ 51

Stainless steels....................... 51

Uranium.......................... 53

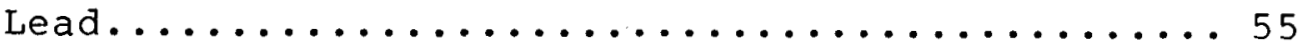

APPENDIX B - Elastic Properties of Selected Stainless Steels, Uranium, and Lead.............. 57

Stainless steels.................... 57

Uranium......................... 65

Lead.......................... 66

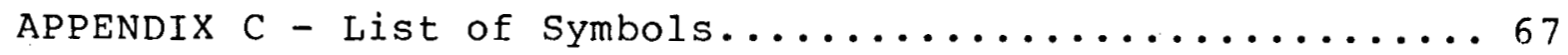

APPENDIX D - References.......................6 68 
TABLES

Number

$\underline{\text { Page }}$

I Chemical Composition of LWR Shipping Cask Materials. 13

I Material Procurement Specifications for Light Water Reactor Shipping Casks..................... 14

II Stress-Strain Curve Availability for Selected

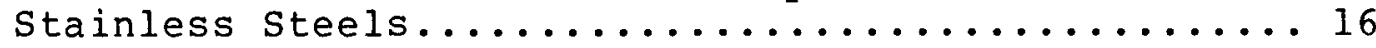

IV Tensile Properties of Representative Stainless

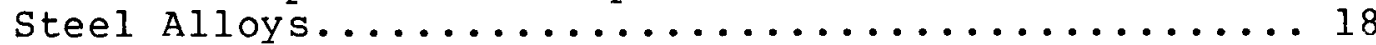

V Typical Parametric Representations Proposed for Austenitic Stainless Steels................... 25

A-I Thermal Linear Expansion of Stainless Stee1...... 52

A-II Thermal Linear Expansion of Polystalline a-Uranium.. 54

B-I Effect of Temperature on the Elastic Constants of Selected stainless steels.................. 58

B-II Young's Modulus for Annealed 304 Stainless steel.................................. 59

B-III Shear Modulus for Annealed 304 Stainless Steel..... 59

B-IV Poisson's Ratio for Annealed 304 Stainless Steel..............................60

B-V Young's Modulus for Annealed 316 Stainless

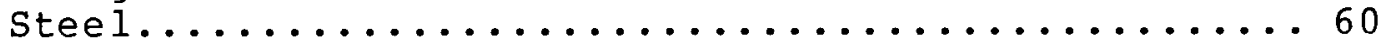

B-VI Shear Modulus for Annealed 316 stainless Steel.....6 61

B-VII Poisson's Ratio for Annealed 316 Stainless steel................................ 61

B-VIII Probable Values for Elastic Moduli of Non-textured Polycrystalline Uranium.................. 65 


\section{ILLUSTRATIONS}

Figure

Page

1 Stress-strain curves for 321 stainless steel sheet

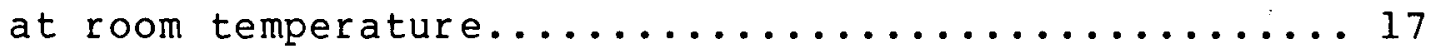

2 Compressive stress-strain curves for 321 stainless steel sheet at room and elevated temperatures........ 17

3 Stress-strain curves for 321 stainless steel sheet at room and elevated temperatures............... 17

4 Stress-strain curves for 321 stainless steel sheet at room and elevated temperatures................ 17

5 Stress-strain curves for 347 stainless steel sheet at room and elevated temperatures............... 17

6 Stress-strain curves to failure at room and elevated temperatures for 347 stainless stee $1 \ldots \ldots \ldots \ldots \ldots \ldots$

7 Heat-to-heat variation in stress-strain diagrams for 304 stainless steel tested at (a) $297 \mathrm{~K}$, (b)

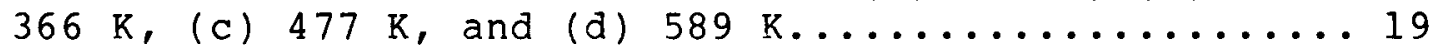

8 Heat-to-heat variation in stress-strain diagrams for 316 stainless steel at (a) $297 \mathrm{~K}$, (b) $366 \mathrm{~K}$, (c)

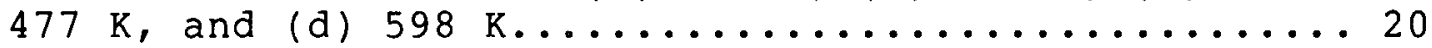

9 Engineering stress versus engineering strain for the 301 stainless steel tested at a strain rate of

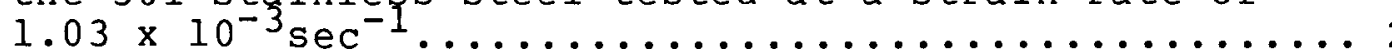

10 Tensile properties of standard grades of austenitic steel in temperature range -200 to $+800^{\circ} \mathrm{C} \ldots \ldots \ldots \ldots . \ldots 22$

11 Effect of alloy stability on tensile properties of austenitic steels........................ 22

12. Relationship between strain rate and temperature for serrated flow in type 330 stainless steel....... 23

13 The effect of test temperature $\left(-200^{\circ} \mathrm{C}\right.$ to $\left.900^{\circ} \mathrm{C}\right)$ on the tensile properties and fracture of uranium....... 28

14 Ductile/brittle transifign temperature versus $\log _{e}$ (grain diameter) -172 for $U-300 \mathrm{ppm} \mathrm{C}$, $50 \mathrm{ppm} \mathrm{Al,} 60 \mathrm{ppm} \mathrm{Si}$, and $50 \mathrm{ppm}$ Fe.............. 29

15 Load-elongation curves of -uranium ( $U$ - 140 ppm C,

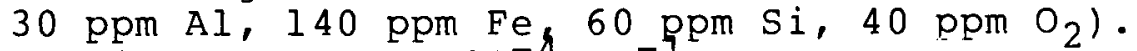
Strain rate $2.6 \times 10^{-4}$ sec $^{-1} \ldots \ldots \ldots \ldots \ldots \ldots \ldots \ldots \ldots . \ldots \ldots$ 
ILLUSTRATIONS (cont.)

Figure

$\underline{\text { Page }}$

16 Influence of strain rate on the true-stress versus true-strain curves of annealed polycrystalline

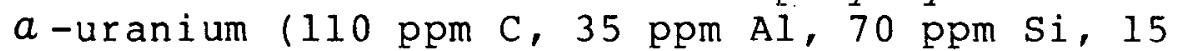
ppm $\mathrm{Cr}, 8 \mathrm{ppm} \mathrm{Mo,} 60 \mathrm{ppm} \mathrm{Fe,} 40 \mathrm{ppm} \mathrm{Ni}, 6 \mathrm{ppm} \mathrm{Cu}$ )

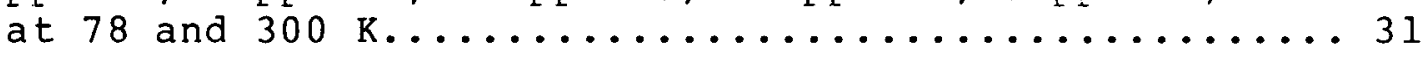

17 Stress-strain curves for alpha-extruded uranium ( $20 \mathrm{ppm} \mathrm{C,} 12 \mathrm{ppm} \mathrm{N}, 53 \mathrm{ppm} \mathrm{Fe}, 27 \mathrm{ppm} \mathrm{Si}, 1.3 \mathrm{ppm}$

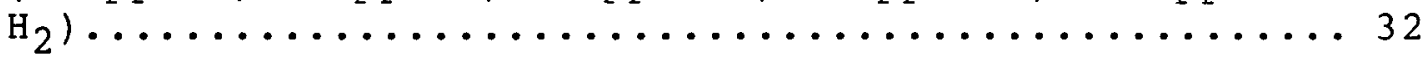

18 Mechanical properties of uranium - 2 weight percent Mo.......................... 34

19 Phase diagrams for (a) copper-lead and (b)

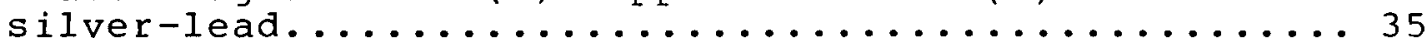

20 Triplicate tensile stress-strain curves to failure at a strain rate of $1 \times 10^{-3} \sec ^{-1} \ldots \ldots \ldots \ldots \ldots \ldots$

21 Triplicate tensile stress-strain curyes to 2 percent strain at a strain rate of $8.3 \times 10^{-5} \sec ^{-1} \ldots \ldots \ldots \ldots 38$

22 Effect of strain rate on the tensile stress-strain curves at 311 and $393 \mathrm{~K}$ (triplicate curves)........ 39

23 Triplicate compression stress-strain curves to 5 percent strain at a strain rate of $2.5 \times 10^{-4} \mathrm{sec}^{-1} \ldots 40$

24 stress-strain curves for $\mathrm{Pb} \ldots \ldots \ldots \ldots \ldots \ldots \ldots \ldots \ldots$

25 Influence of strain rate on flow stress of $\mathrm{Pb} \ldots \ldots . .4 \mathrm{l}$ 26 Tensile strength and elongation as a function of
test temperature at a strain rate of $8.3 \times 10^{-4}$

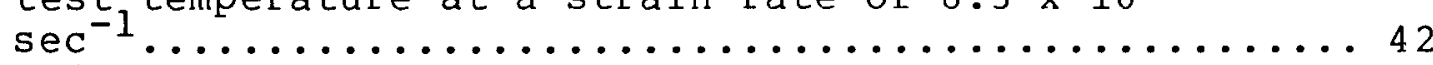

27 Quasi-static true stress-strain curves for chemical lead test specimens in tension.................4 42

28 Quasi-static true stress-strain curves for chemical lead test specimens in compression............... 42

29 Stress-strain curves of lead for four strain-rate ranges............................. 43 
ILLUSTRATIONS (cont.)

Figure

Page

A-1 Thermal expansion of 304 and 321 stainless steel.....53

A-2 Thermal expansion behavior of a-uranium.......... 54

A-3 Thermal expansion behavior of lead............. 56

B-1 Young's modulus of 304 ss, annealed...............62

B-2 Young's modulus of 316 ss, annealed.............. 62

B-3 Shear modulus of 304 ss, annealed............... 63

B-4 Shear modulus of 316 ss, annealed................63

B-5 Poisson's ratio of 304 ss, annealed............... 64

B-6 Poisson's ratio of $3165 s$, annealed...............64

B-7 Young's modulus of pure polycrystalline uranium as

a function of temperature................... 65

B-8 Young's modulus of lead....................66 

.
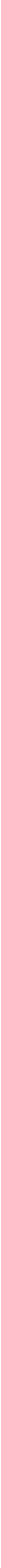
AN ASSESSMENT OF STRESS-STRAIN DATA SUITABLE FOR FINITE-ELEMENT ELASTIC-PLASTIC ANALYSIS OF SHIPPING CONTAINERS

\section{Introduction}

- Recent progress in finite-element elastic-plastic analysis has brought with it a requirement for a more detailed description of a material's response to imposed mechanical and thermal loadings. Unfortunately, metallurgists have in the past typically reported the influence of such variables as temperature and strain rate only on selected properties (e.g., yield strength or tensile elongation) rather than the generalized elastic-plastic representation required for modern computer program applications. Notwithstanding this shortcoming, a body of literature exists that can form the basis for advanced computer-aided design. The purpose of this report is to assess and compile available data, particularly those relevant to materials which are being used for light water reactor (LWR) spent fuel shipping container primary structures. Consequently, this assessment has been limited to selected stainless steels, uranium, and chemical lead. It includes, where possible, data on the stress-strain behavior of these materials over a range of strain rates $\left(10^{-5}\right.$ to $\left.10^{2} \mathrm{sec}^{-1}\right)$ and temperatures $\left(-40\right.$ to $320^{\circ} \mathrm{C} ;-40^{\circ} \mathrm{F}$ to $\left.620^{\circ} \mathrm{F}\right)$ thought to be typical of shipping cask environments.

This survey has considered only uniaxial deformation, tensile or compressive, and does not contain any multiaxial information. In addition, fracture, creep, and cyclic loading conditions have been excluded. Since the data sources examined in 
this study generally did not cite whether the values given were average or minimum data reported are thought to be typical of the materials being examined rather than representing either average or minimum values.

This report first lists the materials used in typical shipping cask designs and their procurement specifications. It then discusses the available mechanical properties data, particularly stress-strain curves, treating each of the specific materials in separate subsections. Finally, the report recommends specific areas for further research and data acquisition.

\section{Materials}

Table I lists the chemical compositions of some of the materials presently used for LWR shipping casks. Table II I ists the specific cask being considered and the material specification required for procurement of the requisite structural shapes.

\section{Mechanical Properties}

\section{Austenitic Stainless Steels}

Many investigators have examined austenitic stainless steels, because of their excellent corrosion resistance, creep resistance, and high toughness. However, their studies have tended to neglect the regime of stress/strain-rate/temperature of interest for shipping cask applications.

Probably the most extensive compilation of stress-strain data may be found in studies conducted at the Oak Ridge National 
TABLE I

Chemical Composition of LWR Shipping Cask Materials

(percentage by weight; maximum amount unless otherwise noted)

\begin{tabular}{|c|c|c|c|c|c|c|c|c|c|}
\hline & $\mathrm{c}$ & $\mathrm{Mn}$ & Si & $\mathbf{P}$ & $\mathbf{s}$ & $\mathrm{Cr}$ & $\mathrm{Ni}$ & Mo & Other \\
\hline \multicolumn{10}{|l|}{$\frac{\text { Ferrous }}{\text { Austenitic }}$} \\
\hline $\begin{array}{l}216 \\
304\end{array}$ & $\begin{array}{l}0.08 \\
0.08\end{array}$ & $\begin{array}{l}7.5-9.0 \\
2.0\end{array}$ & $\begin{array}{l}1.0 \\
1.0\end{array}$ & $\begin{array}{l}0.045 \\
0.045\end{array}$ & $\begin{array}{l}0.03 \\
0.03\end{array}$ & $\begin{array}{l}17.5-22.0 \\
18.0-20.0\end{array}$ & $\begin{array}{l}5.0-7.0 \\
8.0-10.5\end{array}$ & $1.0-3.0$ & $0.25 / .5 \mathrm{~N}$ \\
\hline $304 \mathrm{~L}$ & 0.03 & 2.0 & 1.0 & 0.045 & 0.03 & $18.0-20.0$ & $8.0-12.0$ & - & - \\
\hline 308 & 0.08 & 2.0 & 1.0 & 0.045 & 0.03 & $19.0-21.0$ & $10.0-12.0$ & - & - \\
\hline 316 & 0.08 & 2.0 & 1.0 & 0.045 & 0.03 & $16.0-18.0$ & $10.0-14.0$ & $2.0-3.0$ & - \\
\hline $\begin{array}{l}317 \\
321\end{array}$ & $\begin{array}{l}0.08 \\
0.08\end{array}$ & $\begin{array}{l}1.5 \\
2.0\end{array}$ & $\begin{array}{l}1.5 \\
1.0\end{array}$ & $\begin{array}{l}0.040 \\
0.045\end{array}$ & $\begin{array}{l}0.04 \\
0.03\end{array}$ & $\begin{array}{l}18.0-21.0 \\
17.0-19.0\end{array}$ & $\begin{array}{l}9.0-13.0 \\
9.0-12.0\end{array}$ & $\begin{array}{c}3.0-4.0 \\
-\end{array}$ & $\overline{0.7} \mathrm{Ti}$ \\
\hline 347 & 0.08 & 2.0 & 1.0 & 0.045 & 0.03 & $17.0-19.0$ & $9.0-13.0$ & - & $1.1(\mathrm{Cb}+\mathrm{Ta})$ \\
\hline \multicolumn{10}{|l|}{ Ferritic } \\
\hline A333 Gr 1 & 0.03 & $0.4-1.06$. & - & 0.04 & 0.06 & - & - & - & - \\
\hline A514 $(\mathrm{T}-1)$ & $0.1-0.2$ & $0.6-1.0$ & $0.15-0.35$ & 0.035 & 0.04 & $0.4-0.65$ & $0.7-1.0$ & $0.4-0.6$ & $\begin{array}{l}0.03 / 0.08 \mathrm{~V} ; 0.002 / \\
0.006 \mathrm{~B} ; 0.15 / 0.5 \mathrm{Cu}\end{array}$ \\
\hline \multicolumn{7}{|c|}{ 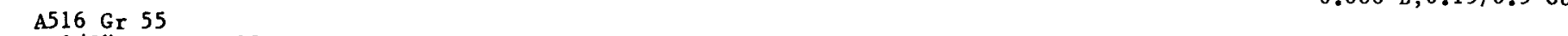 } & - & - & $=0$ \\
\hline 2" & 0.2 & $0.56-1.25$ & $0.13-0.33$ & 0.035 & 0.04 & - & - & - & - \\
\hline 4" & 0.22 & $0.56-1.25$ & $0.13-0.33$ & 0.035 & 0.04 & - & - & - & - \\
\hline 8" & 0.24 & $0.56-1.25$ & $0.13-0.33$ & 0.035 & 0.04 & - & - & - & - \\
\hline 8" & 0.2 & $0.56-1.25$ & $0.13-0.33$ & 0.035 & 0.04 & - & - & - & - \\
\hline \multicolumn{10}{|l|}{$\mathrm{A} 516$ Gr 70} \\
\hline $1 / 2^{\prime \prime}$ & 0.27 & $0.8-1.25$ & $0.13-0.33$ & 0.035 & 0.04 & - & - & - & - \\
\hline $2 "$ & 0.28 & $0.8-1.25$ & $0.13-0.33$ & 0.035 & 0.04 & - & - & - & - \\
\hline 4" & 0.30 & $0.8-1.25$ & $0.13-0.33$ & 0.035 & 0.04 & - & - & - & - \\
\hline 4" & 0.31 & $0.8-1.25$ & $0.13-0.33$ & 0.035 & 0.04 & - & - & - & - \\
\hline 4140 & $0.38-0.43$ & $0.75-1.0$ & $0.20-0.35$ & 0.025 & 0.025 & $0.8-1.1$ & 0.25 & $0.15-0.25$ & $0.25 \mathrm{Cu}$ \\
\hline $\begin{array}{l}4142 \\
4145\end{array}$ & $\begin{array}{l}0.40-0.45 \\
0.43-0.48\end{array}$ & $\begin{array}{l}0.75-1.0 \\
0.75-1.0\end{array}$ & $\begin{array}{l}0.20-0.35 \\
0.2-0.35\end{array}$ & $\begin{array}{l}0.025 \\
0.025\end{array}$ & $\begin{array}{l}0.025 \\
0.025\end{array}$ & $\begin{array}{l}0.8-1.1 \\
0.8-1.1\end{array}$ & $\begin{array}{l}0.25 \\
0.25\end{array}$ & $\begin{array}{l}0.15-0.25 \\
0.15-0.25\end{array}$ & $\begin{array}{l}0.25 \mathrm{Cu} \\
0.25 \mathrm{Cu}\end{array}$ \\
\hline 4340 & $0.38 \sim 0.43$ & $0.6-0.85$ & $0.2-0.35$ & 0.04 & 0.04 & $0.7-0.9$ & $1.6-2.0$ & $0.2-0.3$ & - \\
\hline \multirow{4}{*}{$\begin{array}{l}\text { Precipitation } \\
\text { 17-4 PH } \\
\text { AISI 660 } \\
\text { (A286) }\end{array}$} & Hardening & & & & & & & & \\
\hline & 0.04 & 0.4 & 0.5 & - & - & 16.5 & 4.25 & - & $0.25 \mathrm{Cb} ; 3.6 \mathrm{Cu}$ \\
\hline & 0.08 & 1.35 & 0.5 & - & - & $13.5-16.0$ & $24.0-27.0$ & $1.0-1.5$ & $\begin{array}{l}1.9 / 2.35 \mathrm{Ti} \\
0.25 \mathrm{~A} 1 ; 0.3 \mathrm{~V}\end{array}$ \\
\hline & $\mathrm{Cu}$ & Mn & $\mathrm{Si}$ & $\mathrm{Fe}$ & $\mathrm{Zn}$ & $\mathrm{Cr}$ & $\mathrm{Mg}$ & $\mathrm{Ti}$ & \\
\hline \multicolumn{10}{|l|}{$\frac{\text { Nonferrous }}{\text { Aluminum }}$} \\
\hline 1180 & 0.01 & - & 0.09 & 0.09 & 0.1 & - & - & 0.02 & - \\
\hline 3003 & $0.05-0.2$ & $1.0-1.5$ & 0.6 & 0.7 & 0.25 & $0.04-0.35$ & $0.8-1.2$ & - & - \\
\hline 6061 & $0.15-0.4$ & 0.15 & $0.4-0.6$ & 0.7 & 0.1 & 0.1 & $0.45-0.9$ & 0.15 & - \\
\hline 6063 & 0.10 & 0.10 & $0.2-0.6$ & 0.35 & 0.1 & $0.15-0.35$ & $2.2-2.8$ & 0.1 & - \\
\hline 5052 & 0.10 & 0.10 & - & - & - & - & - & - & $0.045(\mathrm{Si}+\mathrm{Fe})$ \\
\hline Chemical $\mathrm{Pb}$ & $0.04-0.08$ & - & - & 0.002 & 0.001 & - & - & - & $\begin{array}{l}0.005 \mathrm{Bi} ; 0.002 / \\
0.02 \mathrm{Ag} ; 0.002\end{array}$ \\
\hline
\end{tabular}


TABLE II

Material Procurement Speciflcations for Light Water Reactor Shipping Casks

\begin{tabular}{|c|c|c|c|}
\hline Cask & Material & Specification* & Form \\
\hline $\begin{array}{l}\text { NFS-4, NFS-5 } \\
\text { Spent Fue1 Shipping Cask }\end{array}$ & $\begin{array}{l}304 \\
321 \\
347 \\
\text { Bolts Cd Plated } \\
\mathrm{Pb} \\
\mathrm{U}-2 \mathrm{Mo}\end{array}$ & $\begin{array}{l}- \\
\text { A325 } \\
\text { B29 } \\
-\end{array}$ & $\begin{array}{l}\text { plate, sheet, forging } \\
\text { bolts } \\
\text { shielding } \\
\text { shielding }\end{array}$ \\
\hline IF 300 & $\begin{array}{l}216 \\
304 \\
316 \\
317 \\
\mathrm{~A} 514 \\
\mathrm{~A} 516 \\
4340 \\
17-4 \mathrm{PH} \\
3003 \mathrm{A1} \\
6061 \mathrm{~A} 1 \\
6063 \mathrm{A1} \\
\mathrm{Pb}\end{array}$ & $\begin{array}{l}\text { A240 } \\
\text { A182,A240,A351 } \\
- \\
\text { A296** } \\
\text { A514 } \\
\text { A516 } \\
- \\
- \\
- \\
- \\
- \\
\text { B29 }\end{array}$ & $\begin{array}{l}\text { sheet, plate } \\
\text { forging, casting, sheet, plate } \\
\text { valve coupling } \\
\text { cast form } \\
\text { plate } \\
\text { plate } \\
\text { bar } \\
\text { studs, nuts } \\
\text { sheet, plate } \\
\text { sheet, plate } \\
\text { sheet, plate } \\
\text { shielding }\end{array}$ \\
\hline NL 10/24 Rail Cask & $\begin{array}{l}304 \\
4140,4142,4145 \\
17-4 \mathrm{PH} \\
660(\mathrm{~A} 286) \\
1180 \mathrm{Al}, 5052-\mathrm{H} 32 \\
\mathrm{~Pb} \\
\mathrm{U} \\
\mathrm{Ag}-15 \mathrm{In}-5 \mathrm{Cd}\end{array}$ & $\begin{array}{l}\text { A240, A312, A336, } \\
\text { A182,A269 } \\
\text { A193 } \\
- \\
\text { A453 } \\
- \\
\text { B29 } \\
\text { NLI } 7065 \$ 1 \\
-\end{array}$ & $\begin{array}{l}\text { sheet, plate, forging } \\
\text { bolting } \\
\text { pipe \& fittings, tubing } \\
\text { bolting } \\
\text { - } \\
\text { shielding } \\
\text { neutron shield } \\
\text { neutron absorber }\end{array}$ \\
\hline TN 8 , TN 9 & $\begin{array}{l}304 \\
304 \mathrm{~L} \\
\mathrm{~A} 333 \\
\mathrm{~A} 516 \\
4140,4142,4145 \\
4340 \\
\mathrm{~Pb} \\
\mathrm{Cu} 1 / 2 \text { hard }\end{array}$ & $\begin{array}{l}\text { SA320 B8 } \\
- \\
\text { A333 } \text { gr } 55 \\
\text { A516 gr } 55 \\
\text { SA320 L7 } \\
\text { SA320 L43 } \\
\text { B29 } \\
\text { B152 }\end{array}$ & $\begin{array}{l}\text { bolts } \\
\text { plate, sheet, forgings } \\
\text { pipe } \\
\text { plate } \\
\text { bolting } \\
\text { bolting } \\
\text { shielding } \\
\text { plate }\end{array}$ \\
\hline
\end{tabular}

* Refers to SAE or ASTM specification (with the exception of the NL specification for U). **Includes additional composition restrictions imposed by manufacturer. 
Laboratory and the Hanford Engineering Development Laboratory. Since these examinations were in support of the LMFBR program, they have been principally concerned with temperatures above those of concern to this program. Table III summarizes the applicable data banks presently available from these institutions. These investigators have shown that while the yield strength of 304 stainless steel at $25^{\circ} \mathrm{C}\left(77^{\circ} \mathrm{F}\right)$ increases by $48 \mathrm{MN} / \mathrm{m}^{2}$ per decade increase in strain rate, the overall stressstrain behavior of the alloy does not appear to be radically altered by these rate changes.

The stress-strain curves shown in Figures 1 through 6 and Table IV should be considered only as typical of the respective alloys and product forms. Studies [3] of different product forms produced from a single heat of 304 stainless steel have demonstrated that even when chemistry variables are eliminated, variations in processing operations can cause large changes in the stress-strain response. This effect of processing variations is further complicated by the rather wide chemistry allowables shown in Table I. Combinations of these factors--different chemistry and processing--have led to considerable property variability for nominally identical alloys. Examples of this heat-to-heat variability are given in Figures 7 and 8 for 304 and 316 stainless steels, respectively.

Two additional phenomena, (i.e., the formation of deformation induced martensite and dynamic strain-aging) have been observed during tensile straining of austenitic stainless steels. The former can result in drastic changes in the stress-strain 
TABLE III

Stress-Strain Curve Availability for Selected Stainless Steels*

Strain Rate $\left(\sec ^{-1}\right)$

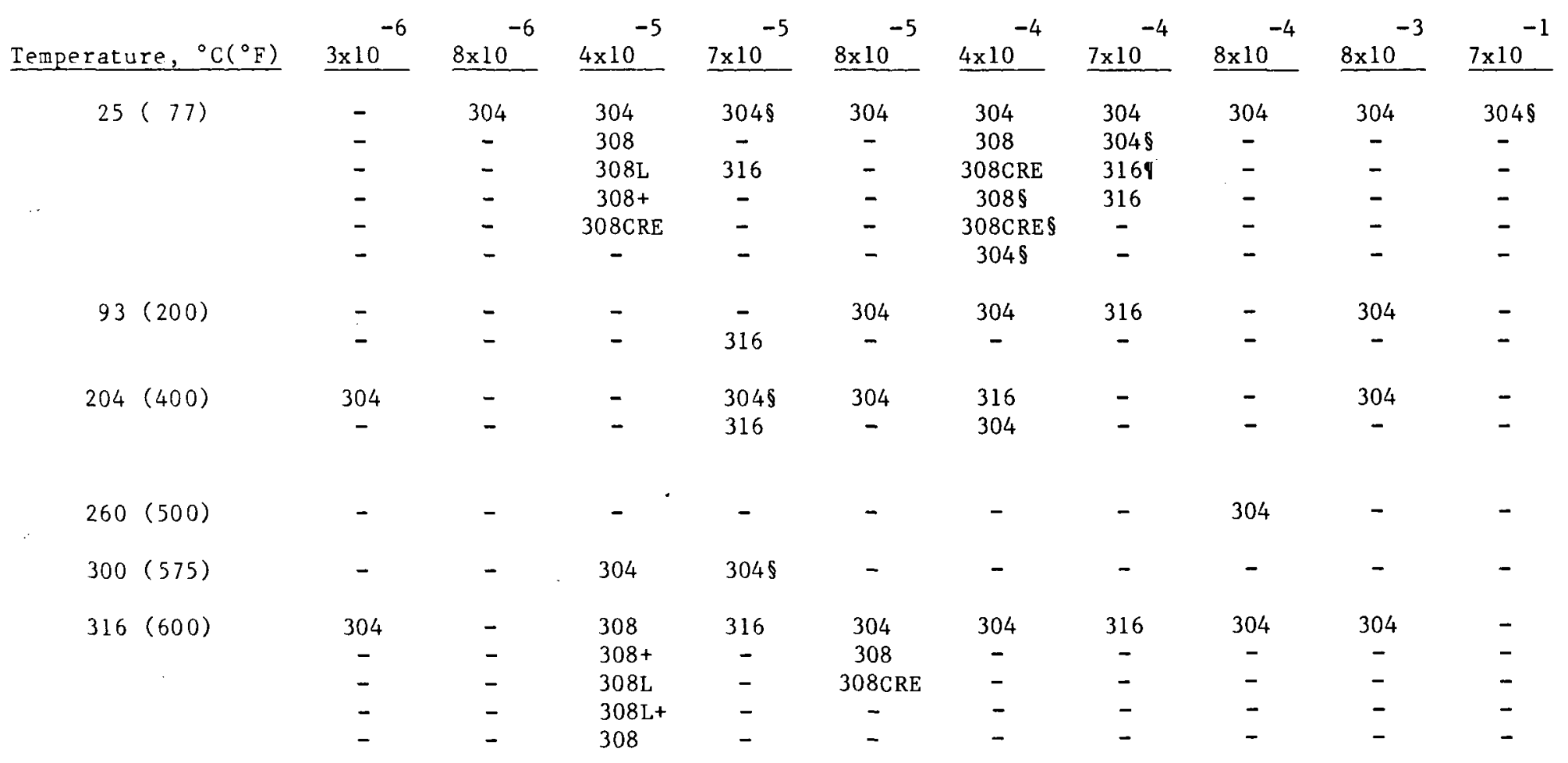

*A1. 308 variations are weld metal. +Irradiated

SAged (various treatments)

IWeld Material 


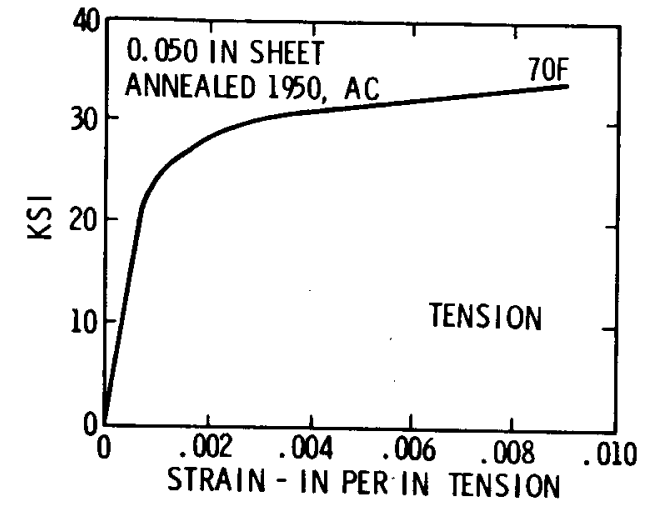

Figure 1. Stress-strain curves for 321 stainless steel sheet at room temperature [13].

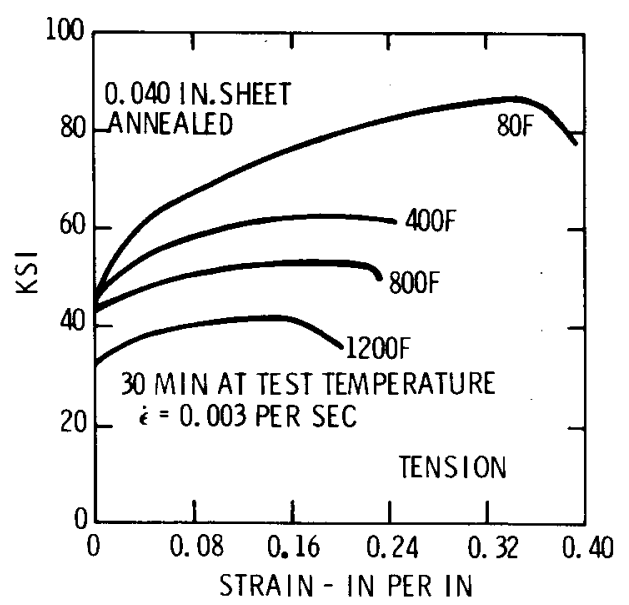

Figure 4. Stress-strain curves for 321 stainless steel sheet at room and elevated temperatures [1].

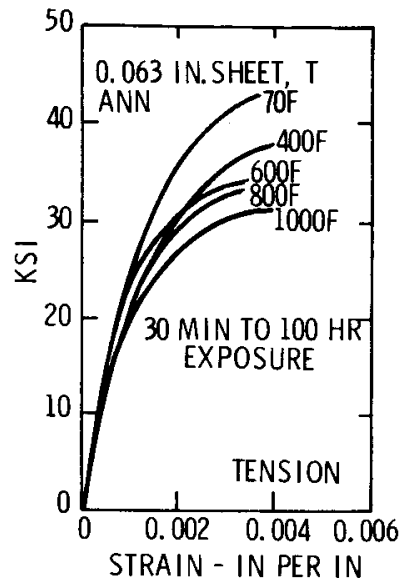

Figure 2. Compressive stress-strain curves for 321 stainless steel sheet at room and elevated temperatures [1].

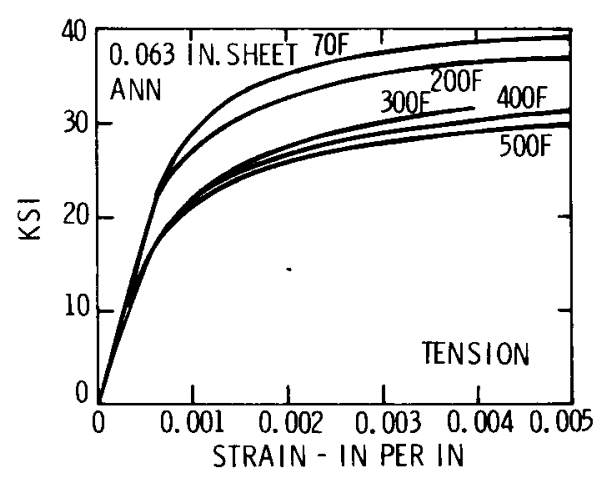

Figure 5. Stress-strain curves for 347 stainless steel sheet at room and elevated temperatures [1].

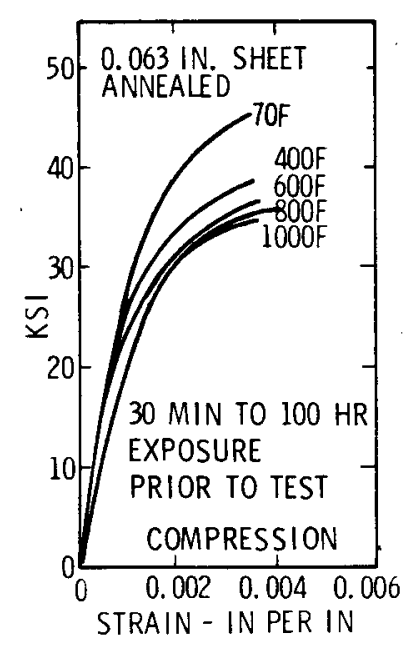

Figure 3. Stress-strain curves for 321 stainless steel sheet at room and elevated temperatures [1].

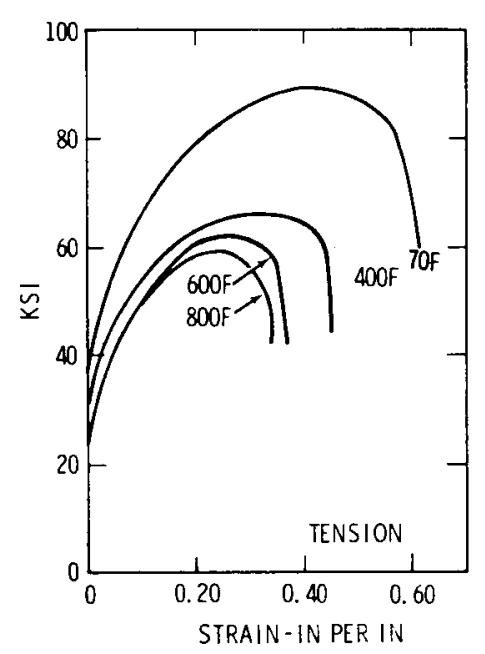

Figure 6. Stress-strain curves to failure at room and elefailure at room and elestainless steel [I]. 
TABLE IV

Tensile Properties of Representative Stainless Stee 1 Alloys

$\underline{\text { Test Temperature }{ }^{\circ} \mathrm{C}} \quad-50 \quad-20 \quad 0 \quad \underline{20} \quad \underline{100} \quad \underline{200} \quad \underline{300} \quad \underline{400}$

$\begin{array}{lllllllll}\text { Tensile Strength } & 159.7 & 141.6 & 127.4 & 89.6 & 68.8 & 63.4 & 63.2 & 63.2\end{array}$ ksi

Stress ksi@

Type $0.02 \%$ strain

$\begin{array}{llllllll}24.6 & 28.0 & 28.7 & 28.2 & 19.7 & 15.2 & 14.3 & 12.8\end{array}$

$\begin{array}{llllllll}28.7 & 31.4 & 31.8 & 30.0 & 21.5 & 17.9 & 16.6 & 15.5\end{array}$

$\begin{array}{llllllll}33.8 & 33.2 & 33.6 & 31.4 & 22.8 & 19.0 & 17.7 & 16.6\end{array}$

$\begin{array}{llllllll}34.3 & 34.9 & 35.2 & 32.7 & 24.2 & 20.2 & 18.8 & 17.5\end{array}$

$0.1 \%$ strain

$0.2 \%$ Strain

Elongation (\%)

$\begin{array}{llllllll}50.1 & 55.9 & 64.7 & 70.8 & 58.5 & 49.1 & 44.7 & 45.5\end{array}$

Reduction of Area (\%)

$\begin{array}{llllllll}71.0 & 67.0 & 75.0 & 77.4 & 78.5 & 75.2 & 69.6 & 72.0\end{array}$

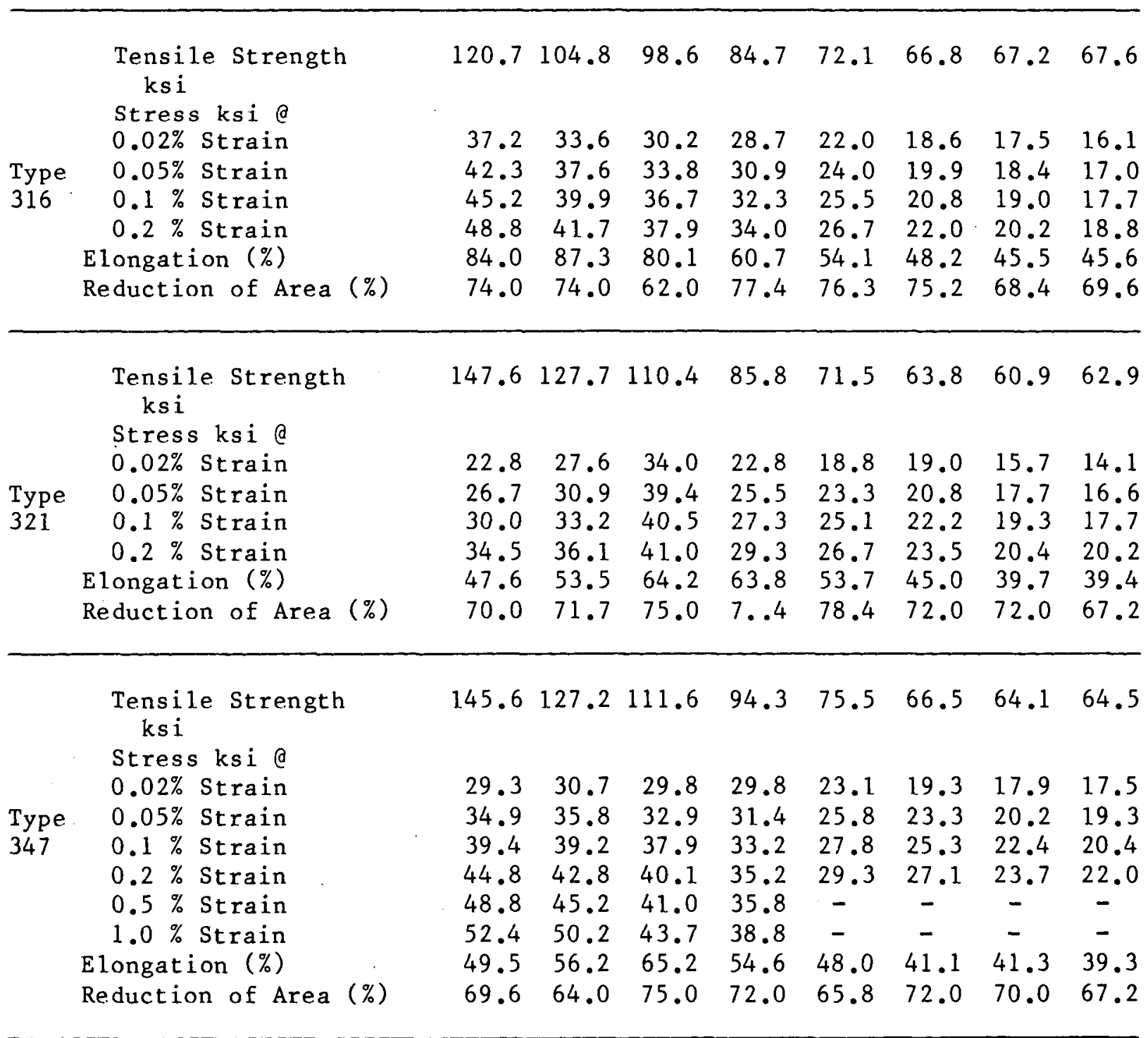



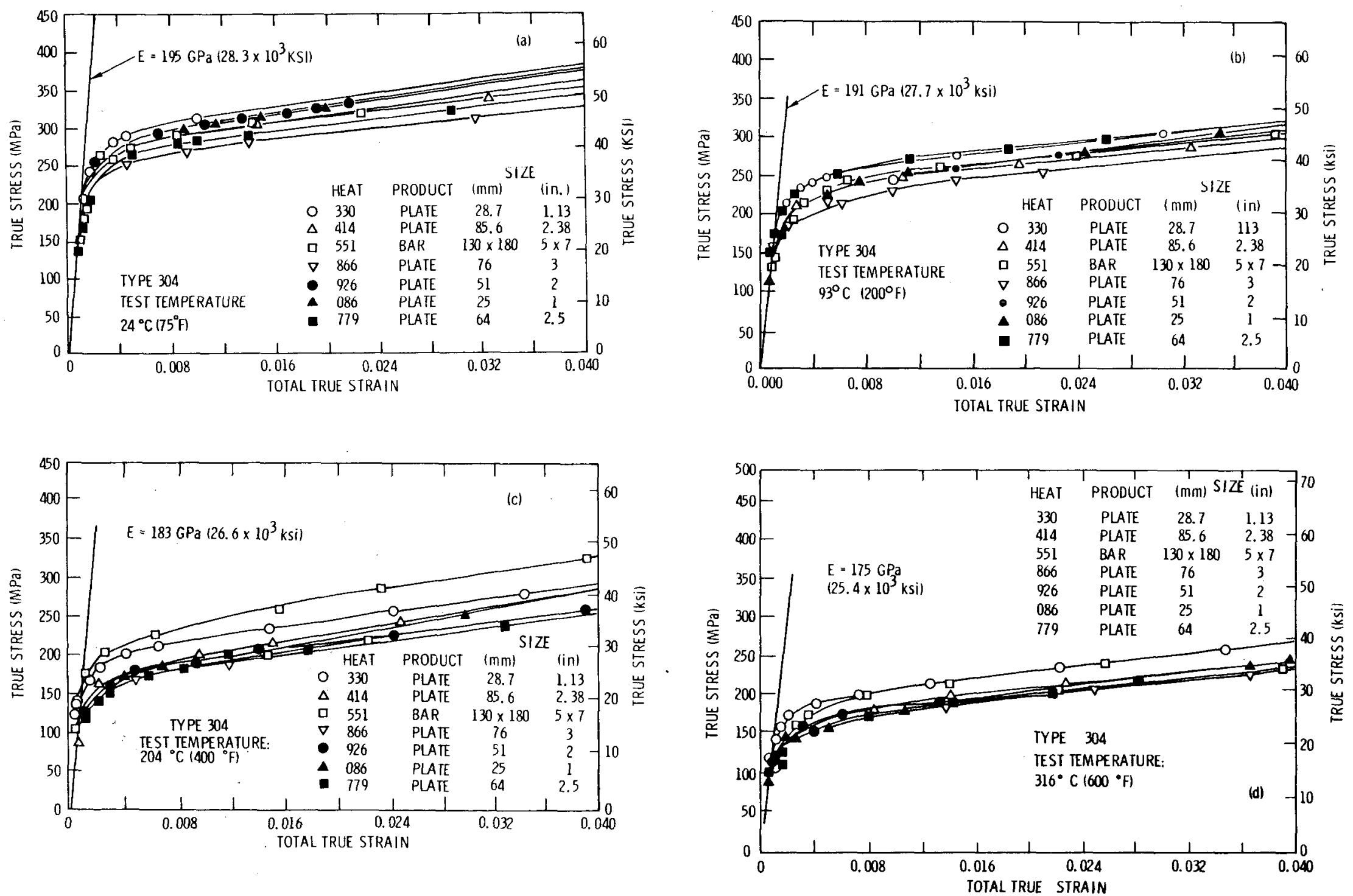

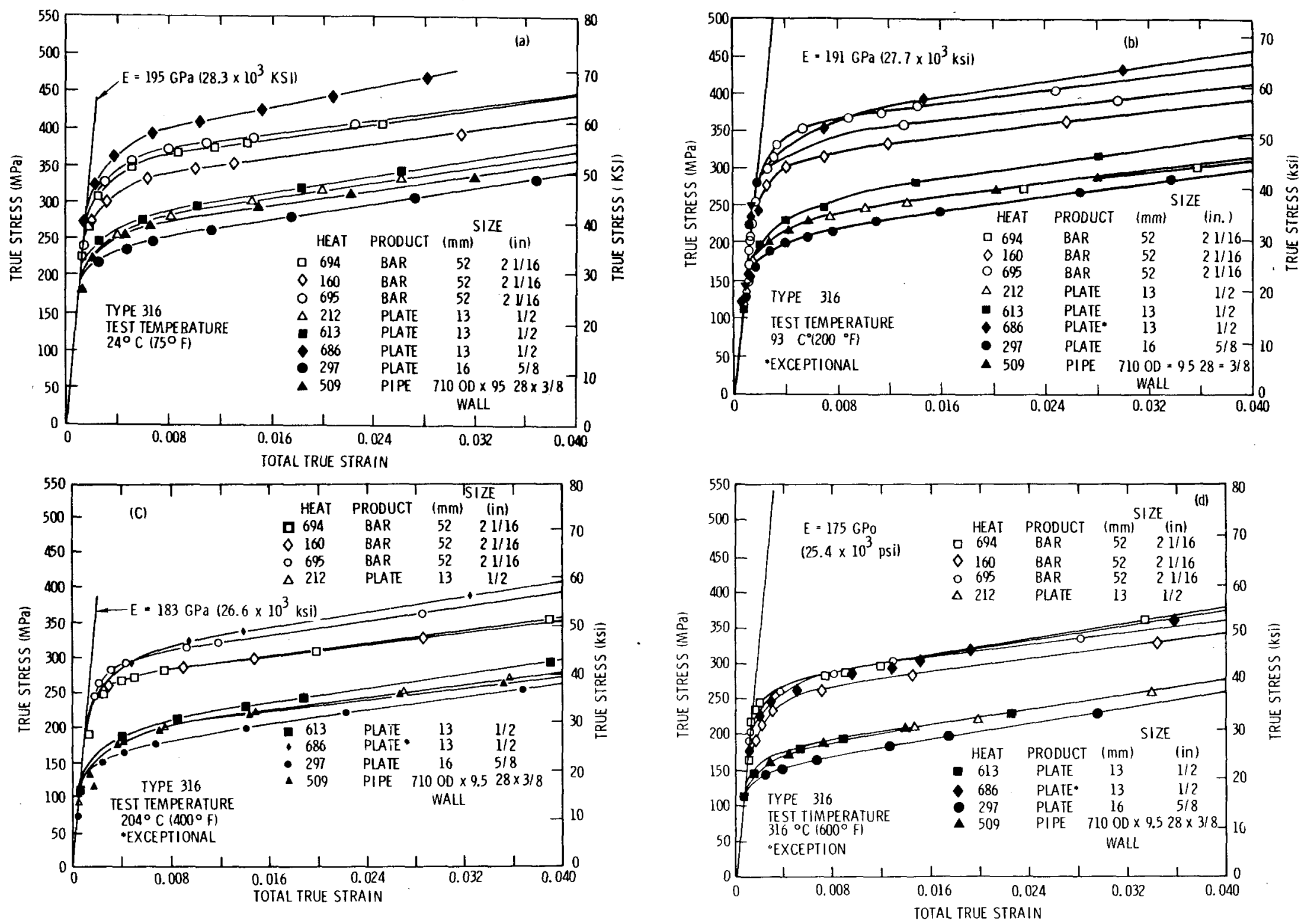

Figure 8. Heat-to-heat variation in stress-strain diagrams for 316 stainless steel at (a) $24^{\circ} \mathrm{C}$, (b) $93^{\circ} \mathrm{C}$, (c) $204^{\circ} \mathrm{C}$, and (d) $316^{\circ} \mathrm{C}$ [4]. 
behavior. Figure 9 shows a representative example of the effect of test temperature on the mechanical response of 301 , an alloy less stable (i.e., more prone to martensite formation) than 304 . Normally, stable austenitic stainless steels show an increase in yield and ultimate strengths with decreasing temperatures below ambient [2]. On the other hand, martensite-forming grades exhibit a slight decrease in yield but a rapid increase in ultimate strength. A sharp maxima in the tensile ductility also occurs (Figures 10 and 11). Although austenitic stainless steels (such as 304) which are used for LWR shipping casks are typically thought to be quite stable with respect to martensite formation, it is possible this transformation might occur in containers stressed at low temperatures. Unfortunately, the

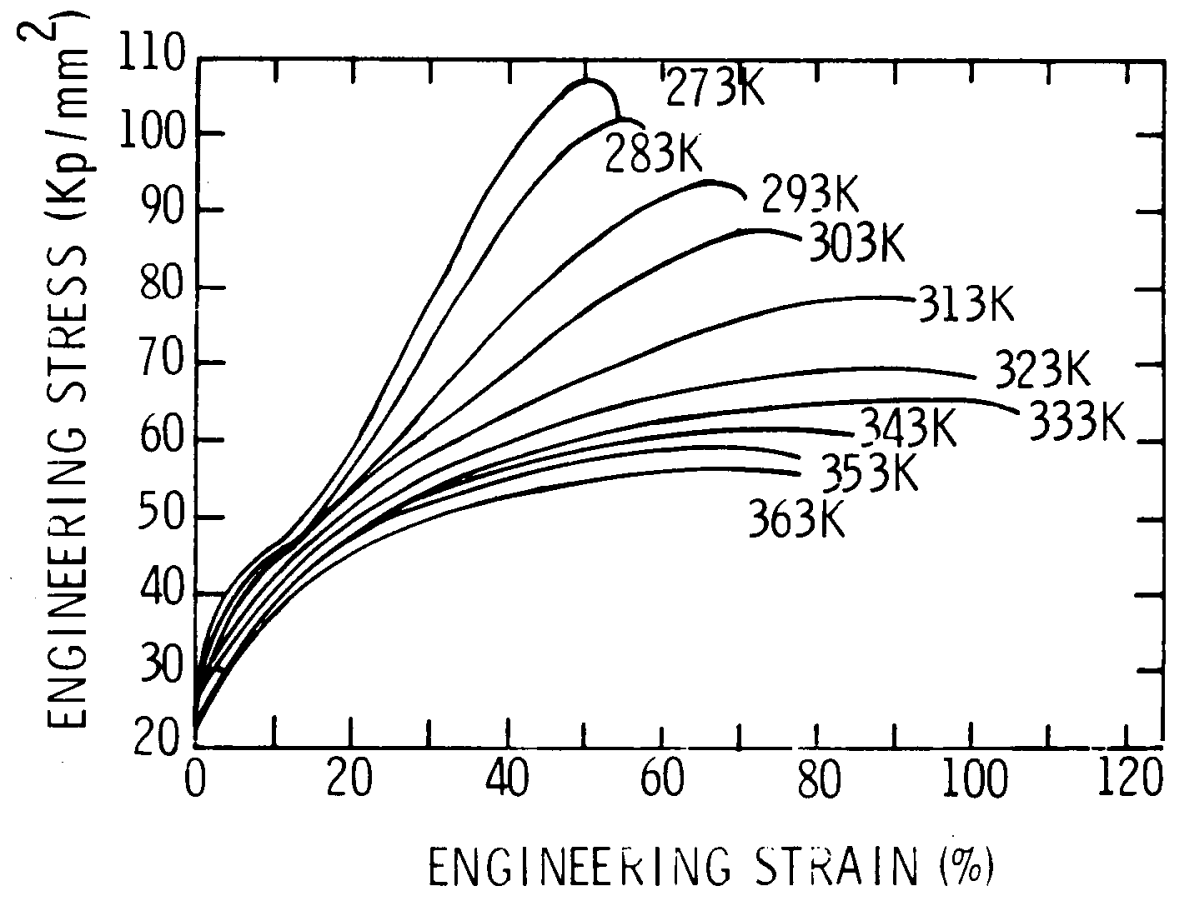

Figure 9. Engineering stress versus engineering strain for the 301 stainless steel tested at a strain rate of $1.03 \times 10^{-3} \mathrm{sec}^{-1}[5]$. 


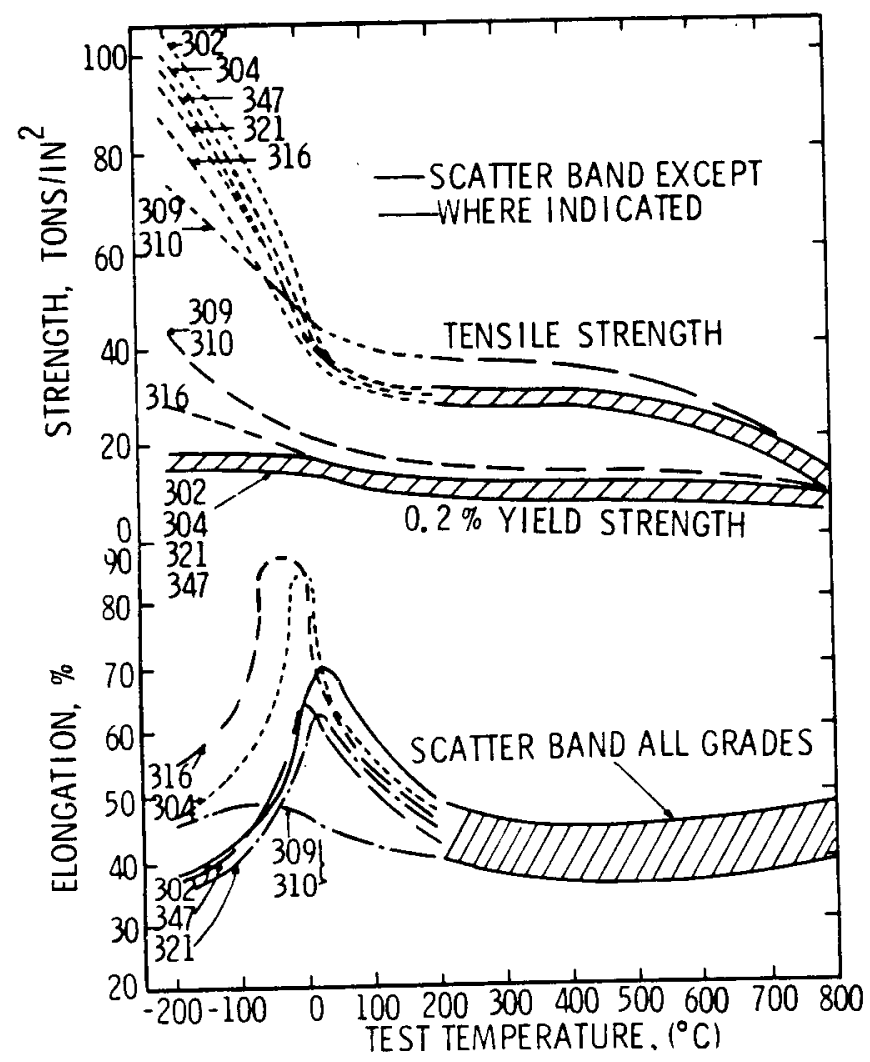

Figure 10. Tensile properties of standardgrades of austenitic steel in temperature range -200 to $+800^{\circ} \mathrm{C}[2]$.

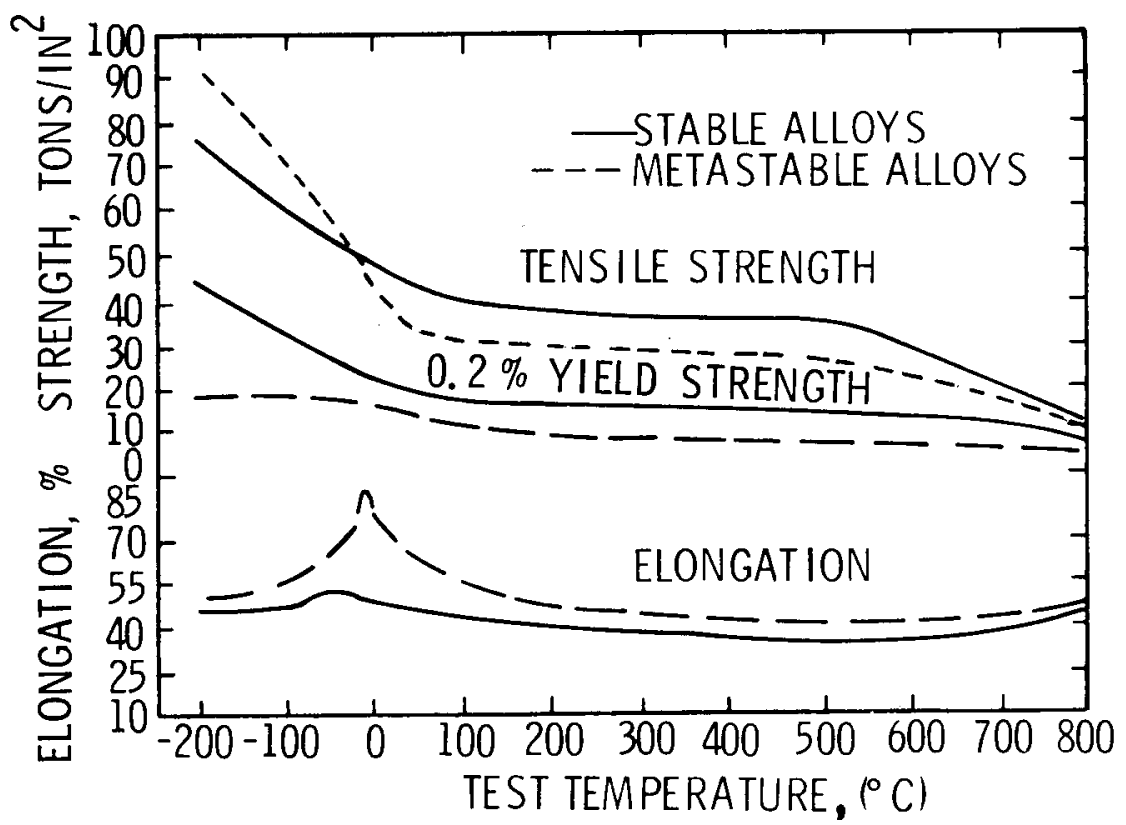

Figure 11. Effect of alloy stability on tensile properties of austenitic steels [2]. 
importance of this phenomenon cannot be quantitatively assessed at this time.

Dynamic strain-aging, the second phenomenon alluded to above, is usually associated with a change in the strain rate sensitivity (i.e., from an increase in flow stress with increasing strain rate to a decrease). Many consider strain-aging to be limited to bcc metals. There is evidence, however, that austenitic stainless steels may also exhibit dynamic strain-aging (serrations in the stress/strain curve) particularly in the temperature range 200 to $700^{\circ} \mathrm{C}$ [6]. The cross-hatched area in Figure 12 indicates the temperature and strain-rate regime within

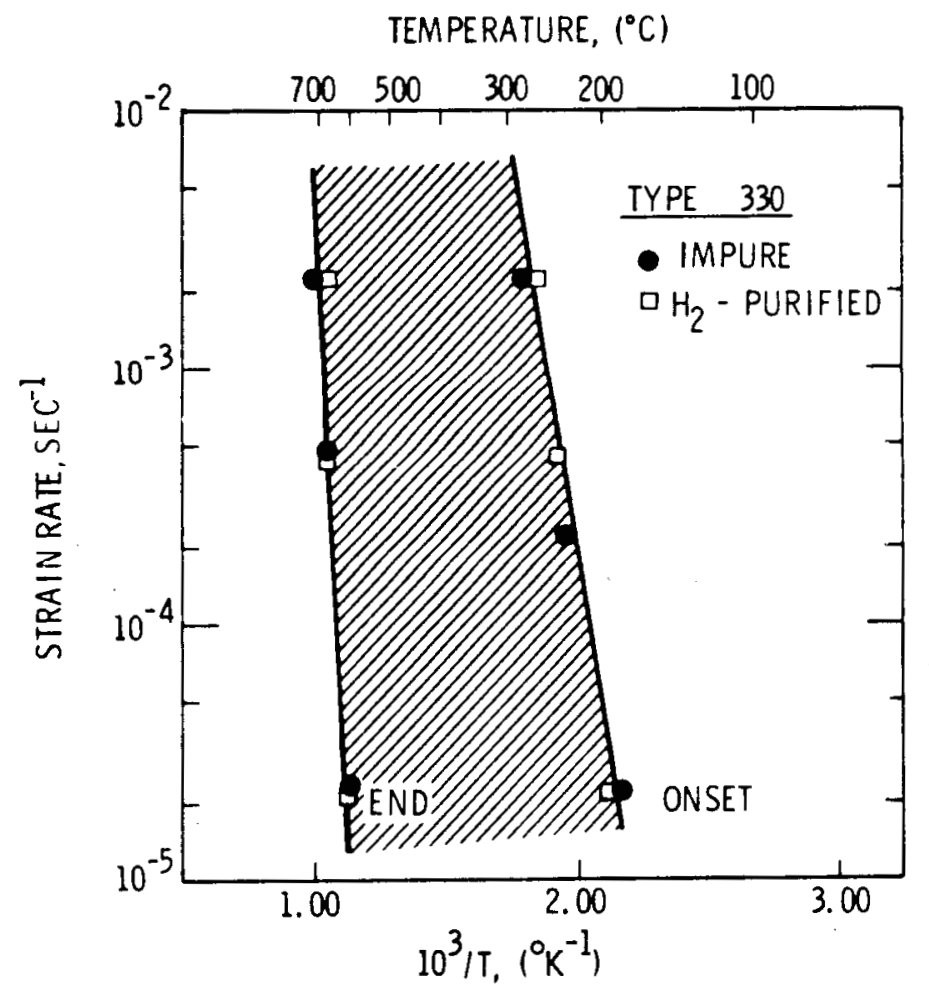

Figure 12. Relationship between strain rate and temperature for serrated flow in type 330 stainless steel [6]. 
which serrated flow is encountered in an AISI 330 stainless steel ( $\mathrm{Fe}-15 \mathrm{Cr}-35 \mathrm{Ni})$. In a more limited investigation [7], serrations have been reported in a type 316 stainless steel tested at $200^{\circ} \mathrm{C}$ utilizing a strain rate of $1.3 \times 10^{-2} \mathrm{sec}^{-1}$. These conditions correspond with those predicted from the diagram for type 330 stainless steel.

The effect of strain-aging may also be important in weld regions. Current practice involves preparation of weldments with a small percentage ( 10 percent) of body-centered cubic (bcc) ferrite. This raises the possibility that not only might dynamic strain-aging take place in the face-centered cubic (fcc) parent (base) metal but also in the partially bcc weld region, perhaps under different conditons of temperature and strain-rate.

Finally, it should be recognized that it is virtually impossible to gather enough data to describe every conceivable combination of strain-rate and temperature. For this reason, procedures for interpolation and extrapolation between a more reasonable number of data points are required. Indeed, the ideal situation would be to obtain an accurate "equation of state" which might allow one to dispense with or minimize the requirements for a data bank. Some progress has been made toward this goal [8-11]. These attempts involve parameterization of the stress/strain curves with the aim of reporting the influences of strain-rate, temperature, and material history on these characteristic functions. Some proposed equations are shown in Table V. However, these representations all suffer from a number of common difficulties. For example, none can predict the strain 


\section{TABLE V}

Typical Parametric Representations Proposed

for Austenitic Stainless Steels

$$
\sigma=\mathrm{k}_{1} \epsilon^{\mathrm{n}_{1}}+\exp \mathrm{k}_{2} \exp \mathrm{n}_{2} \epsilon
$$

$\mathrm{k}_{1}, \mathrm{n}_{1}, \mathrm{k}_{2}, \mathrm{n}_{2}$ are constants

$$
\sigma=\left(\sigma_{0}-\sigma_{\infty}\right) \exp \left(-\epsilon / \epsilon_{c}\right)+\sigma_{\infty}
$$

$\sigma_{O}, \sigma_{\infty}, \epsilon_{\mathrm{C}}$ are constants

$$
\sigma-\sigma_{\mathrm{P}}=\frac{\mathrm{CP} \epsilon}{1+\mathrm{P} \epsilon}+\dot{\mathrm{H}} \epsilon_{\mathrm{P}}
$$

$C, H, P$ are constants

$$
\epsilon_{L}=\frac{\sigma}{E}+\left[\frac{\sigma-\sigma_{P}}{K}\right]^{1 / m}
$$

$\mathrm{K}, \mathrm{m}$ are constants

See Appendix $C$ for the definition of all other symbols. 
at fracture. Furthermore, phenomena such as strain-aging or martensite formation are not presently amenable to analysis.

\section{Uranium}

The choice of uranium or dilute uranium alloys for nuclear shielding applications is principally predicated on their high density $\left(18.9 \mathrm{gm} / \mathrm{cm}^{3}\right)$ and atomic number. Some authors [15] suggest that these materials may be considered structurally equivalent to mild steel. However, this assumption is generally unfounded and is extremely misleading.

Pure uranium undergoes three phase changes between $-40^{\circ} \mathrm{C}$ and its melting point. Between -40 and $633^{\circ} \mathrm{C}$, the temperature region of primary interest in this examination, its crystal structure is orthorhombic. Between 663 and $700^{\circ} \mathrm{C}$ it has a complex tetragonal structure, and above $770^{\circ} \mathrm{C}$ it undergoes a transition to body centered cubic.

The orthorhombic crystal structure of the alpha (or low temperature) phase suggests that the mechanical and physical properties of uranium will be highly anisotropic. For example, Appendix A shows that the thermal expansion behavior of single crystal $\alpha$-uranium, may vary by a factor of 5 , depending upon the particular crystallographic direction being considered. Practically, this large anisotropy in thermal expansion results in some grains being stressed beyond yield upon cooling. Subsequent application of a load will then result in plastic flow at vanishingly small stresses $[16,17]$. 
Another complication which arises because of the anisotropic nature of $\alpha$-uranium is that both its elastic and plastic properties (e.g., strain hardening behavior) are dependent upon prior processing history. Highly textured material, where nearly all of the elastically "strong" directions are aligned, shows a twofold difference in elastic modulus between the "strong" and "weak" directions (see Appendix B). Few previous investigators have measured or even considered this textural effect when discussing the plastic deformation of uranium. This fact makes direct comparisons between various studies difficult and may explain some of the scatter observed.

The mechanical properties of depleted $\alpha$-uranium are also quite sensitive to temperature (Figure 13). Decreasing the test temperature from $663^{\circ} \mathrm{C}$ results in an increase in tensile yield and ultimate strength. This increase is accompanied (to approximately $350^{\circ} \mathrm{C}$ ) by a decrease in tensile ductility. Between 350 and $25^{\circ} \mathrm{C}$ the ductility appears to be essentially independent of temperature, or may exhibit a slight minima. Finally, below $25^{\circ} \mathrm{C}$ the ductility decreases sharply (i.e., $\alpha$-uranium undergoes a ductile-brittle transition at about $25^{\circ} \mathrm{C}$ ). These ductility changes have been associated with fracture transitions from ductile failure, involving inclusions $[18,19]$, to mixed ductile plus intergranular failure and, finally, to twin-matrix [19] cleavage failure at the lowest test temperature.

The ranges over which the differing temperature-ductility relationships are observed can be altered in addition by changing test conditions, $\alpha$-uranium microstructure, chemistry, etc. The 


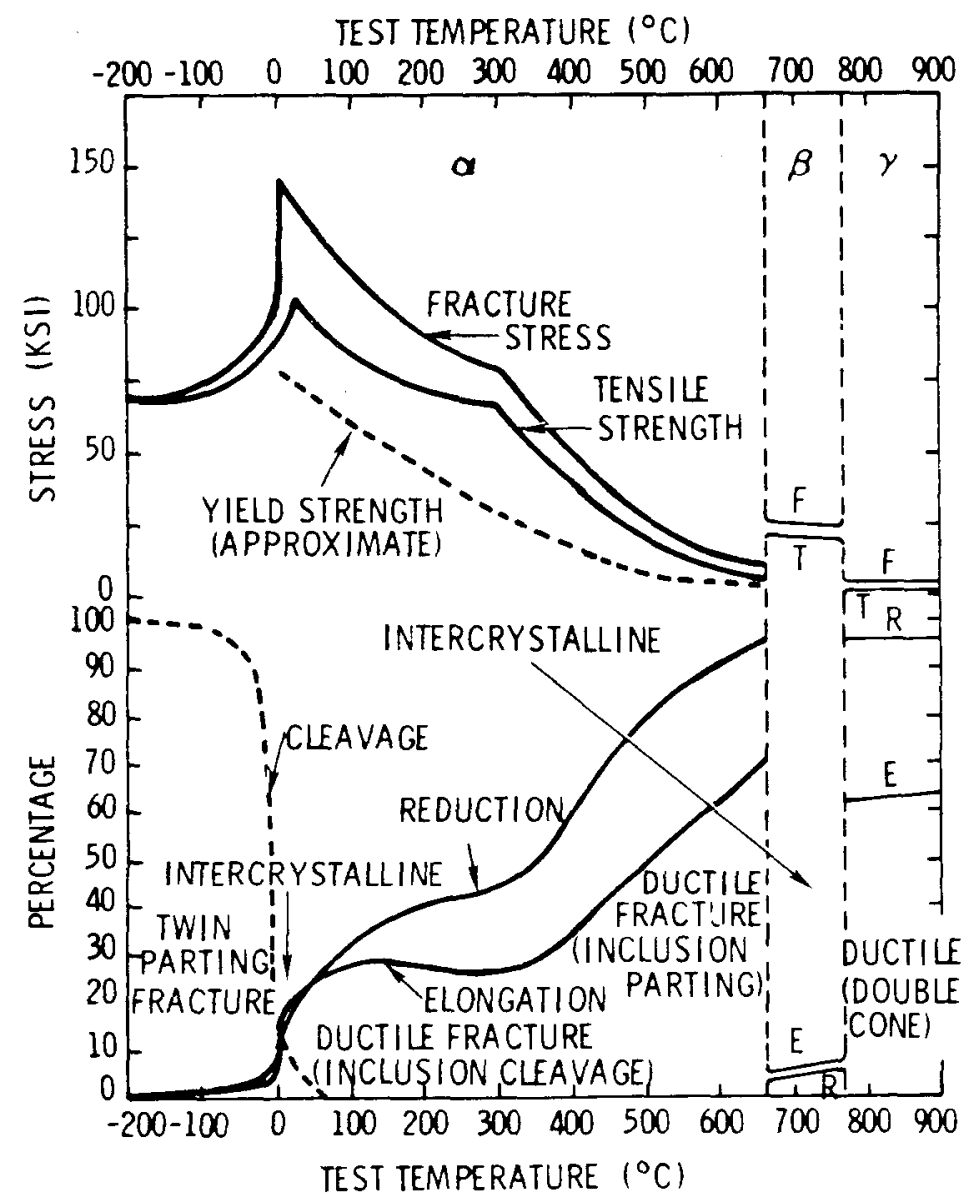

Figure 13. The effect of test temperature $\left(-200^{\circ} \mathrm{C}\right.$ to $\left.+900^{\circ} \mathrm{C}\right)$ on the tensile properties and fracture of uranium [18].

ductile-brittle transition temperature has been found to increase with increasing strain rate $[21,22]$, grain size $[17,18]$, grain shape irregularity $[23,24]$, internal hydrogen content $[22,25-$ 29], iron and aluminum content [24], residual stress level [30], humidity [31-33], and decreasing amounts of prior strain [17,34, 35]. The effect of one of these variables, grain size, on the transition temperature is shown in Figure 14. A quantitative assessment of the other variables awaits more detailed experimental studies. 


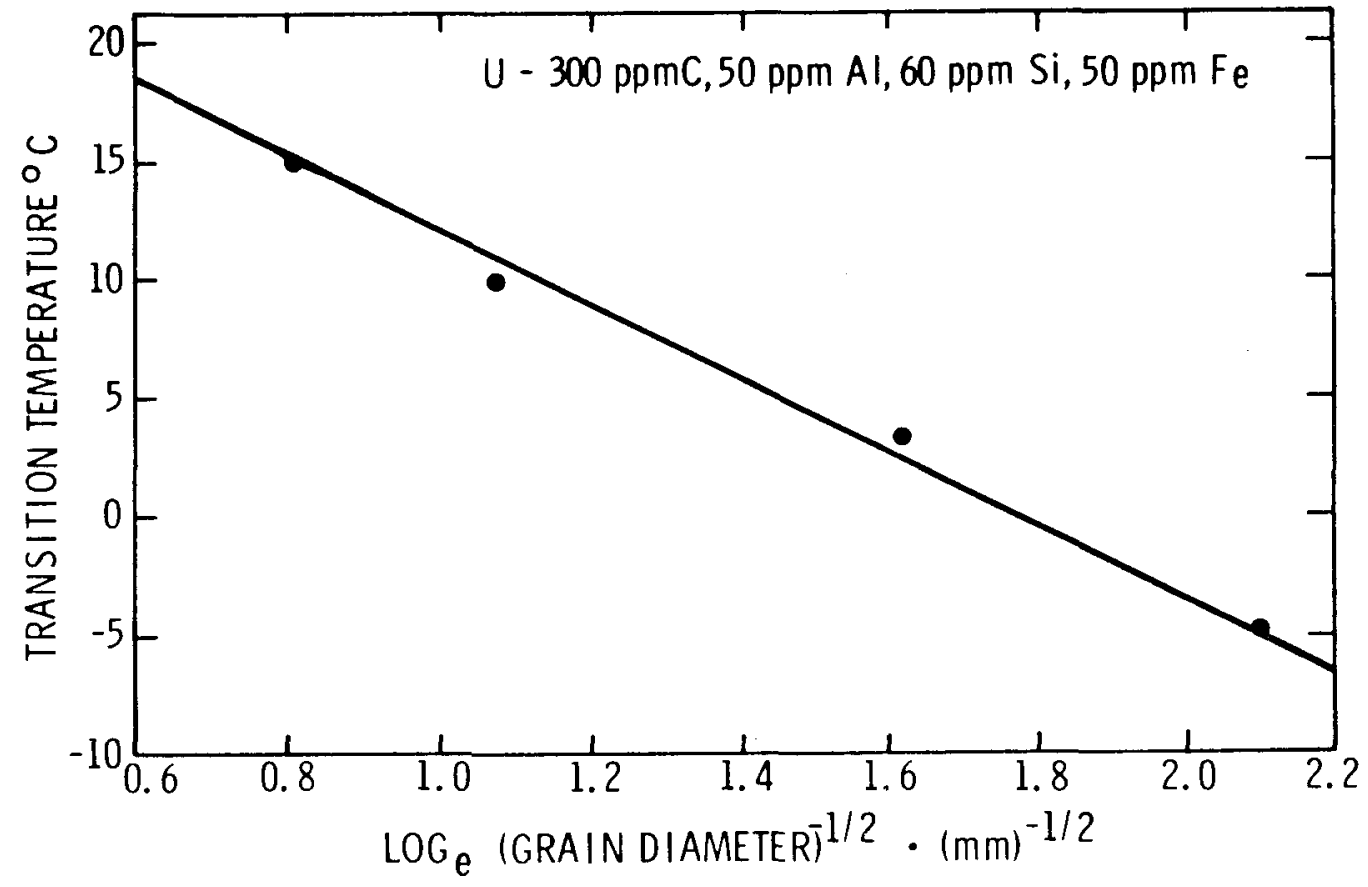

Figure 14. Ductile/brittle transition temperature versus $\log _{e}$ (grain diameter) $-1 / 2$ for $\mathrm{U}-300 \mathrm{ppm} \mathrm{C}, 50 \mathrm{ppm} \mathrm{Al,} 60 \mathrm{ppm} \mathrm{Si}$, and 50 ppm Fe [3].

In a similar fashion, the ductility above the ductilebrittle transition region may be decreased by decreasing purity [36] and increasing residual stress $[36,37]$. Differences in residual stress level may also affect the strain hardening behavior of $\alpha$-uranium. Figure $15(a)$ shows a family of serrated load-elongation curves of $\alpha$-uranium in which the samples have had a high residual stress level induced in them by quenching from elevated temperature. If the same material had been furnace cooled, serrated yielding behavior would not have been observed (Figure 15(b)). The residual stress levels associated with these two heat treatment procedures were not reported so that our understanding of the influence of residual stress on the 

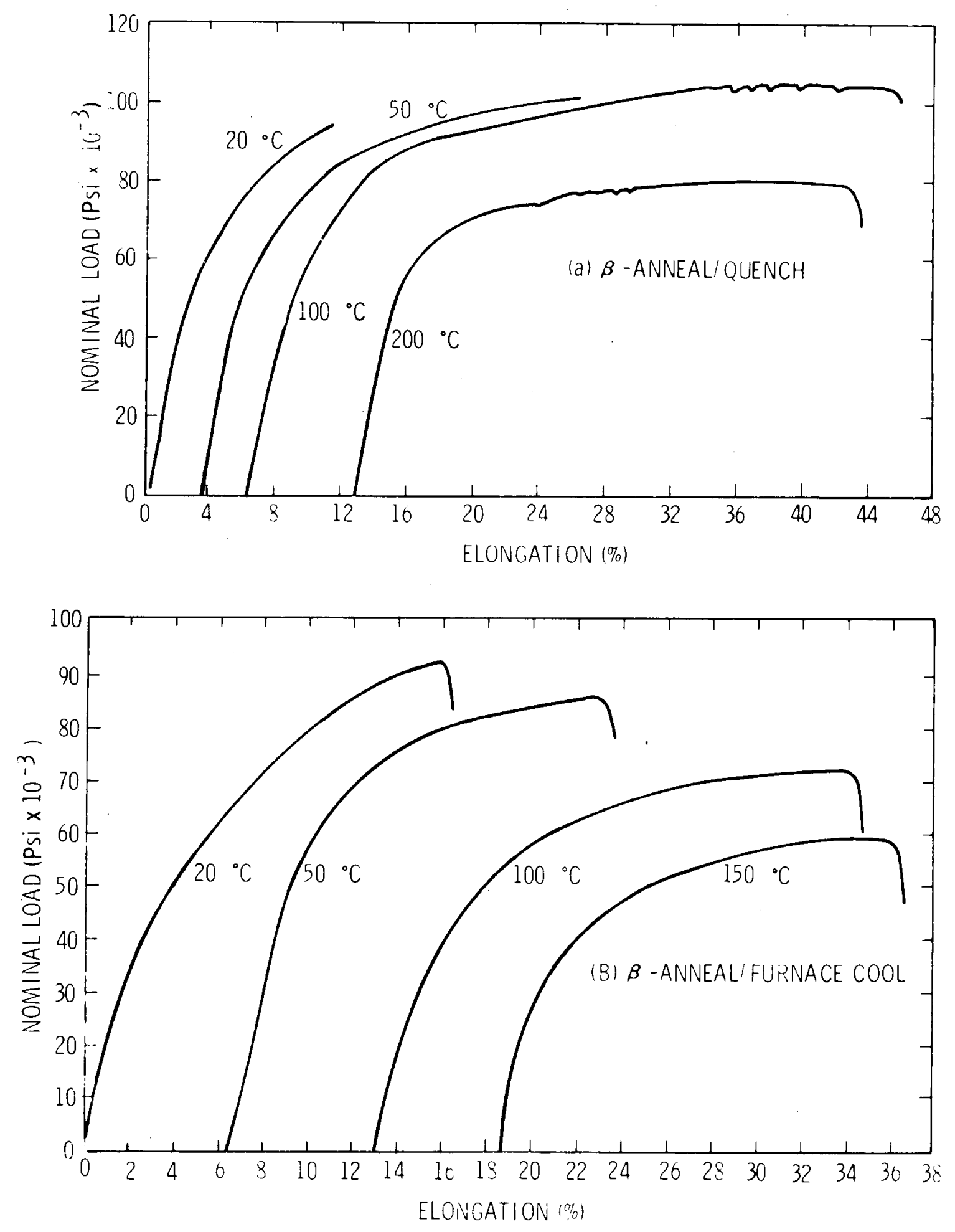

Figure 15. Load-elongation curves of $\alpha$-uranium (U - 140 ppm C, $30 \mathrm{ppm} \mathrm{Al}, 140 \mathrm{ppm} \mathrm{Fe}, 60 \mathrm{ppm} \mathrm{Si,} 40 \mathrm{ppm} \mathrm{O}_{2}$ ). Strain rate $2.6 \times 10^{-4} \mathrm{sec}^{-1}$ [37]. 
tensile ductility in the temperature region 50 to $350^{\circ} \mathrm{C}$ remains qualitative. The same situation exists with regard to the impurity effects since no quantitative examination has been reported.

Finally, Figures 16 and 17 represent a summary of the presently available stress-strain curves for $\alpha$-uranium. It should be recognized that neither of these series is for as-cast $\alpha-$ uranium; to date attempts to locate same have been unsuccessful. Notwithstanding this, it appears that the changes in strain hardening behavior that would be anticipated by increasing strain

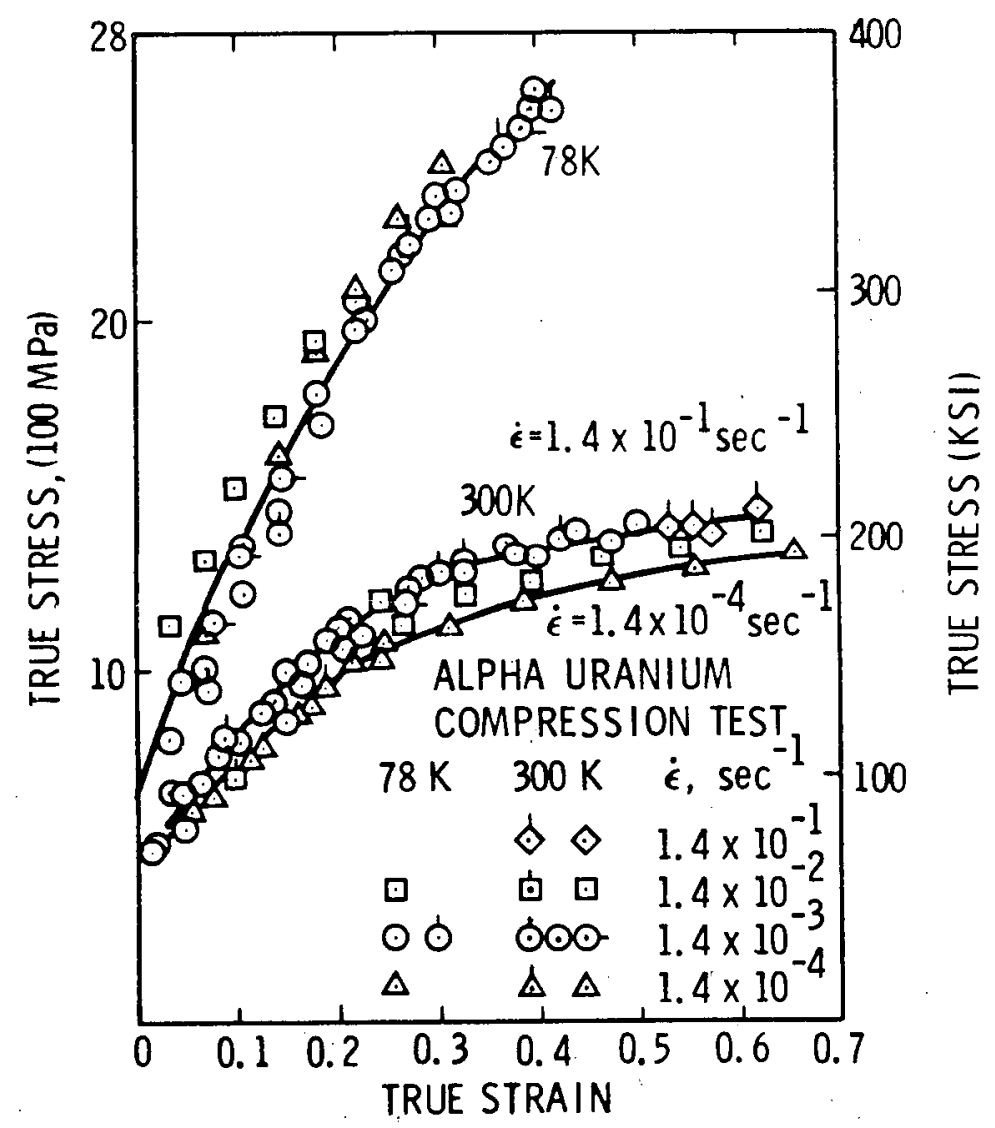

Figure 16. Influence of strain rate on the true-stress versus true-strain curves of annealed polycrystalline $\alpha$-uranium (110 ppm C, $35 \mathrm{ppm} \mathrm{Al,} 70 \mathrm{ppm} S \mathrm{i}, 15 \mathrm{ppm}$ $\mathrm{Cr}, 8 \mathrm{ppm} \mathrm{Mo}, 60 \mathrm{ppm} \mathrm{Fe}, 40 \mathrm{ppm} \mathrm{Ni}, 6 \mathrm{ppm} \mathrm{Cu})$ at 78 and $300 \mathrm{~K}\left(-195\right.$ and $\left.27^{\circ} \mathrm{C}\right)[38]$. 

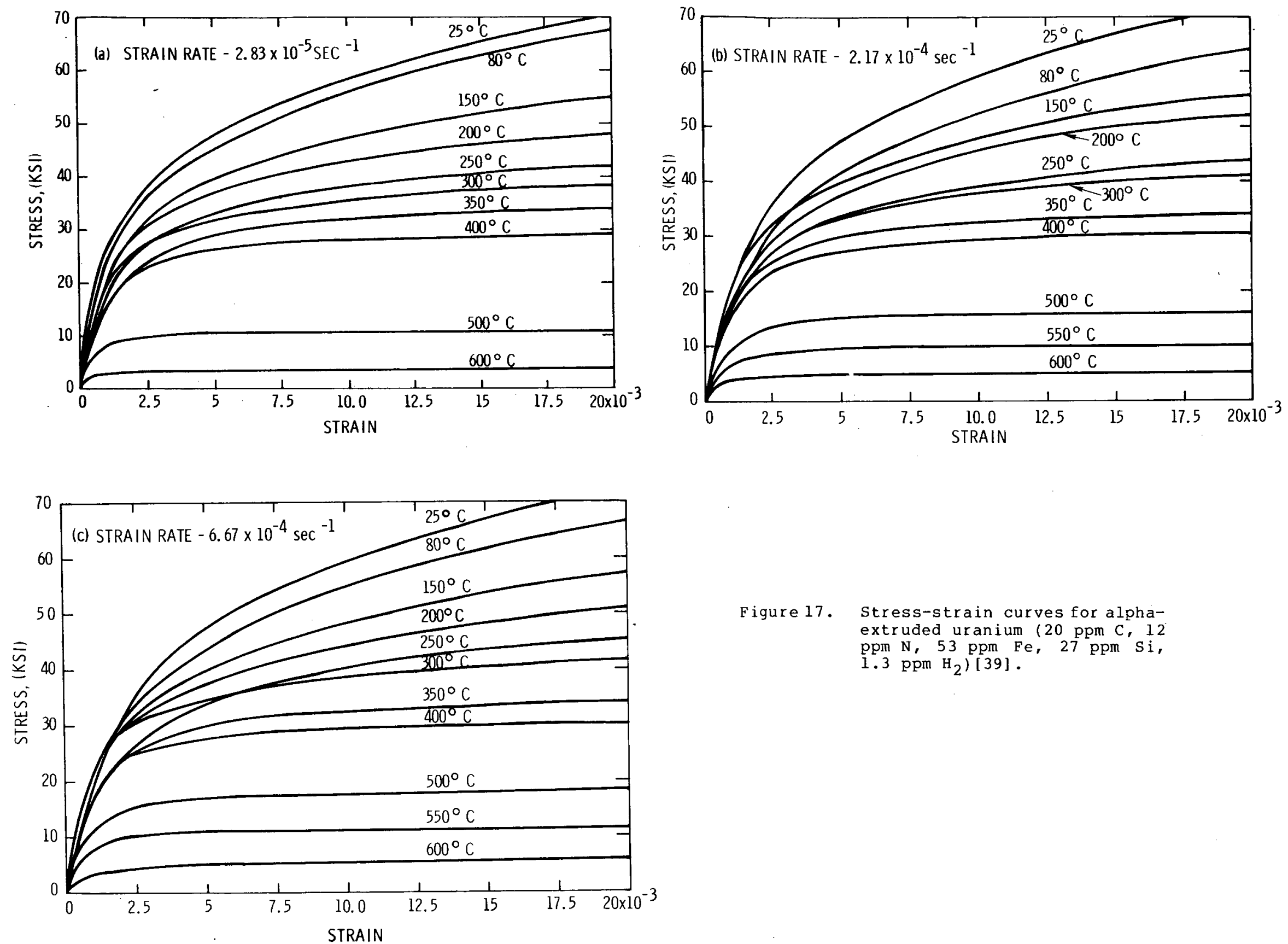

Fiqure 17. Stress-strain curves for alphaextruded uranium (20 ppm C, 12 ppm N, $53 \mathrm{ppm} \mathrm{Fe}, 27 \mathrm{ppm}$ 'Si, $\left.1.3 \mathrm{ppm} \mathrm{H}_{2}\right)[39]$. 
rate appear quite small and that the changes in flow stress and strain hardening behavior with changing temperature appear to be of paramount importance.

These results all suggest that depleted $\alpha$-uranium should not at present be considered as a primary structural member since it undergoes a sharp loss in ductility with decreasing temperature. However, there is some evidence which suggests that appropriately heat treated uranium alloys (e.g., U-2 wto Mo) may have a ductile-brittle transition temperature well below that of $\alpha$-uranium (compare Figures 13 and 18).

\section{$\underline{\text { Lead }}$}

A review of those physical, chemical, and mechanical characteristics of lead which have resulted in its widespread use for nuclear shielding has been given by stukenbroeker et al. [40]. Paramount among these is lead's high density $\left(\rho_{293 \mathrm{~K}}=11.35 \mathrm{gm} /\right.$ $\mathrm{cm}^{3}$ ), low cost, and relative ease of fabrication. Although the present examination is 1 imited to "chemical" lead, various other lead purities and alloys may be selected for nuclear applications. The terminology "chemical" lead is generally restricted to material as specified by ASTM B29-55. Table I shows the standard chemical specification for this grade of pig lead, silver and copper being the principal impurities. Consideration of the $\mathrm{Pb}-\mathrm{Ag}$ and $\mathrm{Pb}-\mathrm{Cu}$ binary phase diagrams (Figure 19) suggests that while the Ag impurity concentration lies within the expected range of solid solubility, the presence of 0.04 to 0.08 weight percent copper will result in the formation of a two-phase 

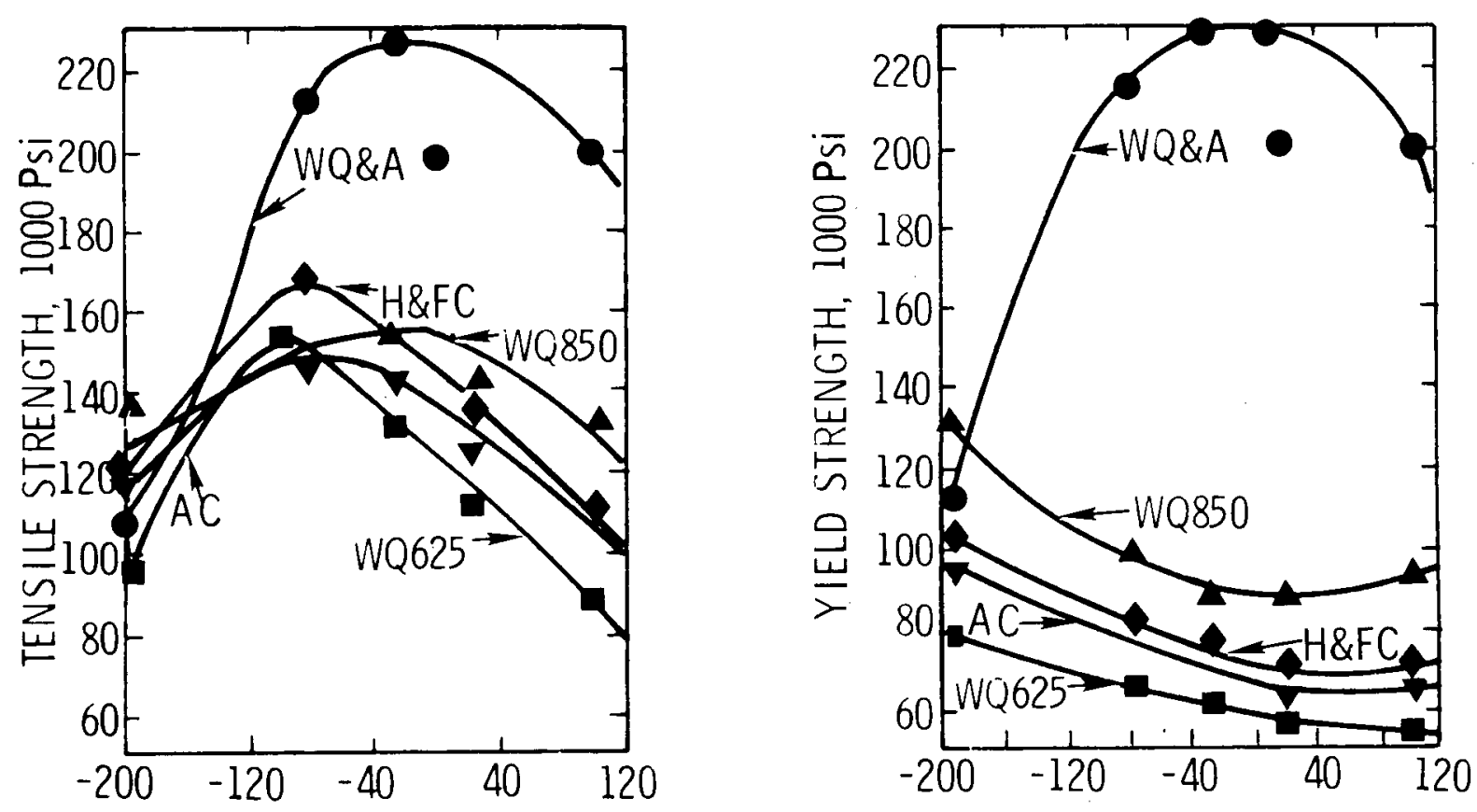

TESTING TEMPERATURE ${ }^{\circ} \mathrm{C}$
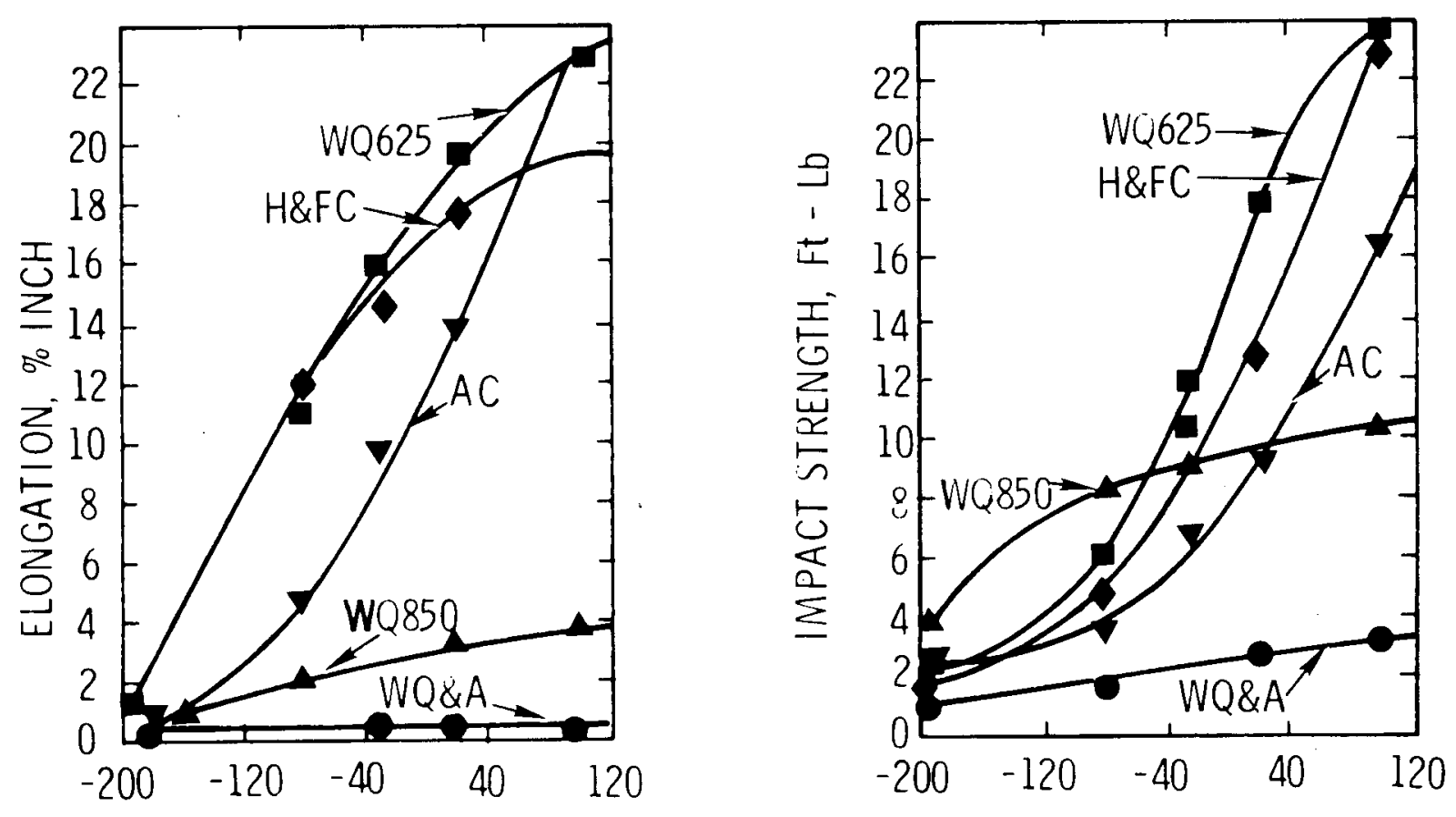

TESTING TERMPERATURE ${ }^{\circ} \mathrm{C}$

Figure 18. Mechanical properties of uranium-2 weight percent Mo (WQ\&A: Water Quench and AGe; H\&FC: Homogenize and Furnace Cool; AC: Air Cool)[20]. 
rate appear quite small and that the changes in flow stress and strain hardening behavior with changing temperature appear to be of paramount importance.

These results all suggest that depleted $\alpha$-uranium should not at present be considered as a primary structural member since it undergoes a sharp loss in ductility with decreasing temperature. However, there is some evidence which suggests that appropriately heat treated uranium alloys (e.g., U-2 wto Mo) may have a ductile-brittle transition temperature well below that of $\alpha$-uranium (compare Figures 13 and 18).

\section{Lead}

A review of those physical, chemical, and mechanical characteristics of lead which have resulted in its widespread use for nuclear shielding has been given by stukenbroeker et al. [40] . Paramount among these is lead's high density $\left(\rho_{293 \mathrm{~K}}=11.35 \mathrm{gm} /\right.$ $\mathrm{cm}^{3}$ ), low cost, and relative ease of fabrication. Although the present examination is limited to "chemical" lead, various other lead purities and alloys may be selected for nuclear applications.

The terminology "chemical" lead is generally restricted to material as specified by ASTM B29-55. Table I shows the standard chemical specification for this grade of pig lead, silver and copper being the principal impurities. Consideration of the $\mathrm{Pb}-\mathrm{Ag}$ and $\mathrm{Pb}-\mathrm{Cu}$ binary phase diagrams (Figure 19) suggests that while the Ag impurity concentration lies within the expected range of solid solubility, the presence of 0.04 to 0.08 weight percent copper will result in the formation of a two-phase 

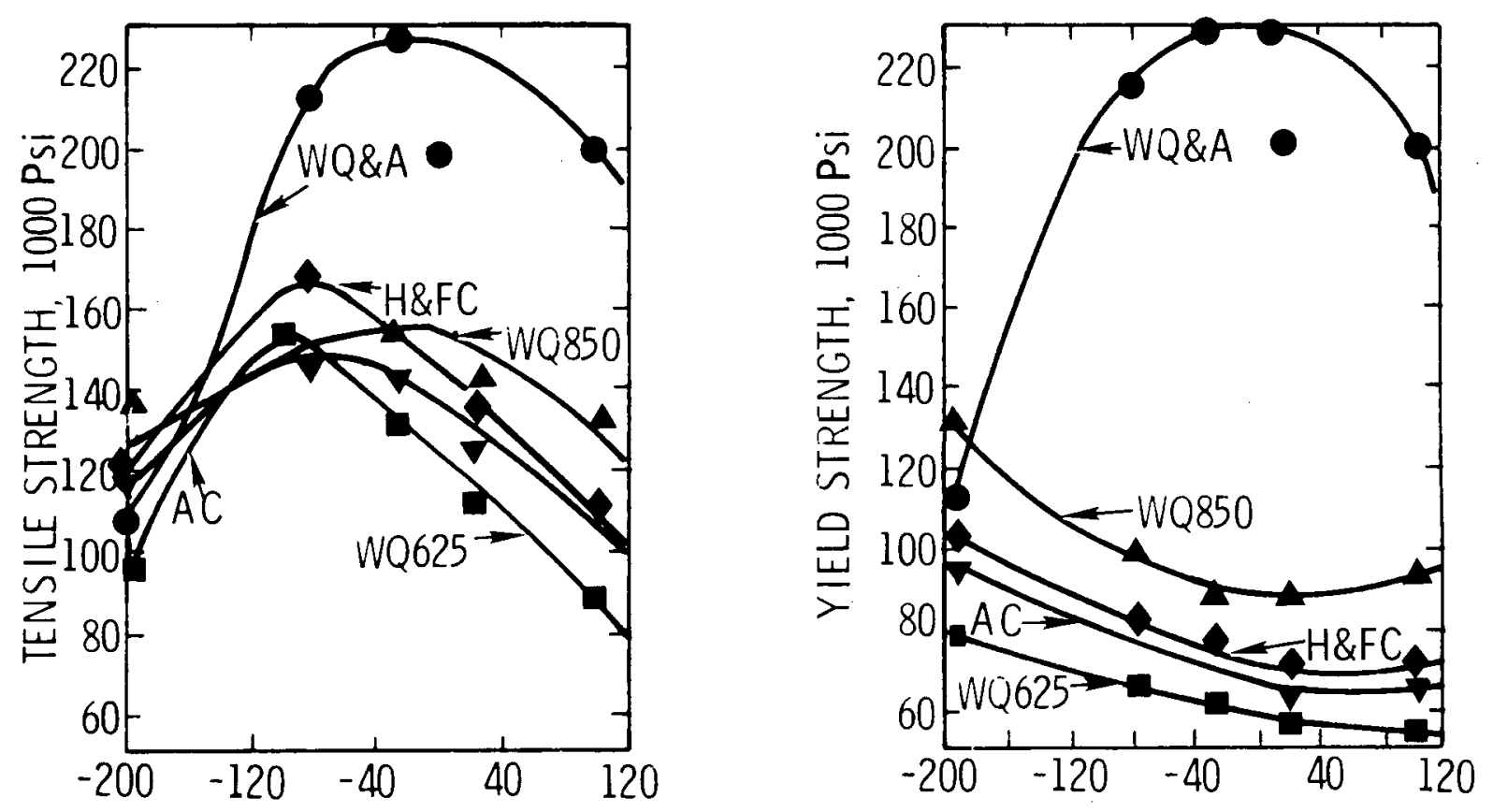

TESTING TEMPERATURE ${ }^{\circ} \mathrm{C}$
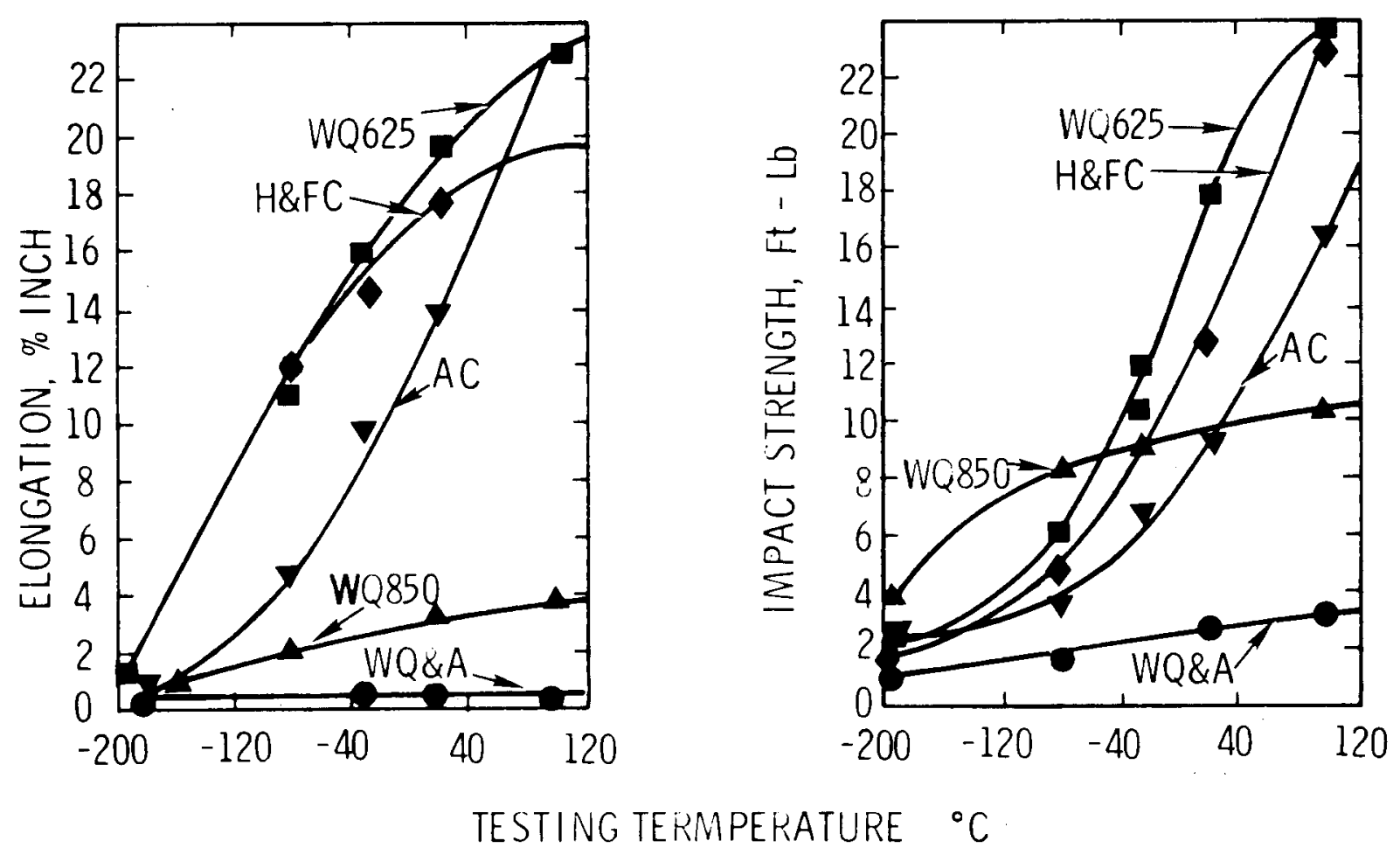

Figure 18. Mechanical properties of uranium-2 weight percent Mo (WQ\&A: Water Quench and AGe; H\&FC: Homogenize and Furnace Cool; AC: Air Cool)[20]. 


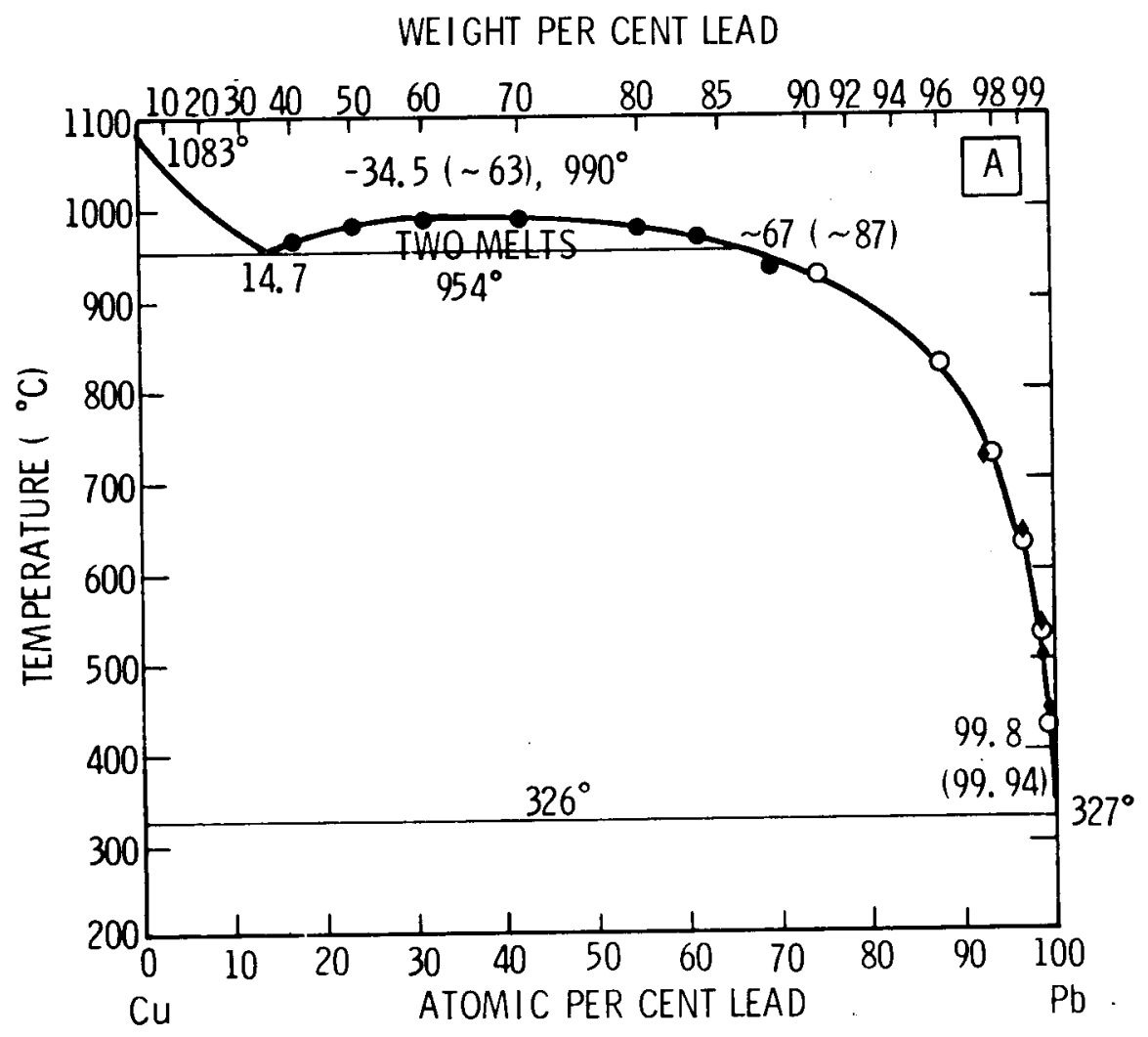

WEIGHT PER CENT LEAD

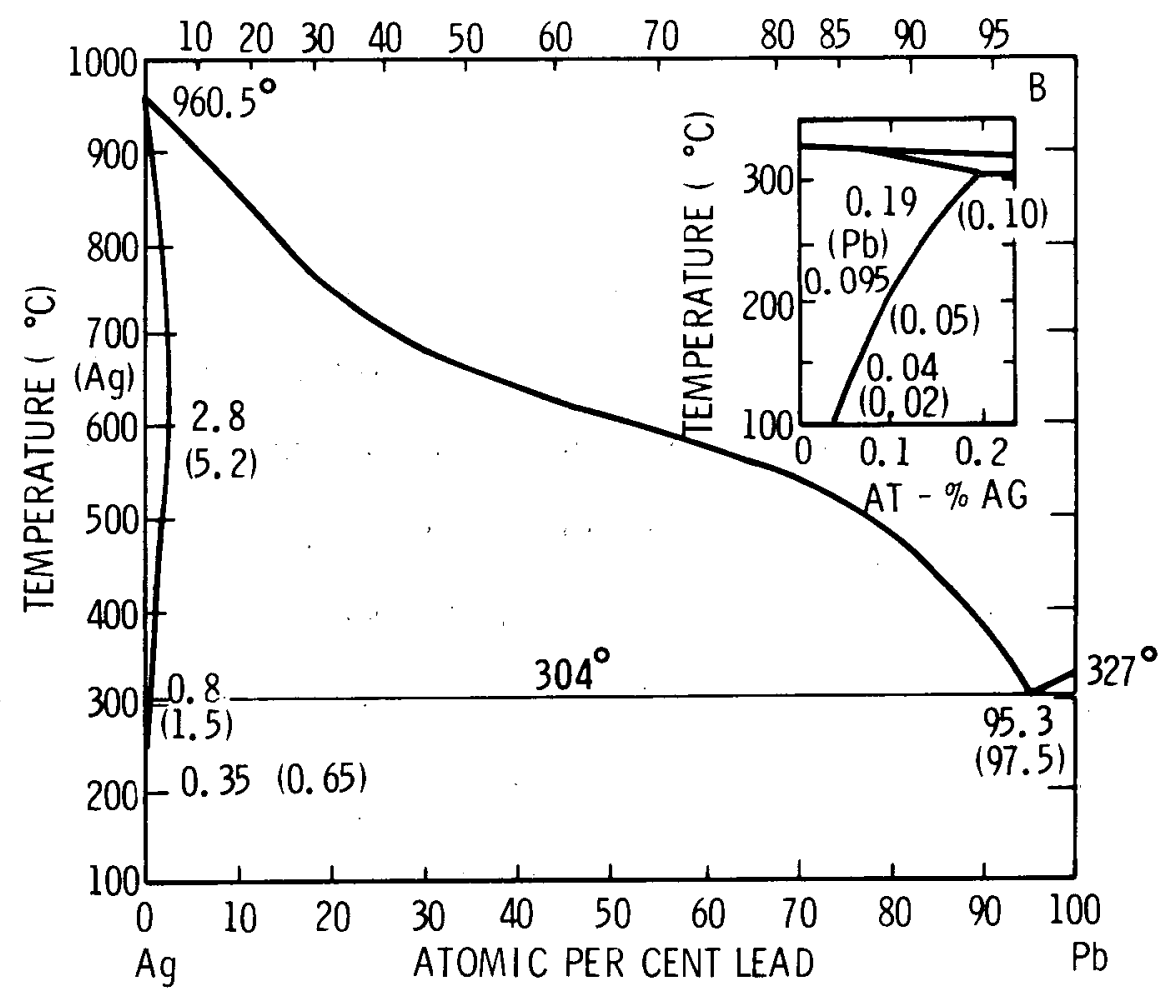

Figure 19. Phase diagrams for (a) copper-lead and (b) silver-lead [41]. 
$(\mathrm{Cu}+\mathrm{Pb})$ alloy. It is, therefore, not surprising that this small amount of copper has been reported to have a noticeable effect on the mechanical properties of lead.

Although there have been a number of examinations of the influence of strain-rate and temperature on the mechanical behavior of lead $[42,56]$, application of these data to shipping cask environments is not straightforward. In general, the available data do not include a description of either the chemistry or thermomechanical condition for the material being examined. Under these circumstances probably the most complete series of experiments that have been performed to date are those of Tietz [51] (Figure 20 through 23) and Green et al. [56] (Figures 24 and 25). The former author's results demonstrate that the mechanical behavior of lead is quite sensitive to chemistry. Indeed, at low temperatures high purity (99.995 percent) lead is stronger than lead containing 0.058 weight percent $\mathrm{Cu}$, contrary to what might be expected while at temperatures above $373 \mathrm{~K}\left(100^{\circ} \mathrm{C}\right)$, the opposite trend is observed (Figure 26). It is also interesting to note that the more recent results of Evans [45] (Figures 27 and 28) do not agree with those of Tietz. Presently, the cause of this discrepancy is undefinable, since Evans simply reported his material as "chemical" lead without giving any information as to the actual chemistry, grain structure, etc.

One final comment must be made regarding mechanical property reproducibility at high-strain rates. Generally the observed measurement errors are large and, more importantly, are unpredictable. For example, the undulations observed in the 

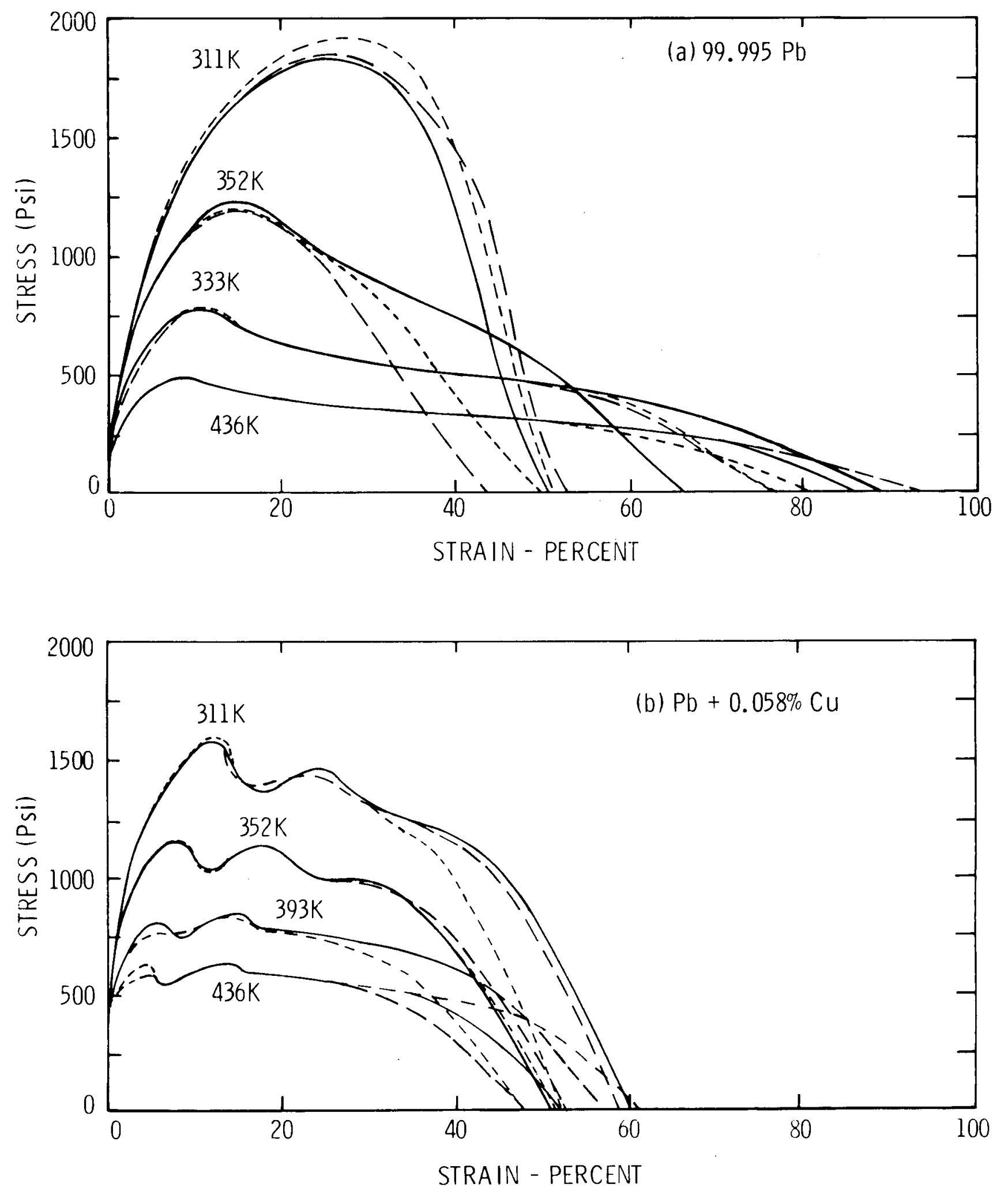

Figure 20. Triplicate tensile stress-strain curves to failure at a strain rate of $1 \times 10^{-3} \mathrm{sec}^{-1}$ [51]. 

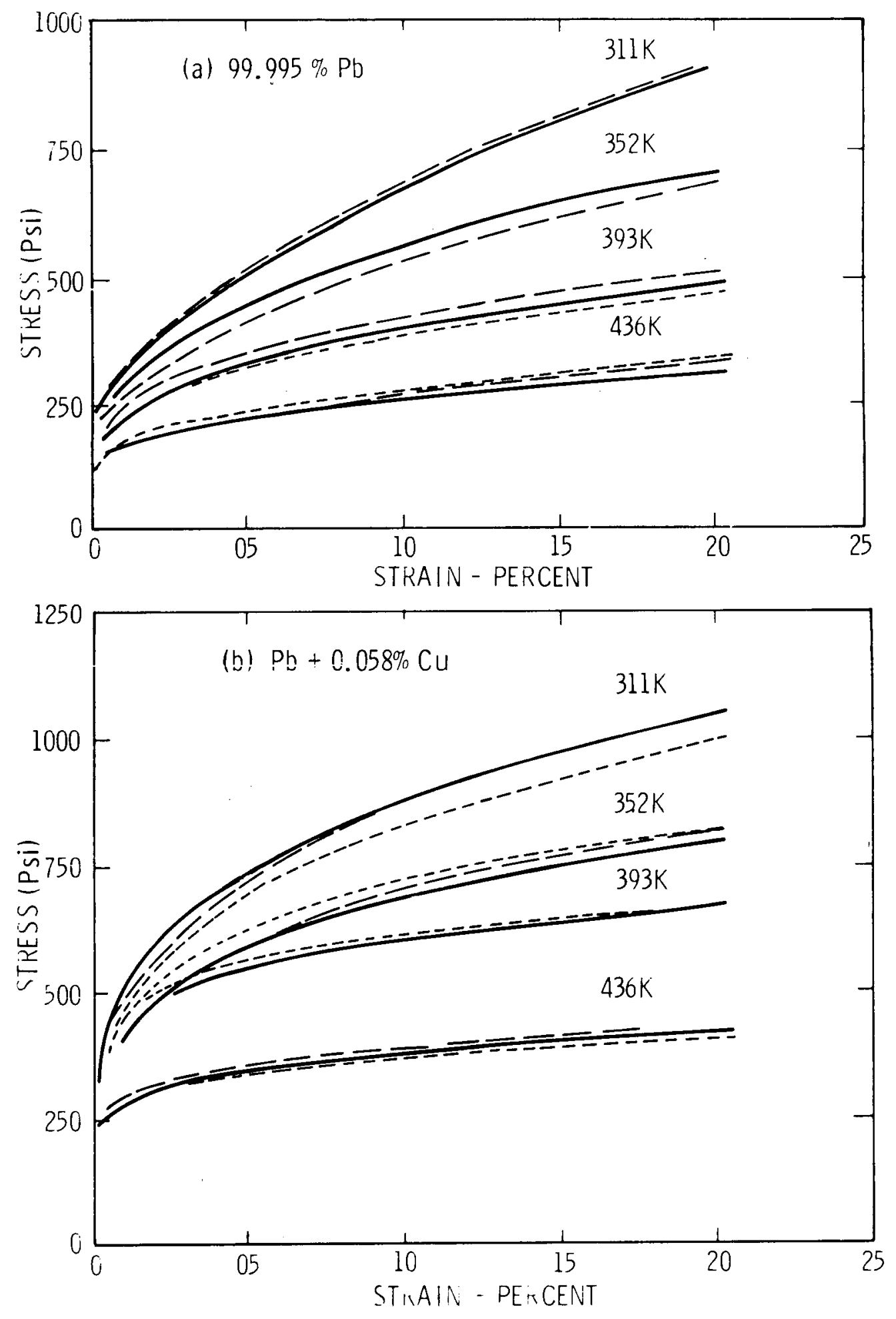

Figure 21. Triplicate tensile stress-strain curves to 2 percent strain at a strain rate of $8.3 \times 10^{-5} \mathrm{sec}^{-1}$ [51]. 

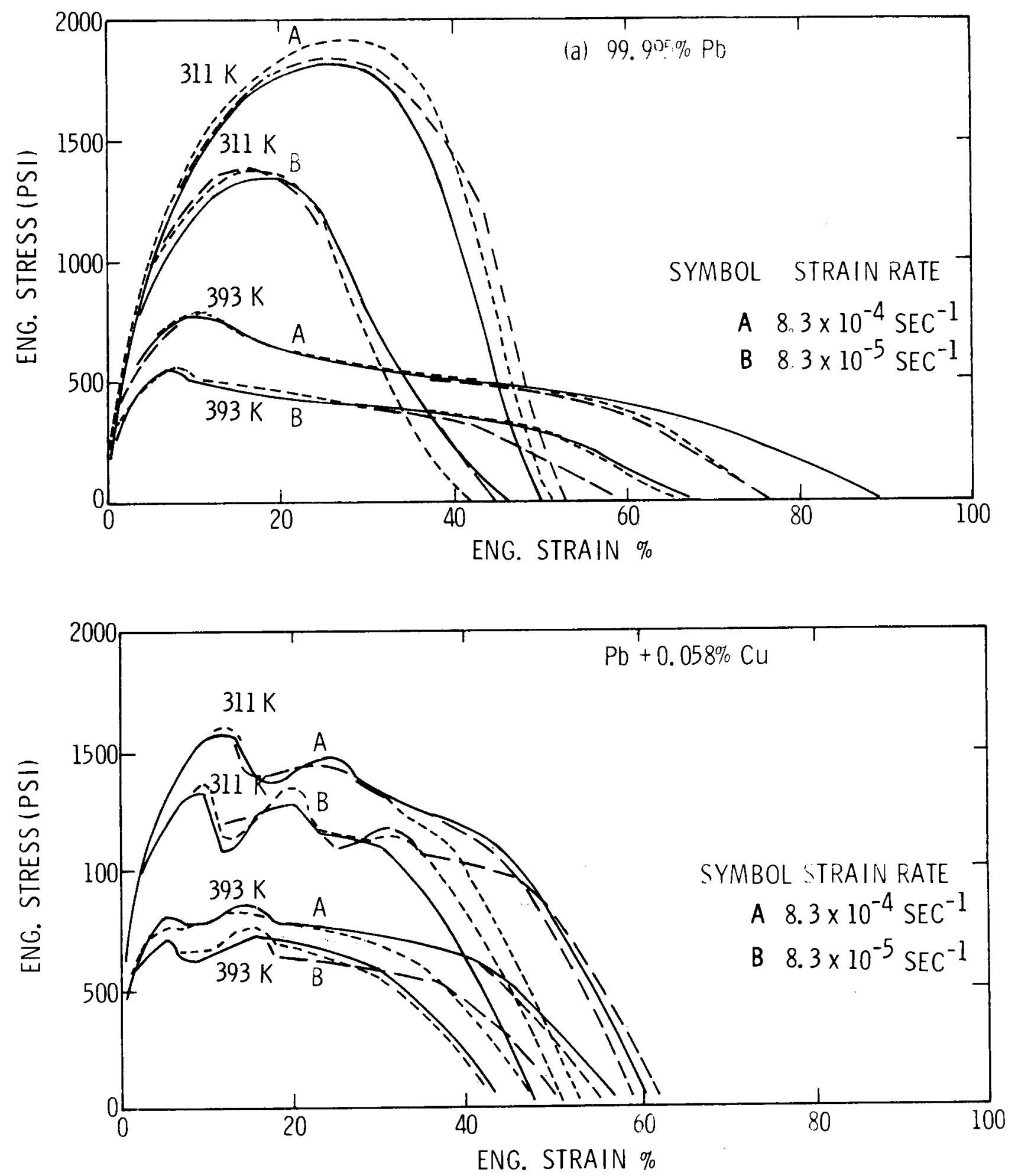

Figure 22. Effect of strain rate on the tensile stress-strain curves at 311 and $393 \mathrm{~K}$ (triplicate curves) [51]. 

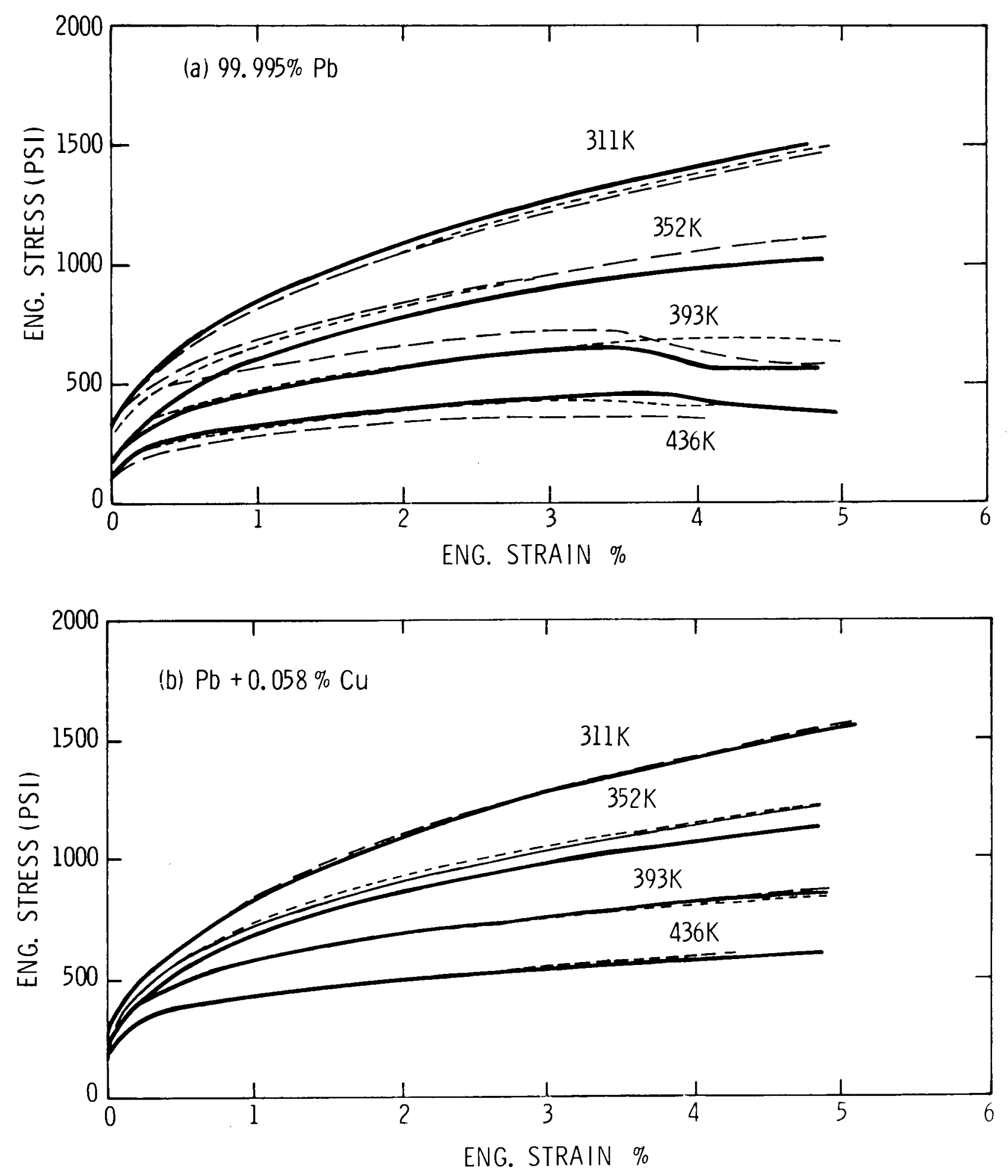

Figure 23. Triplicate compression stress-strain curves to 5
percent strain at a strain rate of $2.5 \mathrm{x} 10^{-4}$ $\sec ^{-1}[51]$. 


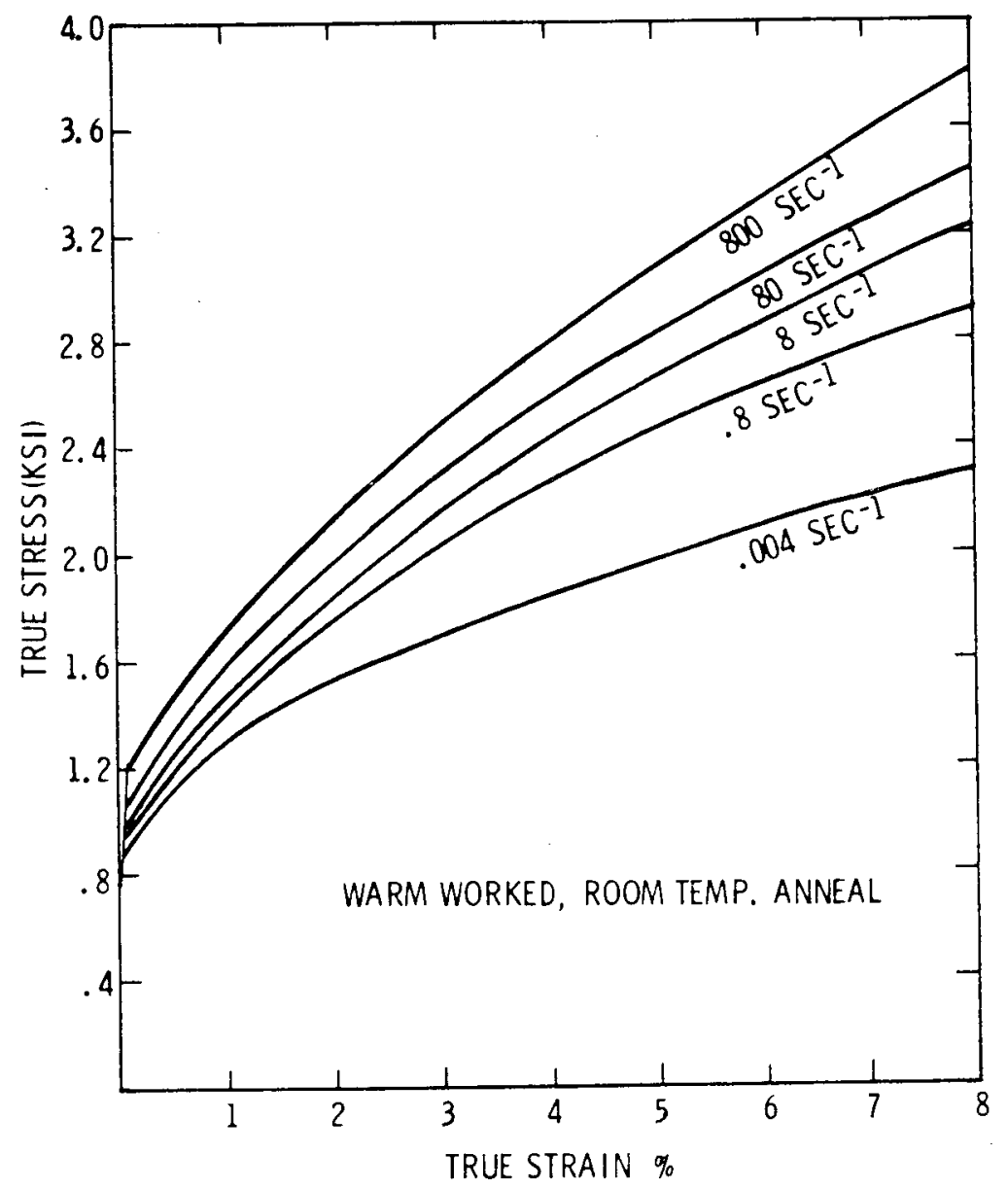

Figure 24. Stress-strain curves for $\mathrm{Pb}$ [56].

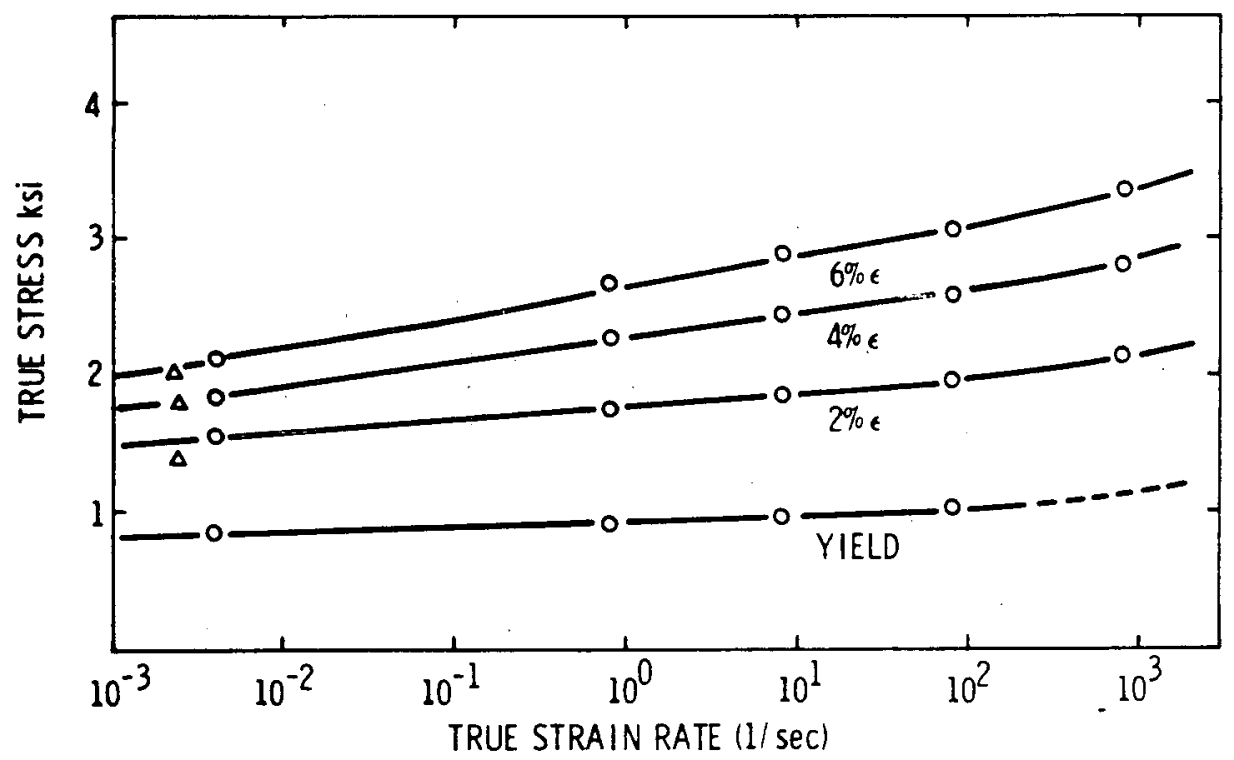

Figure 25. Influence of strain rate on flow stress of $\mathrm{Pb}$ [56]. 


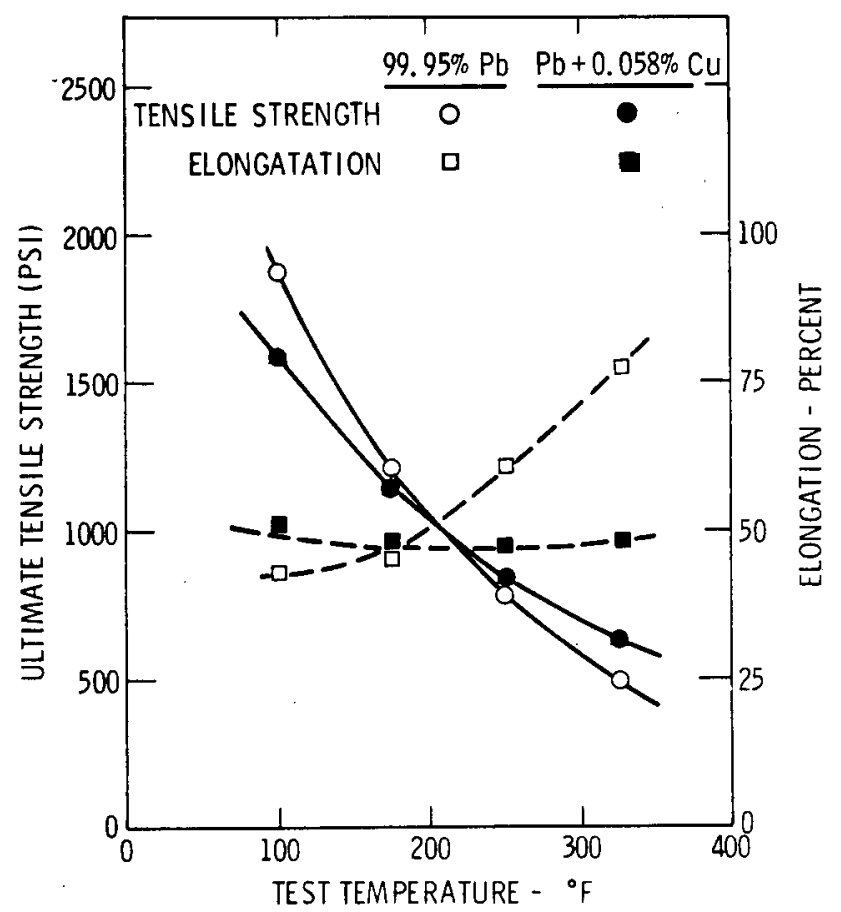

Figure 26. Tensile strength and elongation as a function of test temperature

[51].

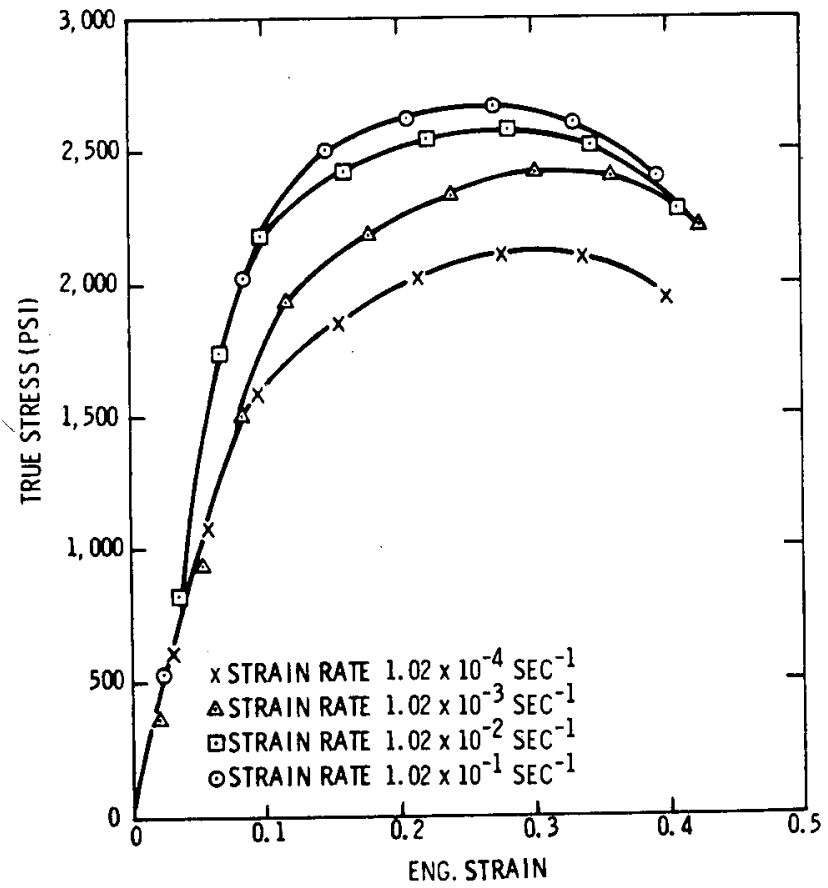

Figure 27. Quasi-static true stress-strain curves for chemical lead test specimens in tension [45].

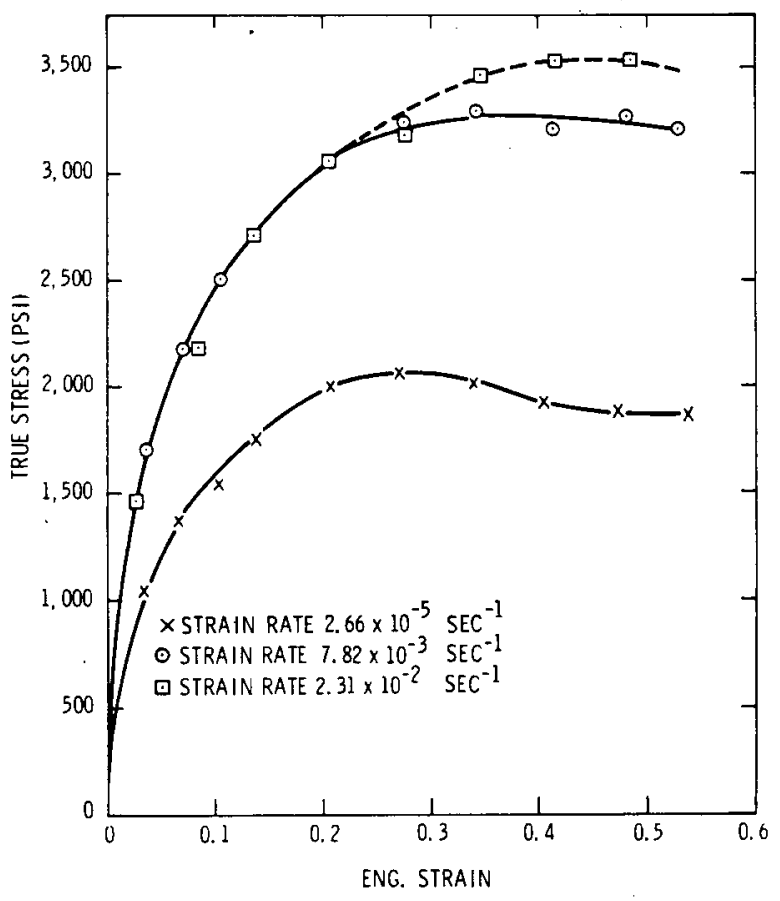

Figure 28. Quasi-static true stress-strain curves for chemical lead test specimens in compression [45]. 
stress-strain curves shown in Figure 29 bear little relationship to each other even though they are reported to be results of tests ostensibly carried out at different strain rates on the same lot of material. It is clear that much more care will have to be exercised in any further examination of the mechanical behavior of lead and its alloys.

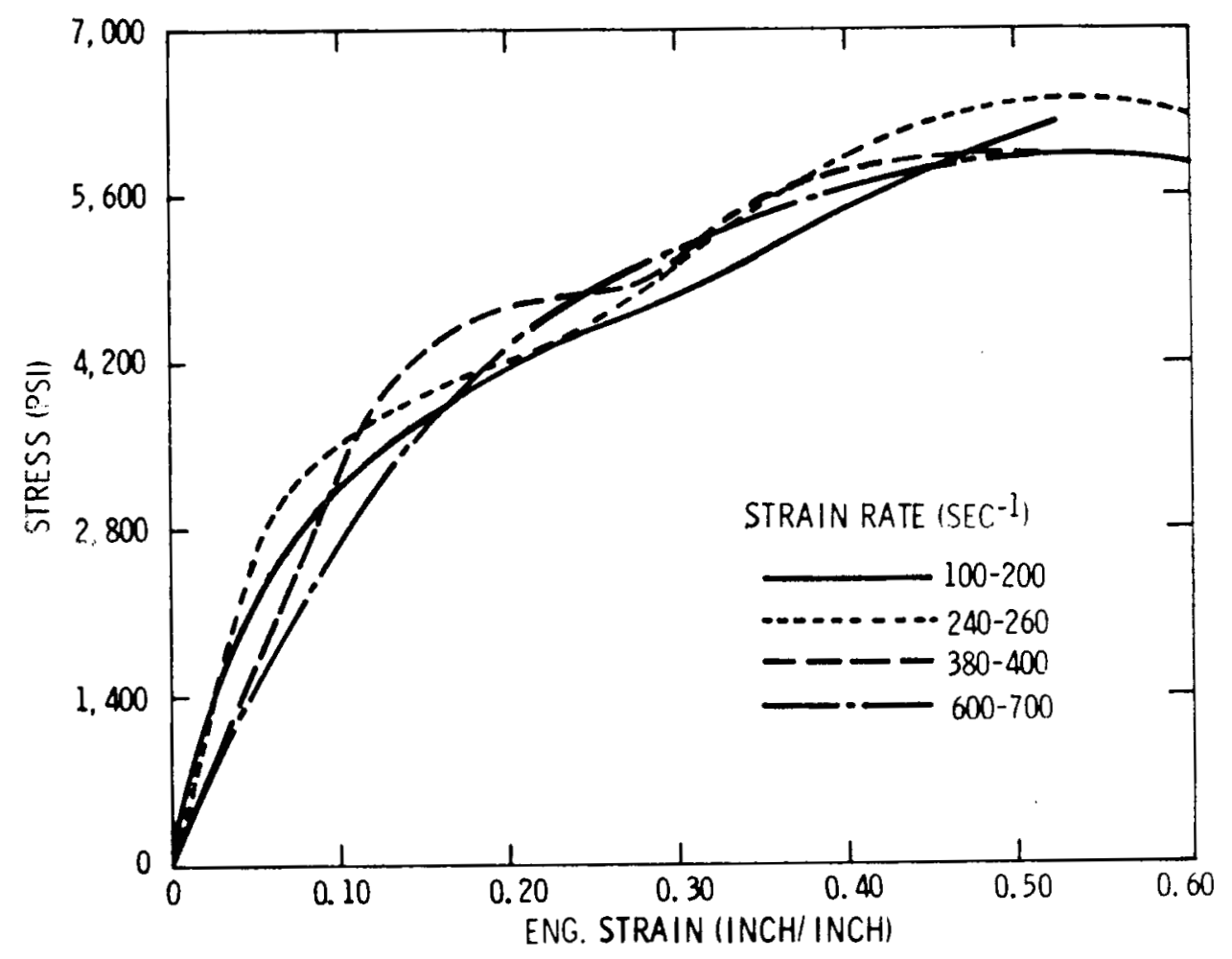

Figure 29. Stress-strain curves of lead for four strain-rate ranges [45].

Summary and Recommendations

This review of the available literature has shown that there are many areas which require further attention before an adequate data base will be established for use with increasingly sophisticated finite-element computer programs. Listed below are the 
authors' recommendations of those subjects which will require further evaluation.

\section{Mechanical properties}

1. Define the temperature, strain-rate, and strain regions for which strain-induced martensite and dynamic strain-aging will control the stress-strain behavior of the austenitic stainless steels used for LWR shipping casks.

2. Establish a data base for selected austenitic stainless steels, "chemical" lead, and as-cast $\alpha$-uranium. The data base should include:

a. The influence of strain-rate and temperature on the tensile, compressive, and shear properties.

b. The influence of chemistry variation on the mechanical properties.

c. The influence of residual stress level and test environ-ment on the mechanical behavior of as-cast $\alpha$-uranium.

3. Develop constitutive equations to describe the stress-strain behavior of LWR shipping cask material under both normal and abnormal (due to strain aging or martensitc formation) modes of deformation.

\section{Thermal Expansion (See Appendix A)}

1. Establish the thermal expansion behavior of $216,317,321$, and 347 stainless steel over the temperature range -40 to $320^{\circ} \mathrm{C}\left(-40\right.$ to $\left.620^{\circ} \mathrm{F}\right)$. 
2. Establish the thermal expansion behavior of typical product forms of $\alpha$-uranium used in shipping cask applications. Particular attention should be given to the expected anisotropic orientation dependence of the thermal expansivity.

Elastic Properties (See Appendix B)

1. Extend moduli measurements for austenitic steels $(304,316$, $321,347)$ to the lowest operating temperatures $\left(-40^{\circ} \mathrm{C}\right)$ associated with shipping casks.

2. Determine elastic properties of $216,308,317$, and 347 stainless steel.

3. Determine elastic properties of selected dilute uranium alloys (e.g., U-2Mo).

The primary emphasis of all of these studies should be a systematic and quantitative assessment including pertinent microstructural information rather than the largely qualitative information available at the present time. 
References

\section{Stainless Steels}

1. Aerospace Structural Metals Handbook, Vol. 2, AFML-TR-68-115, Mechanical Properties Data Center, Belfour stulen, Inc. $(1975)$.

2. G. P. Sanderson and D. T. Llewellyn, "Mechanical Properties of Standard Stainless steels in the Temperature Range $196^{\circ} \mathrm{C}$ to $+800^{\circ} \mathrm{C}, " \mathrm{~J}$. Iron Steel Inst. 207,1129 (1969).

3. H. E. McCoy, Jr., and R. D. Waddell, "Mechanical properties of Several products from a single Heat of Type 304 Stainless Steel," J. Eng. Mat. Tech. 97, 343 (1975).

4. J. P. Hammond and V. K. Sikka, Heat-to-Heat Variations of Total Strain (to 58) at Discrete Stress Levels in Types 316 and 304 stainless steel from $24^{\circ}$ to $316^{\circ} \mathrm{C}$, ORNL/NUREG-TM-57, Oak Ridge National Laboratory, Oak Ridge, TN (November 1976).

5. A. Rosen R. Jago, and T. Kjer, "Tensile Properties of Metastable Stainless Steels," J. Matl. Sci. I, 871 (1972).

6. C. F. Jenkins and G. V. Smith, "Serrated Plastic Flow in Austenitic Stainless Steel," Trans. AIME 245, 2149 (1969).

7. J. T. Barnby, "Effect of Strain Aging on the High Temperature Tensile Properties of an AISI 316 Austenitic Stinless Steel," JISI 203392 (1965).

8. H. Yamada and Li Che-yu, "Stress-Relaxation and Mechanical Equation of State in Austenitic Stainless Steels," Met. Trans. 4, 2133 (1973).

9. R. W. Rohde and J. C. Swearengen, "A Mechanical Equation of State for Inelastic Deformation of Iron: An Analytic Description," J. Eng. Matls. Tech. 99, 59 (1977).

10. R. W. Swindeman, "Representation of the High-Temperature Tensile Behavior of Re-Annealed Type 304 Stainless Steel by the Voce Equation," J. Eng. Matls. Tech. 97H, 98 (1975).

11. J. M. Steichen, "Mathematical Description of the Elevated Temperature Flow Behavior of Type 304 Stainless steel at High Strain Rates," J. Test. Eval. 1, 520 (1973).

12. D. C. Ludwigson, "Modified Stress-strain Relation for FCC Metals and Alloys," Met. Trans. 2, 2825 (1971).

13. E. Voce, "The Relationship Between Stress and Strain for Homogeneous Deformation," J. Inst. Metals 74, 537 (1948). 
14. Nuclear Systems Materials Handbook, Vol. 1, TID 26666, Hanford Engineering Development Laboratory, Richland, WA $(1975)$.

Uranium

15. E. B. Blasch, G. Stukenbroeker, R. J. Lusky, C. Bonilla, and H. Berger, "The Use of Uranium as a Shielding Material," Nucl. Engr.\& Design 13, 146 (1970).

16. D. Calais, G. Saada, and N. Simenel, "Influence of the Anisotropy of the Expansion Coefficient on the Elastic Properties of Uranium, Zirconium, and Zinc," Comptes Rendus 249, 1225 (1959)

17. D. M. R. Taplan and J. W. Martin, "The Effect of Grain Size and Cold Work on the Tensile Properties of Alpha Uranium," J. Less Common Metals 7, 89 (1964).

18. D. M. R. Taplin, "The Tensile properties and Fracture of Uranium Between $-200^{\circ} \mathrm{C}$ and $900^{\circ} \mathrm{C}$," Australian Inst. Met. J. $\underline{12}, 32(1967)$.

19. D. M. R. Taplin and J. W. Martin, "The Metallography and Fracture of Alpha Uranium," Metallurgia 71, 83 (1965).

20. E. G. Zukas, "Properties of As-Cast and Heat Treated 2\% Molybdenum-Uranium," Trans. ASM 51, 752 (1959).

21. F. Jean-Louis and P. Lacombe, "Plastic Deformation of Polycrystalline Uranium Under Tension at Various strain Rates Between 20 and $850^{\circ} \mathrm{C}$," Compt. Rend. Ser. C. 262, 316 (1966).

22. P. D. Tilburg, Impact Testing of Uranium, AWRE 0-33/66, (March 1966).

23. D. M. R. Tapl in and J. W. Martin, "The Effect of Grain Shape on the Tensile properties of -Uranium," J. Nucl. Matls. 10 , $134(1963)$.

24. D. M. R. Taplin and J. W. Martin, "The Effect of Small Additions of Iron and Aluminum on the Tensile Properties of Alpha Uranium," J. Nucl. Matls. 12, 50 (1964).

25. W. L. Owen, "Effect of Hydrogen on Mechanical Properties of Uranium," Metallurgia 66,3 (July 1962).

26. C. Prunier, M. Linard, and F. Giraud-Heraud, "Influence de L'hydrogen Internal sur les Proprietes Mecaniques et Structurales de L'alliage Uranium - 0.28 pds Vanadium," J. Nucl. Matls. $\underline{64}, 14$ (1977). 
27. A. N. Hughes, S. Orman, and G. Picton, "Some Effects of Hydrogen in Uranium," Proc. Intl. Conf. on Hydrogen in Metals, Paris (1972) p. 466.

28. H. R. Gardner and J.W. Riches, "The Effect of Uranium Hydride Distribution and Recrystallization on the Tensile Properties of Uranium," Trans. ASM $\underline{52}, 728$ (1960).

29. G. L. Powell and J. B. Condon, "Hydrogen in Uranium Alloys," in Physical Metallurgy of Uranium Alloys, J. J. Burke, D. A. Colling, A. E. Gorum, and J. Greenspan, eds., Brook Hill Publishing Company, Chestnut Hill, MA (1976) p. 427.

30. D. M. R. Taplin and J.W. Martin, "An Effect of Thermal Cycling Upon the Ductility Transition in Alpha Uranium," J. Inst. Metals 93, 230 (1964).

31. A. N. Hughes, S. Orman, and G. Picton, "Environmental Factors Affecting the Mechanical properties of Uranium, Part I - The Effect of Water Vapour," J. Nucl. Matls. 33, 159 (1969).

32. A. N. Hughes, S. Orman, and G. Picton, "Environmental Factors Affecting the Mechanical Properties of Uranium, Part II - The Mechanism of the water Embrittlement of Uranium," J. Nucl. Matls. 33, 165 (1969).

33. A. N. Hughes, S. Orman, G. Picton, and M. A. Thorne, "The Effect of Humidity on the Low Temperature Tensile Properties of Uranium," J. Nucl. Matls. 33, 99 (1969).

34. P. D. Tilbury, Experiments to Improve the Mechanical Properties of Wrought Uranium, AWRE 038/68, (June 1968).

35. J. Bolton and P. D. Tilbury, "The Influence of Warm Rolling Upon the Ductile/Brittle Transition Temperature of $\alpha$-Uranium," J. Inst. Metals 92, 95 (1963-64).

36. A. Lemogne and P. Lacombe, "Plastic Deformation in Uniaxial Tension of Monocrystals and Polycrystalline Uranium Between $20^{\circ} \mathrm{C}$ and $196^{\circ} \mathrm{C}, " \mathrm{~J}$. Nucl. Matls. 16,129 (1965).

37. C. J. Beevers and G. T. Newman, "The Influence of Heat Treatment on the Tensile Behavior of Uranium in the Temperature Range 200-200 $\mathrm{C}$, J. Less Common Metals 14, 225 (1968).

38. P. A. Loretan and G. Murphy, "The Influence of Rate of Loading and Temperature on the Tensile Properties of Normal Alpha Uranium," Proc. ASTM $\underline{64}, 734$ (1964).

39. J. E. Hockett, P. S. Gilman, and O. D. Sherby, "Compressive Deformation of Polycrystalline Uranium at Low Temperatures," J. Nucl. Matls. 64, 231 (1977). 
Lead

40. G. L. Stukenbroeker, C. F. Bonilla, and R. W Peterson, "The Use of Lead as a Shielding Material," Nucl. Engr. \& Design 13, $3(1970)$.

41. M. Hansen, Constitution of Binary Alloys, 2nd Edition, McGrawHil1, New York (1958).

42. U. S. Lindholm, "Some Experiments with the Split Hopkinson Pressure Bar," J. Mech. Phys. Solids 12, 317 (1964).

43. J.M. Gondusky and J. Duffy, The Dynamic Stress-Strain Relation of Lead and Its Dependence on Grain Structure, Tech. Rpt. No. 53, Brown University, Providence, RI (May 1967).

44. C. H. Mok and J. Duffy, "The Dynamic Stress-Strain Relation of Metals as Determined from Impact Tests with a Hard Ball," Intl. J. Mech. Sci. 7, 355 (1965).

45. J. H. Evans, Structural Analysis of Shipping Casks, Vol. 8, Experimental study of the Stress-strain properties of Lead Under Specified Impact Conditions, ORNL-TM-1312, Oak Ridge National Laboratory, Oak Ridge, TN (August 1970).

46. L. D. Skolov, "A Systemmatic Study of the Dependence of Speed and Temperature of the Resistance to Deformation in One-Phase Metals," Dokl. Akad, Nauk SSSR 70, 839 (1950).

47. H. E. Cline and T. H. Alden, "Rate-Sensitive Deformation in Tin-Lead Alloys," Trans. AIME 239, 710 (1967).

48. J. A. Bailey and A. R. E. Singer, "Effect of Strain Rate and Temperature on the Resistance to Deformation of Aluminum, Two Aluminum Alloys, and Lead," J. Inst. Metals 92, 404 (1963-64).

49. L. D. Skolov, "The Effect of Temperature and Strain Velocity of the Resistance to Deformation of Metals," Russian Met. and Mining 3,93 (1963).

50. N. Lorzon and R. B. Sims, "The Yield Stress of Pure Lead in Compression," J. Mech. Phys. Solids 1,234 (1953).

51. T. E. Tietz, "Mechanical Properties of a High-Purity Lead and a 0.058 Percent Copper-Lead Alloy at Elevated Temperatures," Proc. ASTM 59, 1052 (1959).

52. F. A. Hodierne, "A Torsion Test for use in Metal Working Studies," J. Inst. Metals 91, 267 (1962-63).

53. H. Kolsky, "An Investigation of the Mechanical Properties of Materials at Very High Rates of Loading," Proc. Phys. Soc. $\underline{62 \mathrm{~B}}, 676(1949)$. 
54. E. R. Parker and C. Ferguson, "The Effect of Strain Rate Upon Tensile Impact Strength of Some Metals," Trans. ASM 30 , $68(1942)$.

55. R. F. Steidel and C. F. Makesov, "The Tensile properties of Some Engineering Materials at Moderate Rates of Strain," ASTM Bulletin No. 247, 57 (1960).

56. S. J. Green, C. J. Maiden, S. G. Babcock, and F. L. Schierloh, The High Strain-Rate Behavior of Face Centered Cubic Metals," MSL-69-36, GM Technical Center, (October 1969).

Thermal Expansion

57. Y. S. Touloukian, R. K. Kirby, R. E. Taylor, and P. D. Desai, Thermophysical Properties of Matter, Vol. 12, Plenum Press, New York (1975).

58. D. E. Furman, "Thermal Expansion Characteristics of Stainless Steels Between -300 and $1000^{\circ} \mathrm{F}$," Trans. AIME 188,688 (1950).

59. R. D. Seibel and G. L. Mason, Thermal Properties of High Temperature Materials, WADC-TR-57-468, U.S. Air Force (1958).

\section{Elastic Properties}

60. Source Book on Stainless Steels, American Society for Metals, Metals Park, OH (1976) p. 95.

61. A. J. Goldman and W. D. Robertson, "Elastic Properties of Austenite and Martensite in Iron-Nickel Alloys," Acta Met. 12, 1265 (1964).

62. O. D. Sherby, D. L. Bly, and D. H. Wood, "Plastic Flow and Strength of Uranium and Its Alloys," in Physical Metallurgy of Uranium Alloys, J. J. Burke, D. A. Colling, A. E. Gorum, and J. Greenspan, eds., Brook Hill Publishing Company, Chestnut Hill, MA (1976) p. 311.

63. E. S. Fisher, "Temperature Dependence of the Elastic Moduli in Alpha Uranium Single Crystals, Part IV (298 to $932 \mathrm{~K})$," J. Nucl. Matls. 18,39 (1966).

64. P. E. Armstrong, D. T. Eash, and J. E. Hockett, "Elastic Moduli of Alpha, Beta, and Gamma Polycrystalline Uranium," J. Nucl. Matls. 45, 211 (1972-73).

65. W. Koster, "Die Temperaturabhagegkeit des Elastizitats-moduls reiner Metalle," Zeit. fur Metkde 39, 1 (1948). 


\section{APPENDIX A}

\section{Thermal Expansion Behavior of Selected}

Stainless Steels, Uranium, and Lead

The thermal expansion behavior of stainless steel, uranium, and lead are presented below. The linear thermal expansion has been presented as $\Delta \mathrm{L} / \mathrm{L}_{0}$ where (see Appendix $\mathrm{C}$ for definition of symbols):

$$
\Delta L=L_{T}-L_{O}
$$

\section{Stainless Steels}

The thermal expansion behavior of the stainless steels presently being considered is tabulated in Table A-I and summarized in Figure $A-1$. The data are quite limited; none were found for 216 or 317 stainless steels. In addition, that for 321 stainless is well above the temperature range of primary interest for shipping applications. However, Figure A-l does suggest that the thermal expansivity of many stainless steels is quite similar and that, to a first approximation, they may be represented by that of 304 stainless steel, i.e. [57],

$$
\begin{aligned}
\Delta \mathrm{L} / \mathrm{L}_{\mathrm{O}}(8)=0.358 & +9.471 \times 10^{-4} \mathrm{~T}+1.031 \times 10^{-6} \mathrm{~T}^{2} \\
& -2.978 \times 10^{-10} \mathrm{~T}^{3}\left(\mathrm{~T} \text { in }{ }^{\circ} \mathrm{K}\right)
\end{aligned}
$$

The formation of martensite at low temperature or $\delta$-ferrite in weldments can be expected to alter this behavior in an as yet undetermined manner. 


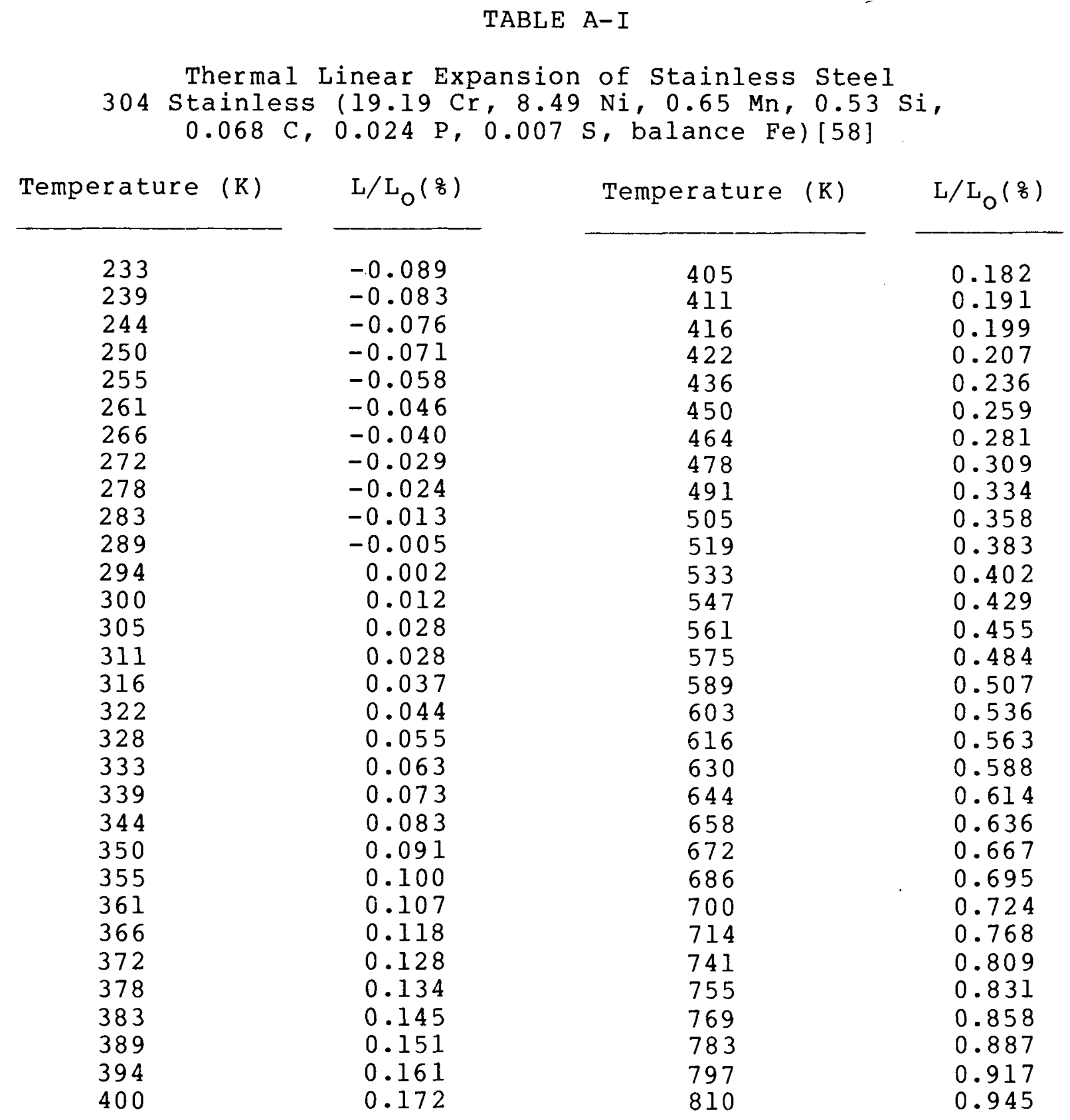




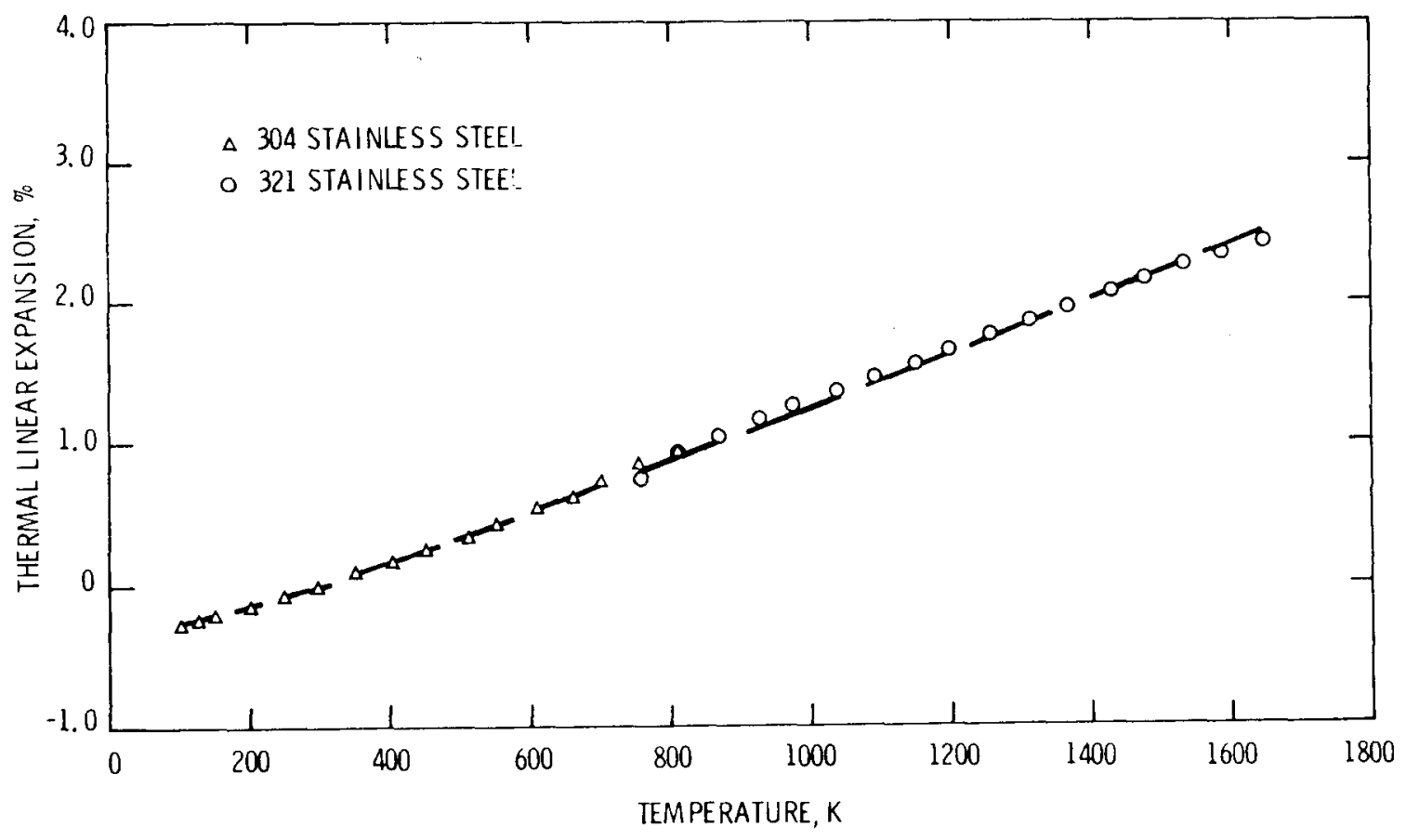

Figure A-1. Thermal expansion of 304 and 321 stainless steel.

$\underline{\text { Uranium }}$

The thermal expansion behavior of $\alpha$-uranium is quite complex (see Table A-II and Figure A-2). Single crystal measurements indicate that the expansion behavior, in contrast to stainless steel or lead, is highly anisotropic and depends upon the particular crystal-lographic orientation being considered. This suggests that the thermal expansion coefficients of polycrystalline uranium will be extremely sensitive to prior processing history and are expected to be quite variable. To date there have been no investigations of the influence of thermomechanical treatment on the thermal expansivity of $\alpha$-uranium so that any formalism proposed to describe its behavior must be considered as only a first approximation. 
TABLE A-II

Thermal Linear Expansion of Polystalline $\alpha$-Uranium

\begin{tabular}{|c|c|c|c|}
\hline$\frac{\text { Curve } 13 / 99.8}{\text { Temperature }}$ & $\frac{\mathrm{U}, 0.14 \mathrm{C}, 0.03 \mathrm{Si})}{(\mathrm{K})} \frac{0.03 \mathrm{~L} / \mathrm{L}_{0}(8)}{\Delta(8)}$ & $\begin{array}{l}\text { Curve } 32 \text { ("Pure" } \\
\text { Temperature (K) }\end{array}$ & $\frac{\text { Uranium })}{\Delta L / L_{0}(q)}$ \\
\hline 291 & -0.0032 & 293 & 0.000 \\
\hline 373 & 0.127 & 373 & 0.118 \\
\hline 473 & 0.306 & 473 & 0.268 \\
\hline 573 & 0.506 & 575 & 0.424 \\
\hline 673 & 0.728 & 673 & 0.594 \\
\hline
\end{tabular}

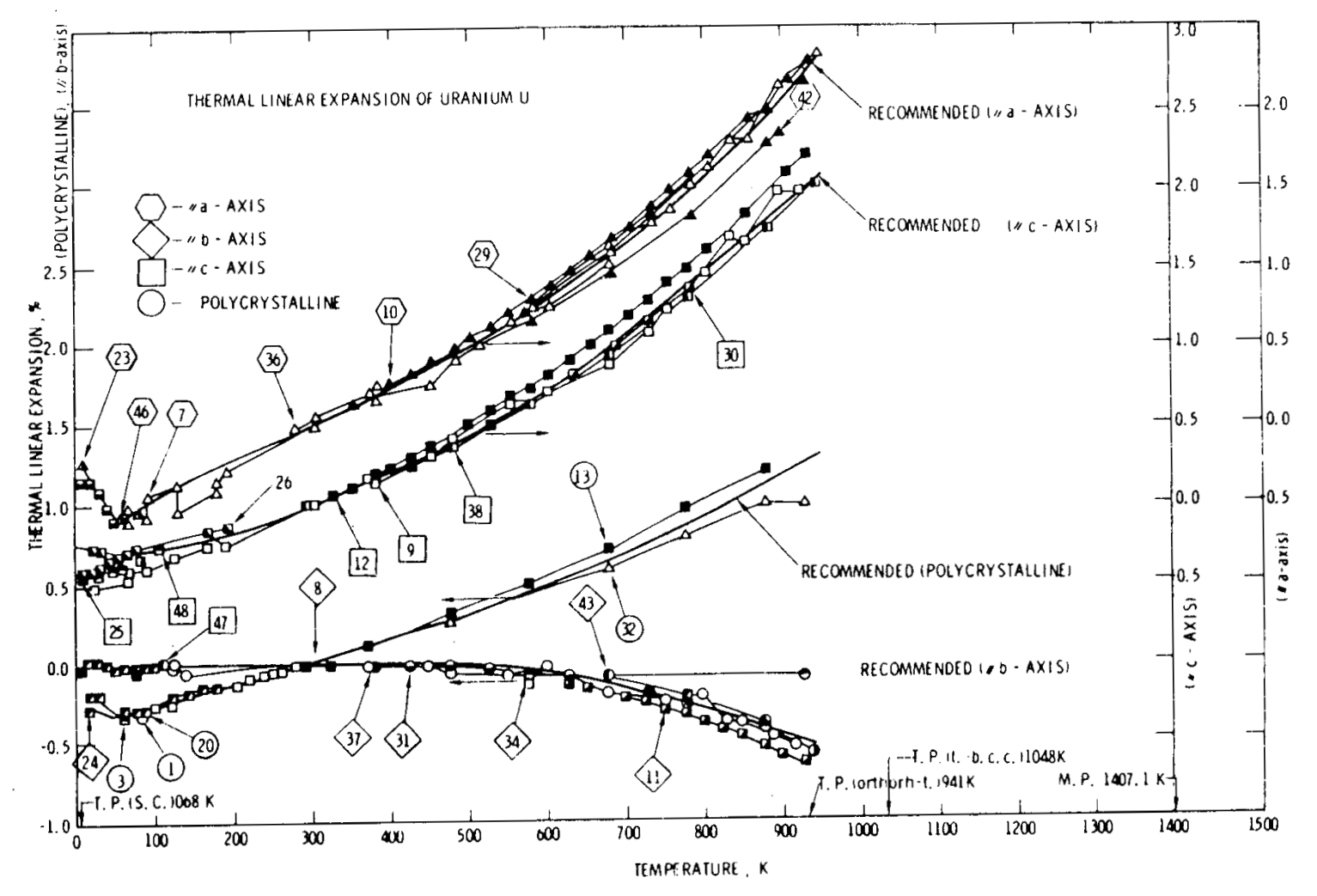

Figure A-2. Thermal expansion behavior of $\alpha$-uranium, curve reference numbers given by Toulonkian et al. [57]. 
Notwithstanding, Touloukian et al. [57] recommend that the thermal expansion behavior of polycrystalline $\alpha$-uranium can be represented by:

$$
\begin{aligned}
& \Delta \mathrm{L} / \mathrm{L}_{\mathrm{O}}(8)=-0.379+ 1.264 \times 10^{-3} \mathrm{~T}-8.982 \times 10^{-8} \mathrm{~T}^{2} \\
&+ 6.844 \times 10^{-10} \mathrm{~T}^{3}(293 \mathrm{~K}<\mathrm{T}<941 \mathrm{~K}) . \\
&\left(\mathrm{T} \text { in }{ }^{\circ} \mathrm{K}\right)
\end{aligned}
$$

As noted above, the error limits to be associated with this relationship must be established.

Lead

The thermal expansion behavior of lead is summarized in Figure A-3. Although the bulk of this data refers to high purity lead it appears that, in those instances where the impurity levels approach that of "chemical" lead, the expansion behavior remains relatively unaffected. Indeed, it has been proposed that all of the tabulated values can be represented to within \pm 3 percent over the temperature range 100 to 600 $K$ by the following equation [57]:

$$
\begin{gathered}
\Delta \mathrm{L} / \mathrm{L}_{\mathrm{O}}(8)=0.786+2572 \times 10^{-3} \mathrm{~T}+1.147 \times 10^{-7} \mathrm{~T}^{2} \\
+8.770 \times 10^{-10} \mathrm{~T}^{3}\left(\mathrm{~T} \text { in }{ }^{\circ} \mathrm{K}\right)
\end{gathered}
$$




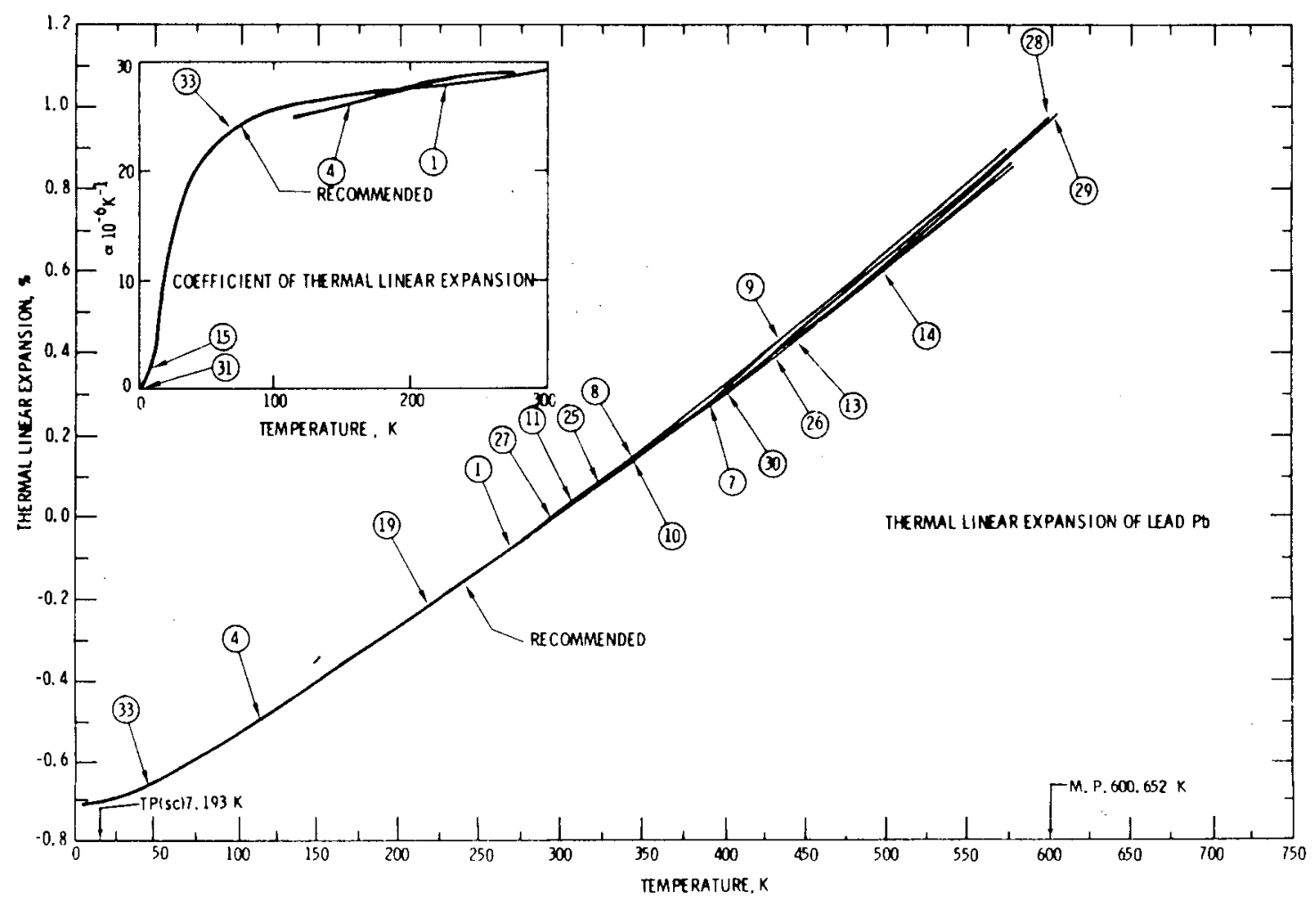

Figure A-3. Thermal expansion behavior of lead, curve reference numbers given by Touloukian et al. [57].

with the recommended values being

\begin{tabular}{|c|c|c|}
\hline Temperature $(\mathrm{K})$ & $\Delta \mathrm{L} / \mathrm{L}_{0}(\mathrm{q})$ & $\underline{\alpha \times 10^{6}\left(\mathrm{~K}^{-1}\right)}$ \\
\hline 100 & -0.526 & 25.6 \\
\hline 200 & -0.261 & 27.5 \\
\hline 293 & 0.000 & 28.9 \\
\hline 400 & 0.317 & 30.6 \\
\hline 500 & 0.638 & 33.3 \\
\hline 600 & 0.988 & 36.7 \\
\hline
\end{tabular}

where

$$
\alpha=\left(1 / \mathrm{L}_{293}\right) \mathrm{dL} / \mathrm{dT}
$$




\section{APPENDIX B \\ Elastic Properties of Selected Stainless Steels, Uranium, and Lead}

\section{Stainless Steels}

Typical values for the elastic constants of selected stainless steels are given in Tables B-I through B-VII and Figures B-1 through B-6. Examination of this data indicates that variations in chemistry within the group of austenitic stainless steels presently under consideration have little effect on their elastic properties. Furthermore, increasing temperature generally results in a gradual decrease in the Young's and shear moduli and an accompanying increase in Poisson's ratio. Again, martensite formation can be expected to cause changes. For example, the presence of martensite has been shown to lower the modulus of the parent austenite phase [61]. 
TABLE B-I

Effect of Temperature on the Elastic Constants of Selected Stainless steels [60]

\begin{tabular}{|c|c|c|c|c|}
\hline \multirow[b]{2}{*}{ Type } & \multirow[b]{2}{*}{297} & \multicolumn{3}{|c|}{ Temperature (K) } \\
\hline & & $422^{+}$ & 533 & 644 \\
\hline \multicolumn{5}{|c|}{ Young's Modulus $\left(10^{3} \mathrm{ksi}\right)$} \\
\hline 304 & 29.0 & 27.3 & 26.0 & 24.8 \\
\hline 316 & 28.4 & 27.2 & 26.4 & 25.6 \\
\hline 317 & 27.0 & 26.4 & 25.0 & - \\
\hline 321 & 28.9 & 27.3 & 25.8 & 24.5 \\
\hline \multirow[t]{2}{*}{347} & 28.9 & 27.5 & 26.1 & 24.8 \\
\hline & Shear & Modulus & $\left(10^{3} \mathrm{ksi}\right)$ & \\
\hline 304 & 11.2 & 10.4 & 9.8 & 9.3 \\
\hline 316 & 11.3 & 10.8 & 10.2 & 9.2 \\
\hline 317 & - & - & - & - \\
\hline 321 & 11.2 & 10.6 & 9.9 & 9.4 \\
\hline 347 & 11.4 & 10.7 & 10.1 & 9.5 \\
\hline \multicolumn{5}{|c|}{ Poisson's Ratio } \\
\hline 304 & 0.30 & 0.31 & 0.31 & 0.32 \\
\hline 316 & 0.26 & 0.26 & 0.30 & 0.34 \\
\hline 317 & 0.25 & 0.28 & 0.31 & 0.31 \\
\hline 321 & 0.28 & 0.29 & 0.30 & 0.31 \\
\hline 347 & 0.28 & 0.29 & 0.30 & 0.31 \\
\hline
\end{tabular}


TABLE B-II

\section{Young's Modulus for Annealed 304 Stainless Steel [14]}

\section{ASME CODE}

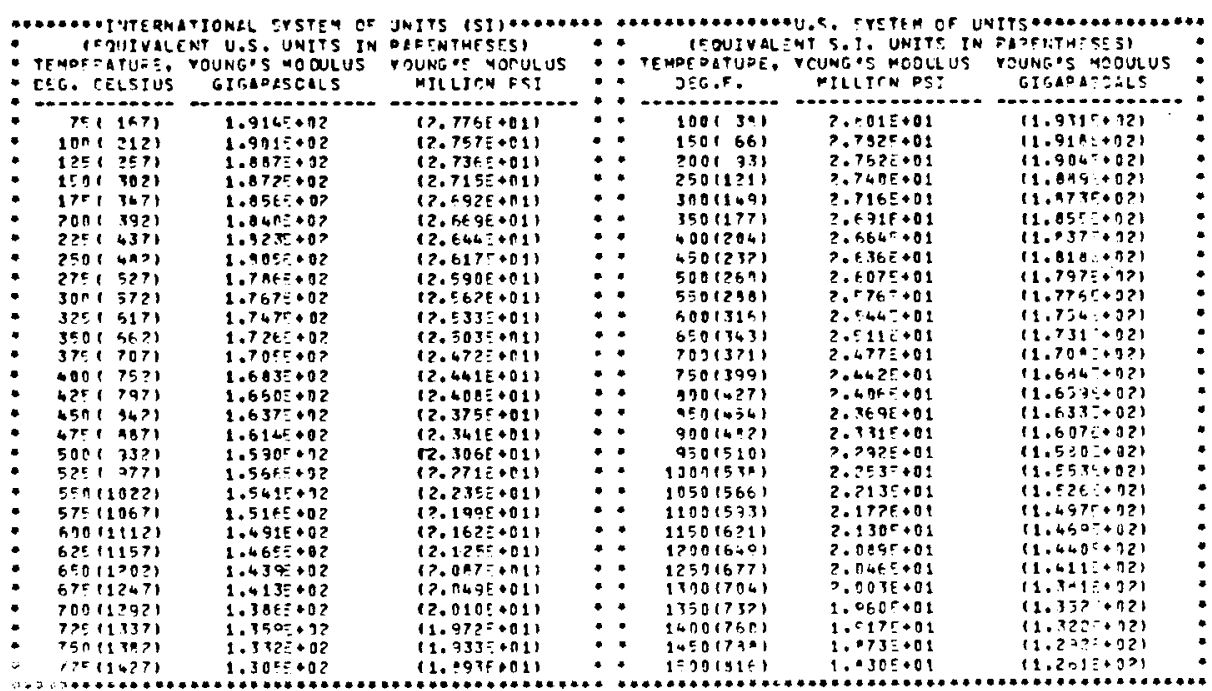

TABLE B-III

Shear Modulus for Annealed 304 Stainless Steel [14]

1971 ASME CODE

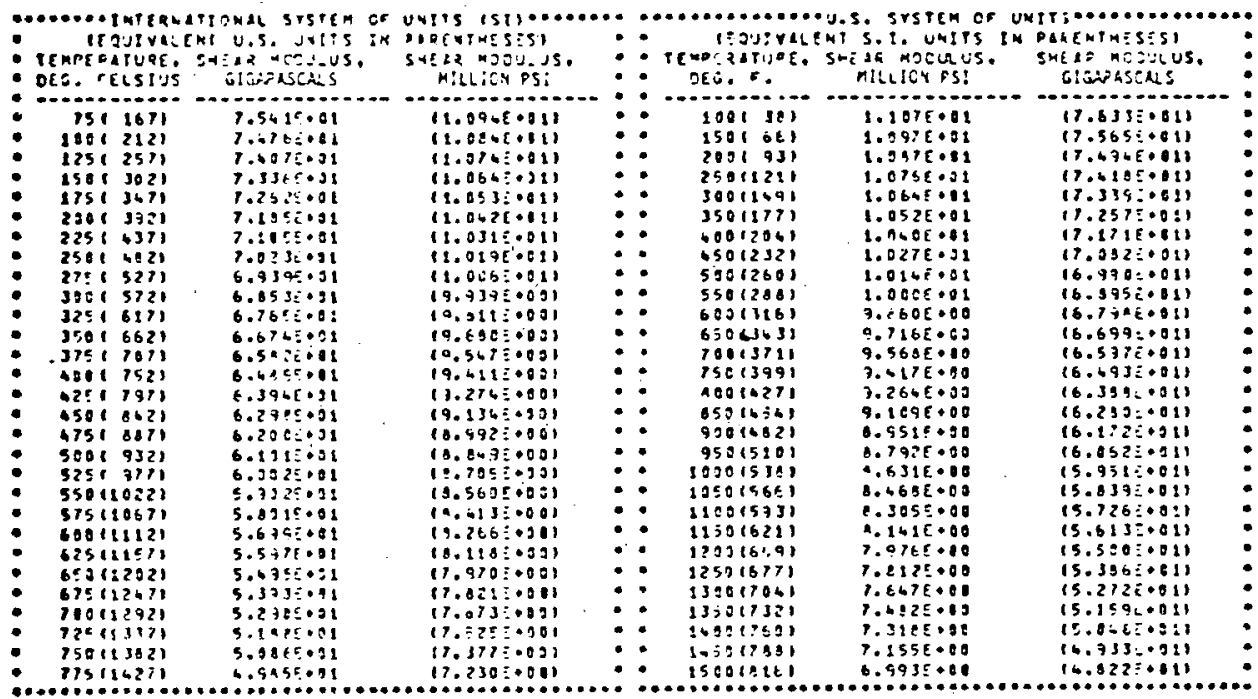


TABLE B-IV

Poisson's Ratio for

Annealed 304 Stainless Steel [14]

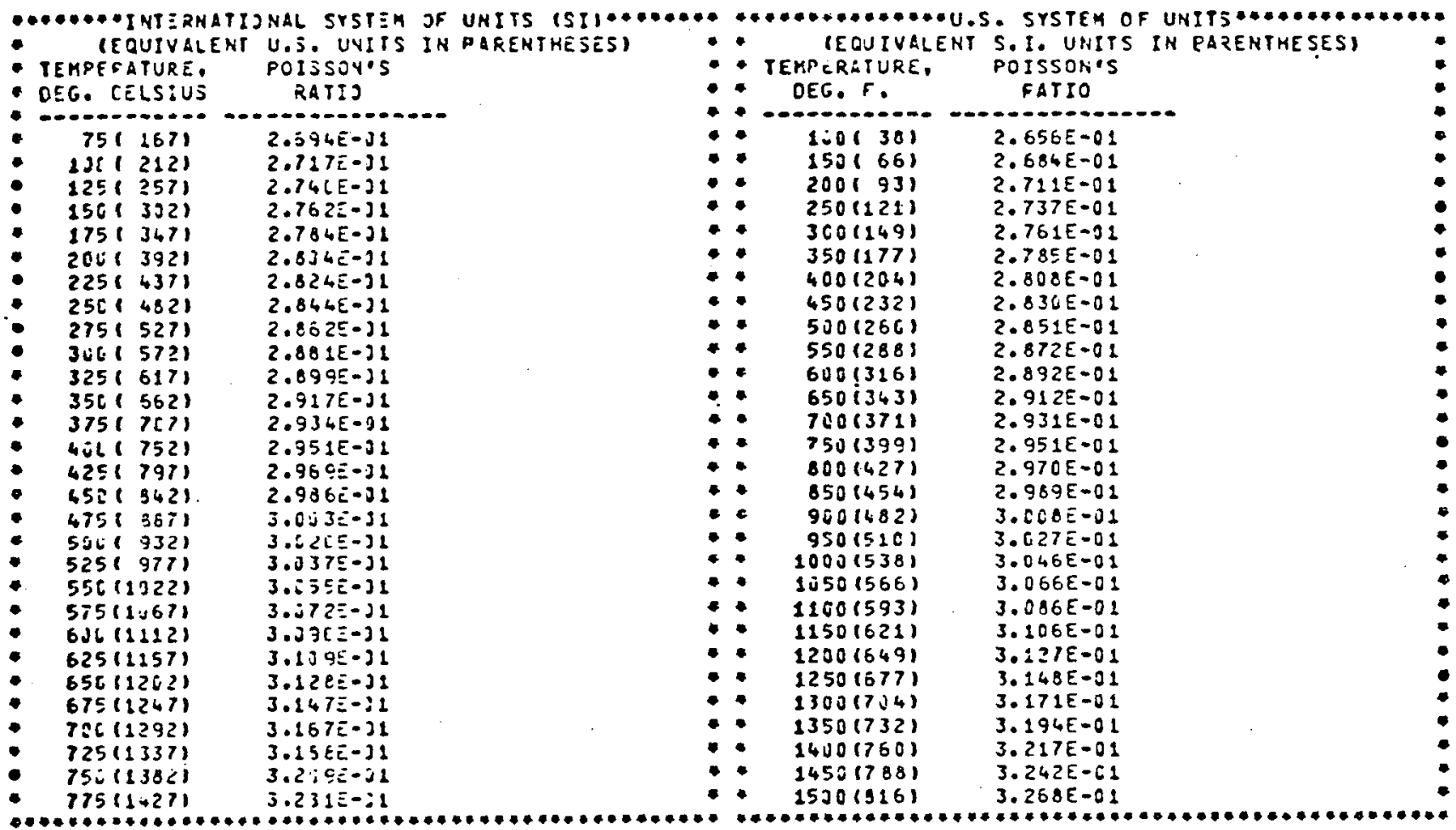

TABLE B-V

Young's Modulus for

Annealed 316 Stainless Steel [14]

1971 ASME CODE

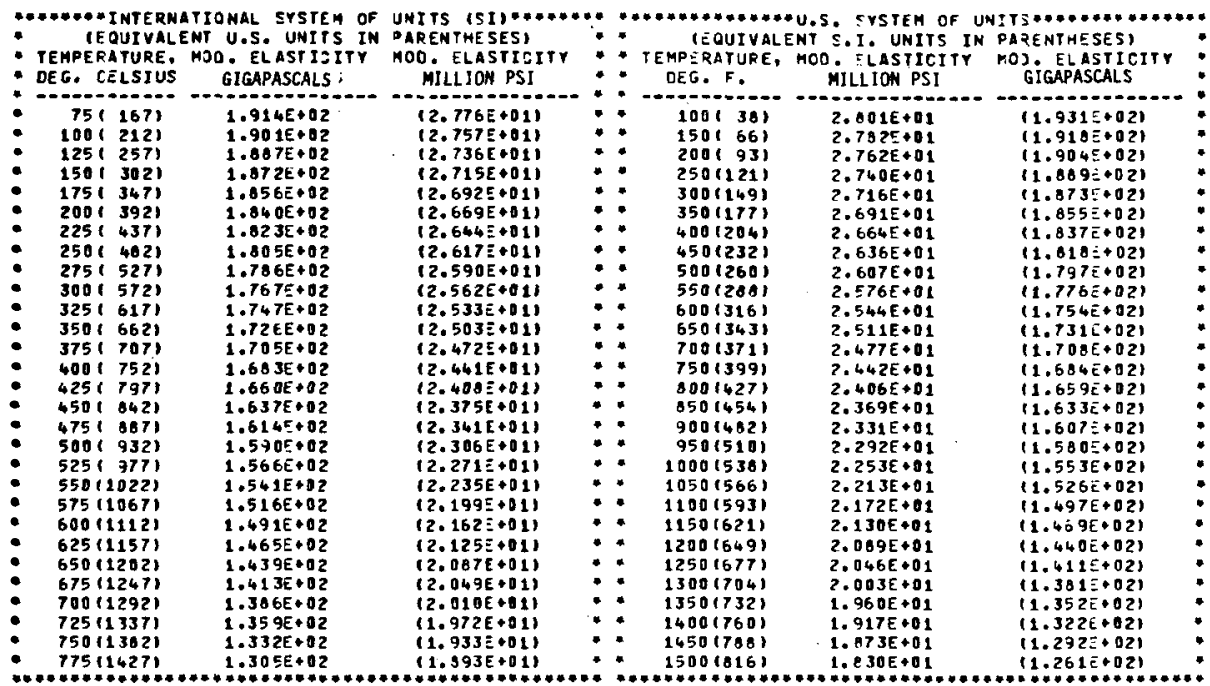


TABLE B-VI

\author{
Shear Modulus for \\ Annealed 316 Stainless Steel [14]
}

1971 ASME CODE

\begin{tabular}{|c|c|c|c|c|c|}
\hline 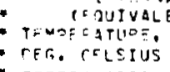 & 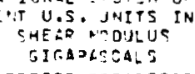 & $\begin{array}{l}\text { PAFENTHESTS } \\
\text { SHEAC MJOULUS } \\
\text { MILICICN FSI }\end{array}$ & $\begin{array}{l}* \text { IEQUIVAL } \\
: \text { TEMDEQATUPE, } \\
\text { OEGOF. }\end{array}$ & $\begin{array}{l}\text { NT S.T. UNITS IN } \\
\text { SHEAE MOOULUS } \\
\text { MILLION PSI }\end{array}$ & $\begin{array}{l}\text { PAPENTHESESI } \\
\text { SHEAR YOOULUS } \\
\text { GTTAPASCALS }\end{array}$ \\
\hline & & & & & \\
\hline $\begin{array}{r}75\{167\} \\
100(212\}\end{array}$ & $\begin{array}{l}7.5+1=01 \\
7.47 E+01\end{array}$ & $\begin{array}{l}\{1.0942 .011 \\
\left(1.04_{4}=01\right)\end{array}$ & $\begin{array}{l}1001381 \\
1501651\end{array}$ & $2.107 E+01$ & $(7.633=+01)$ \\
\hline$t 2=1 \quad 3=71$ & $7.407 t+01$ & & 2001331 & $\begin{array}{l}1.097 E+01 \\
1.087 E+01\end{array}$ & $\begin{array}{l}(7.565 E+01) \\
(7.494 E+01)\end{array}$ \\
\hline $15 n 13021$ & $7.316=+11$ & $(1.064 E+01)$ & $25011 ? 11$ & $1, \cap 76 E+01$ & $17.4185+011$ \\
\hline $17 \div 23471$ & $7.7592+11$ & $(1 \cdot n \leq 3 z+01)$ & $300(1+9)$ & $1.064 E+01$ & $(9.3 .39 c+01)$ \\
\hline 20013031 & $7.1955+112$ & 11.3425 .011 & 35011771 & $1.052 E+01$ & $(7.257 E+B 1)$ \\
\hline 72514371 & $7 \cdot 1.15 \div+71$ & $(1.031=+01)$ & $400(? 34)$ & $1.040 E+01$ & $(7.1715+01)$ \\
\hline 2501 tै? & $7+0>3:+\pi 1$ & $(1.0195+21)$ & $450(232)$ & $1.0278+01$ & $(7.0825+01)$ \\
\hline 3750157 & $6 .+30=+71$ & $(1.0005+01)$ & $597(25 n)$ & $1.01+E+01$ & $(6.990 E+01)$ \\
\hline $3001=721$ & $5.9535+11$ & $(\theta, 9.30 E+n 0)$ & 55012801 & $1.000 E+01$ & $(6.895 \mathrm{E} .01)$ \\
\hline 325171 & $6.755+01$ & $1 C .311 \equiv+601$ & $500(315)$ & $3.860 \varepsilon+09$ & $18.79 A E+011$ \\
\hline $35 n=1$ śn?l & $6.674:+11$ & $(9.680 \mathrm{~F}+03)$ & $650(343)$ & $9.716 E+00$ & $(6.690 F+01)$ \\
\hline $375: 7071$ & $6.5+25+01$ & $19.547 E+0 \cap 1$ & $7001371)$ & $3.5 B A E+O O$ & $16.5975+011$ \\
\hline $4091 \quad x>1$ & $6.43 c=+111$ & $(9.411 E+00)$ & 75013991 & $9,417 E+00$ & $16.493 E+011$ \\
\hline $4==1737$ & $6 \cdot 534=111$ & $19+2742 \div+10)$ & $900(427)$ & $9 . \geq 645 \cdot 00$ & $(6.35 \mathrm{BE}+91)$ \\
\hline $4=0,194 \geqslant 3$ & $6.29 .5=411$ & $10,134[091$ & $A 50(656)$ & $3.109 E+00$ & $(6.2805+81)$ \\
\hline $\begin{array}{lll}4754 & +293\end{array}$ & $t \cdot ?) r=1 t$ & $\{0.9925+00\}$ & $300(492)$ & $3.45,15+03$ & $16.1725+01\}$ \\
\hline 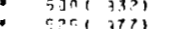 & $\{-191=01$ & $\because \because+940=0$ (1) & 35015101 & 8.7926 & $16.062 E+011$ \\
\hline 02.13771 & $6.0 n ? \div .11$ & $(a .7055+00)$ & 103015381 & R.EYIE & $15.9515+011$ \\
\hline $550(102 ? 1$ & $5 \cdot 7325+11$ & $(5 \cdot 560 \equiv \cdot 09)$ & $1050(556)$ & $9.65 B E \bullet 00$ & $(5.279=+011$ \\
\hline e $75(19+7)$ & $5 \cdot 911=71$ & $(9.413=0.71)$ & $1100(533)$ & $9.30 \leq 0+00$ & $(5.725 E+01)$ \\
\hline $\tan 111121$ & $5.630-+71$ & (A, ZE:bE+JU) & $1150(621)$ & $2.141 E+00$ & $(5.61\} c+n 1)$ \\
\hline $5>5+11571$ & $5.597: \cdot 01$ & $(x+119=00)$ & 120010401 & $7.075 E \cdot 09$ & $(5.500 E+01)$ \\
\hline & $5.4 \cdot 2 r=+31$ & $17.970 E \cdot 001$ & $1>5, n(577)$ & $7, A 125+09$ & $(5.3 \times 6 z+01)$ \\
\hline $475(1769)$ & $5.3+2+01$ & $(7,4215+0$ ) & $1300(704)$ & 7.5475 & $(5.272=+01)$ \\
\hline 700113031 & $5 \cdot ?+n=01$ & 17.67 & 135017321 & $7.4 \mathrm{E2E}+00$ & $15.150 \leq+011$ \\
\hline $\begin{array}{l}750113371 \\
7=0\end{array}$ & $5.1898+71$ & $25=0031$ & $14001750)$ & $7 \cdot 318 E+00$ & $15.0465+011$ \\
\hline $7=0113 p ?$ & $5094=+71$ & $(7.377=001)$ & 145017921 & $7.155 E+0 \pi$ & $(4.9335+01)$ \\
\hline $77=(1+? ?\}$ & $4.935 \div+11$ & $(7.23 ? 5+00)$ & $t=00(716)$ & $.973=010$ & $(4.222 E+01)$ \\
\hline
\end{tabular}

TABLE B-VII

Poisson's Ratio for

Annealed 316 Stainless Steel [14]

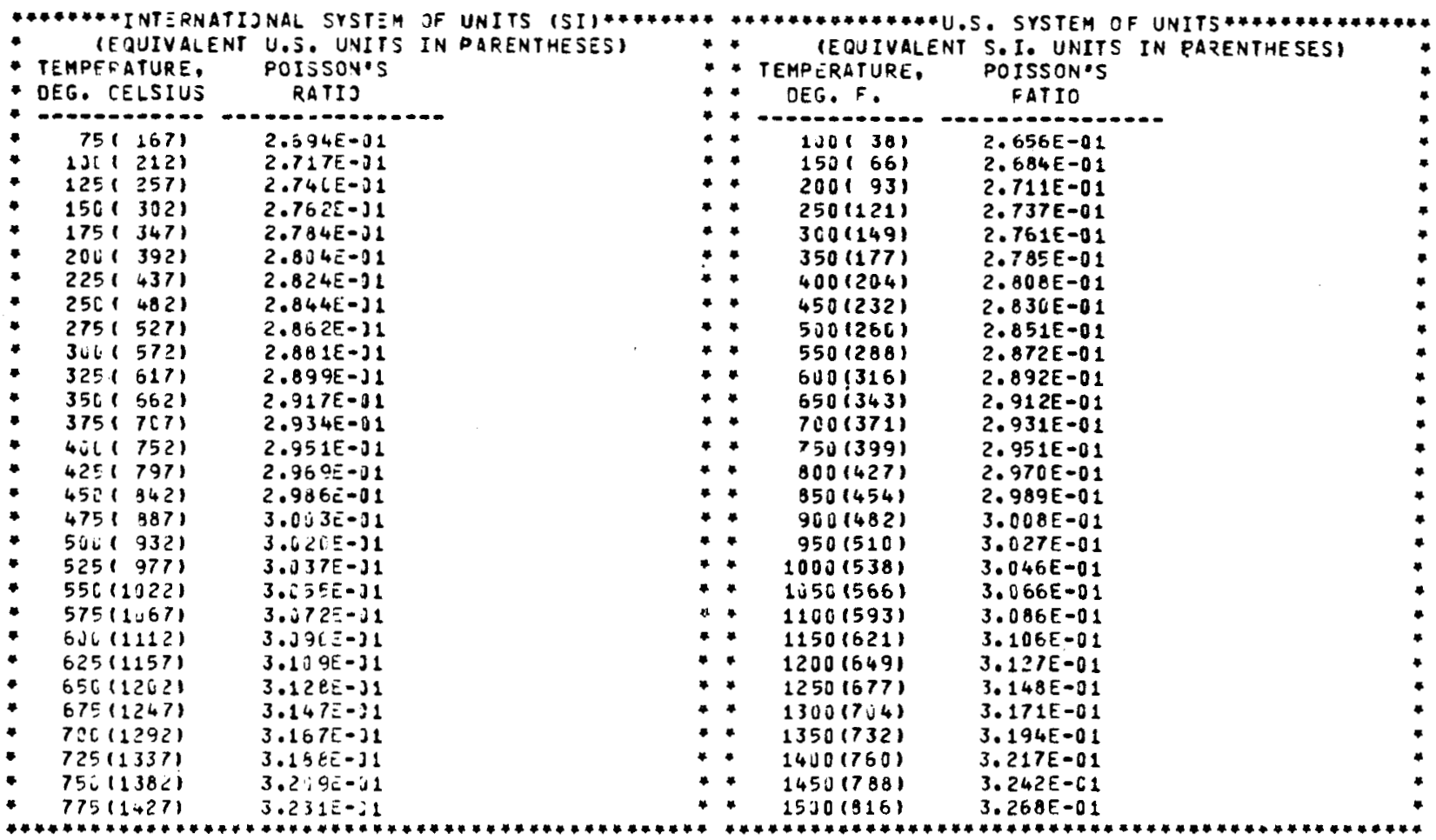




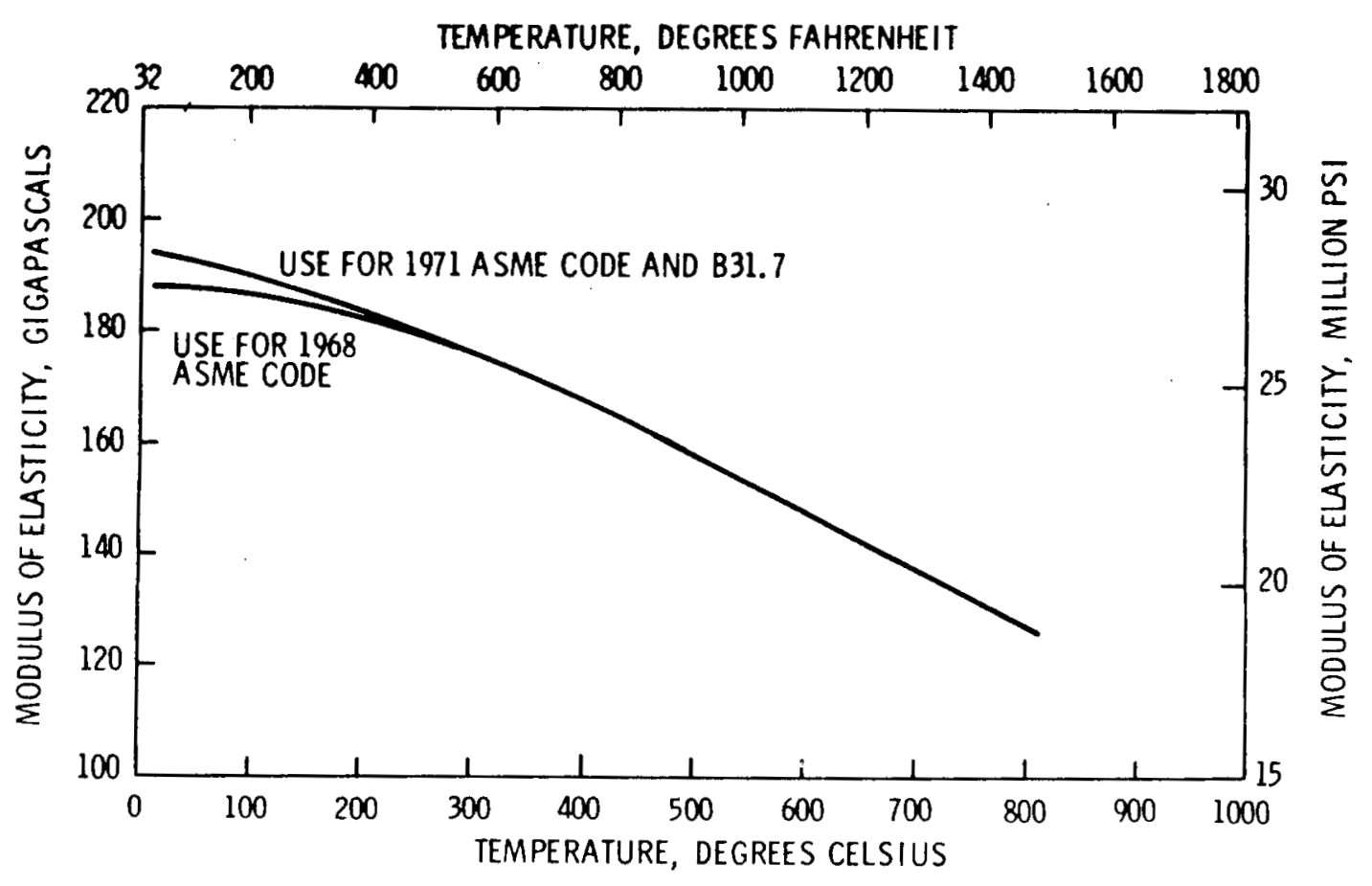

Figure B-1. Young's modulus of 304SS, annealed [14].

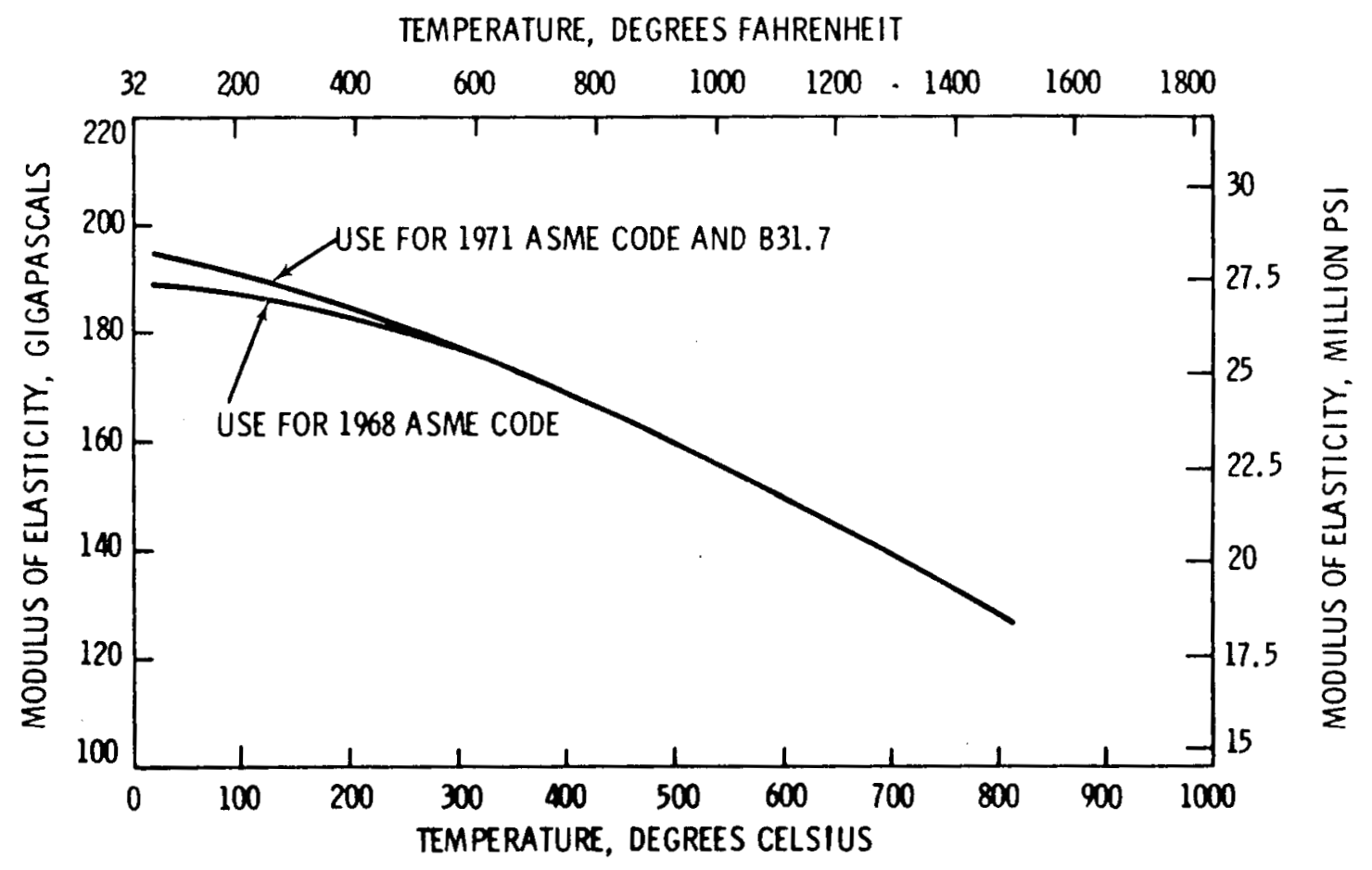

Figure B-2. Young's modulus of 316SS, annealed [14] . 


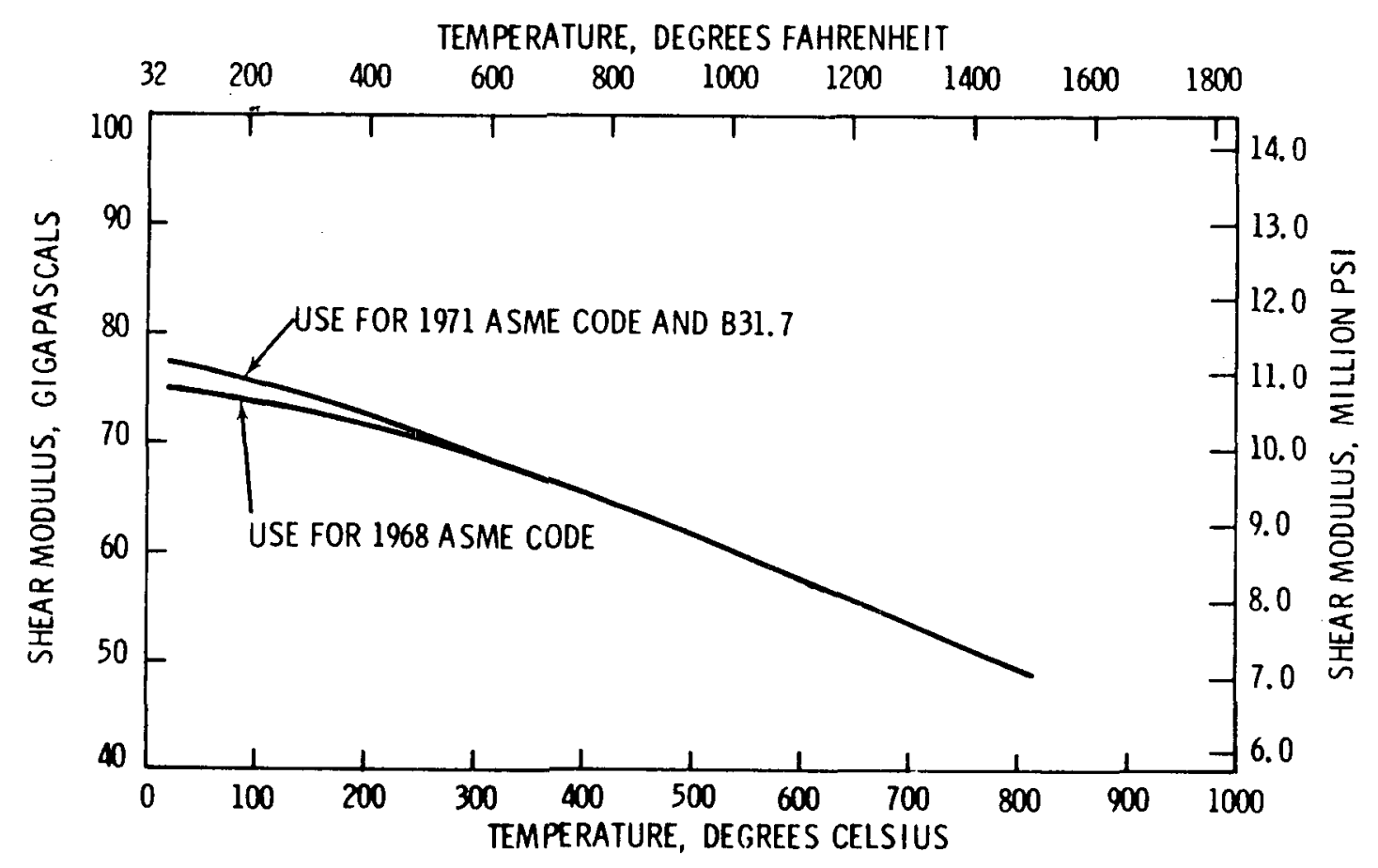

Figure B-3. Shear modulus of $304 \mathrm{SS}$, annealed [14].

TEMPERATURE, DEGREES FAHRENHEIT

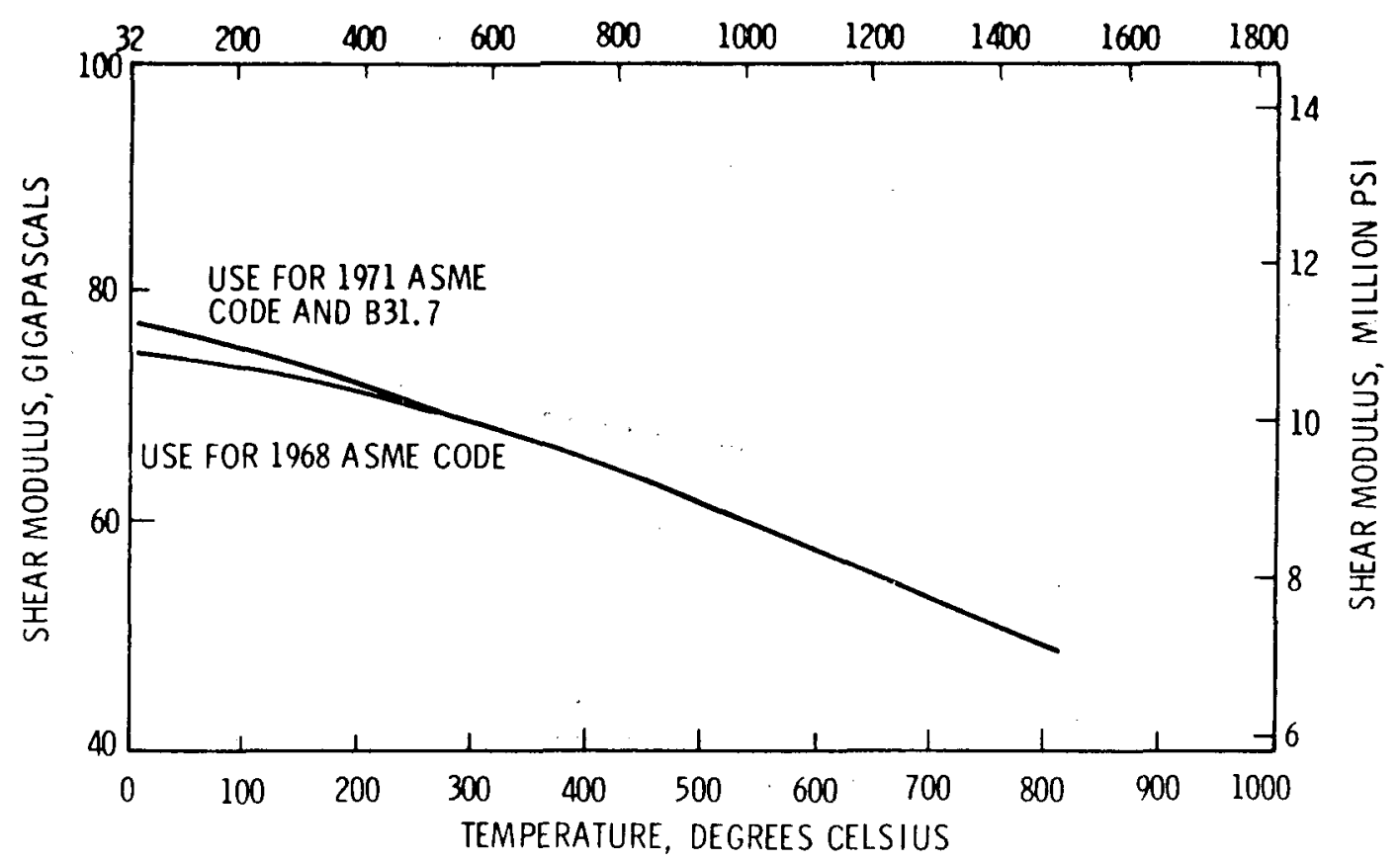

Figure B-4. Shear modulus of 316SS, annealed [14]. 


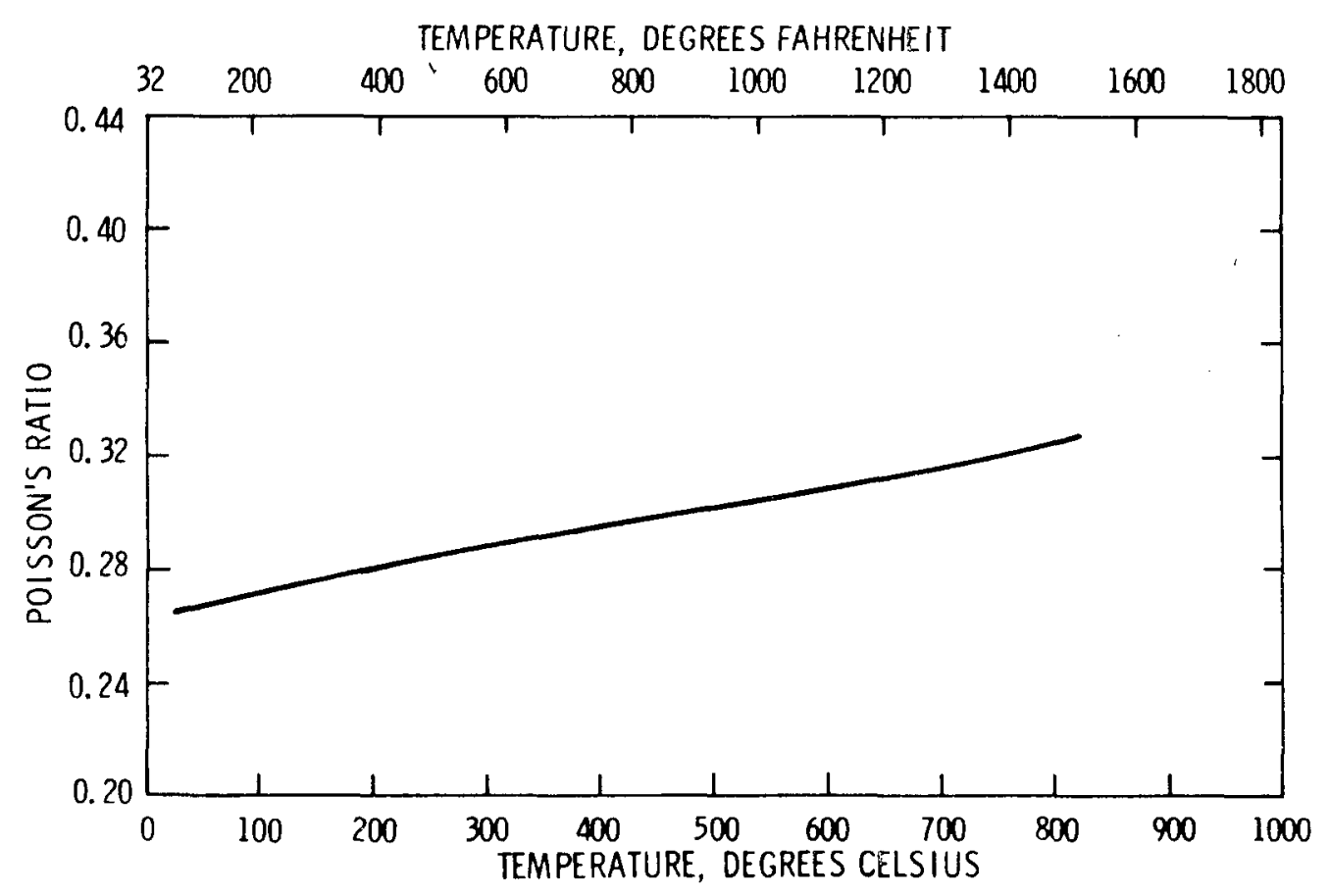

Figure B-5. Poisson's ratio of 304SS, annealed [14].

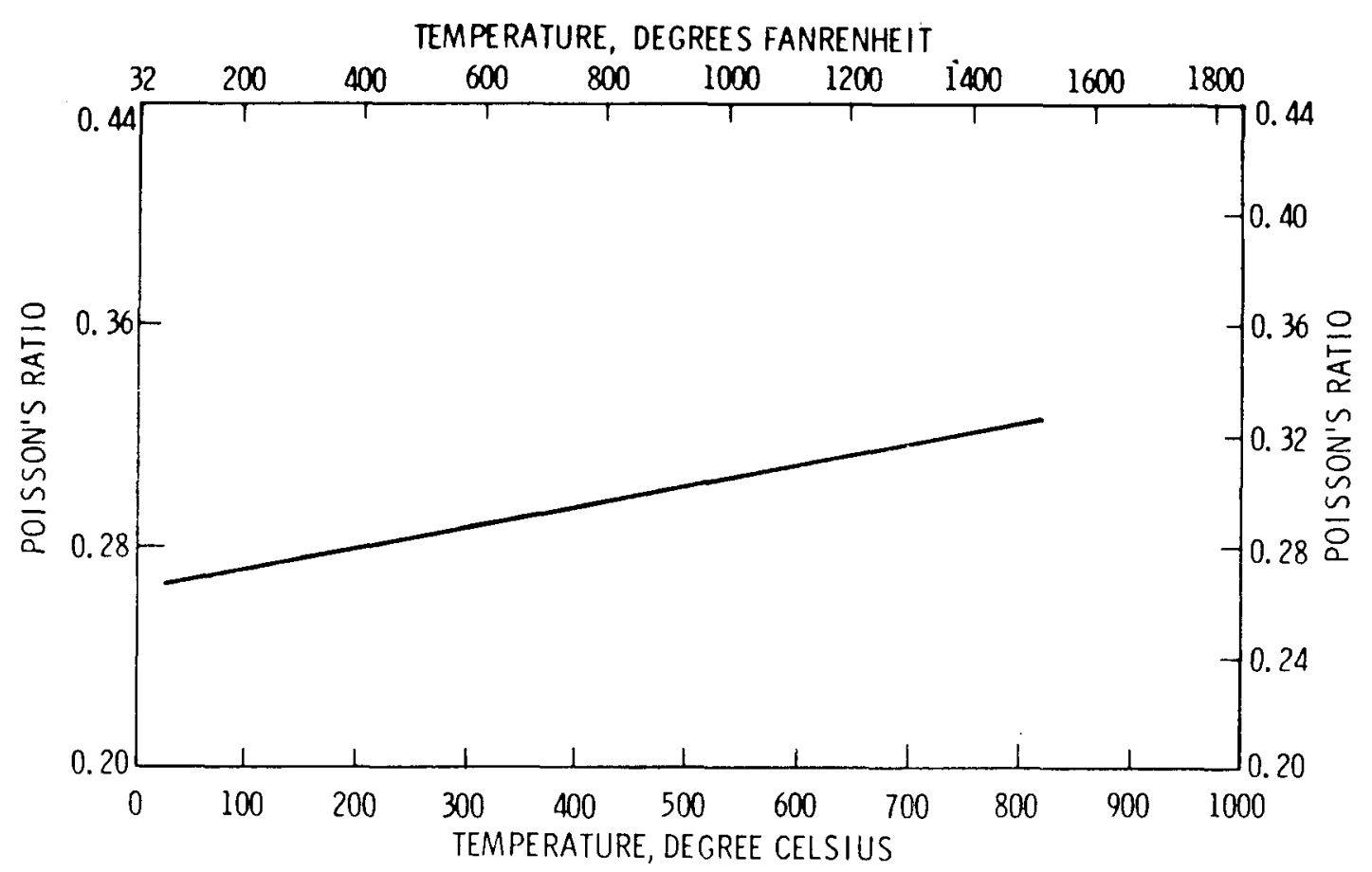

Figure B-6. Poisson's ratio of 316SS, annealed [14]. 
Uranium

The influence of temperature on the elastic properties of uranium are presented in Table B-VIII and Figure B-7. The solid curve in the latter refers to the modulus of random, non-textured polycrystalline uranium [62], while the minimum and maximum

TABLE B-VIII

Probable Values for Elastic Moduli

of Non-textured Polycrystalline uranium [64]

\begin{tabular}{|c|c|c|c|}
\hline $\begin{array}{c}\text { Temperature } \\
(\mathrm{K})\end{array}$ & $\begin{array}{l}\text { Young's } \\
\text { Modulus } \\
\text { (10 } 10^{2} \text { psi) } \\
\end{array}$ & $\begin{array}{l}\text { Shear } \\
\text { Modulus } \\
\text { (10 psi) }\end{array}$ & $\begin{array}{c}\text { Poisson's } \\
\text { Ratio } \\
\end{array}$ \\
\hline $\begin{array}{lll}2 & 0 & 0 \\
3 & 0 & 0 \\
4 & 0 & 0 \\
5 & 0 & 0 \\
6 & 0 & 0 \\
7 & 0 & 0 \\
8 & 0 & 0\end{array}$ & $\begin{array}{l}30.5 \\
29.1 \\
27.6 \\
26.1 \\
24.3 \\
22.3 \\
19.7\end{array}$ & $\begin{array}{r}12.50 \\
11.80 \\
11.20 \\
10.50 \\
9.70 \\
8.70 \\
7.60\end{array}$ & $\begin{array}{l}0.22 \\
0.23 \\
0.23 \\
0.23 \\
0.25 \\
0.28 \\
0.30\end{array}$ \\
\hline
\end{tabular}

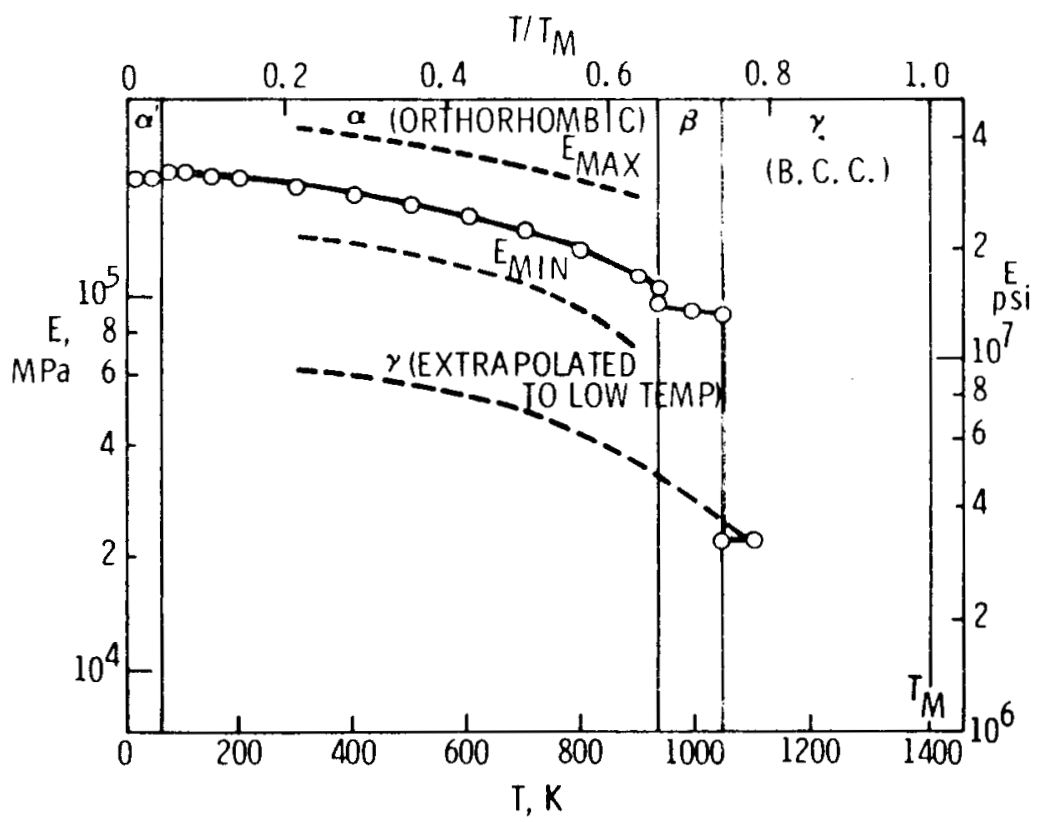

Figure B-7. Young's modulus of pure polycrystalline uranium as a function of temperature. The modulus of nontextured uranium is given by the solid line. The maximum and minimum moduli for alpha uranium from single crystal measurements are also plotted [62, $63]$. 
values were obtained from specifically oriented uranium single crystals [63]. These results show that, whereas the modulus of non-textured polycrystalline uranium at $298 \mathrm{~K}$ is $29 \times 10^{6} \mathrm{psi}$, it can be as high as $41.5 \times 10^{6} \mathrm{psi}$ or as low as $21.4 \times 10^{6} \mathrm{psi}$ for a textured sample.

Finally, the authors were unable to obtain any reliable data on the influence of dilute alloy additions (e.g., 2 weight percent Mo) on the elastic properties of uranium.

$\underline{\text { Lead }}$

The influence of temperature on the Young's modulus of cast high purity lead is shown in Figure B-8. Again, increasing temperature results in a gradual decrease in modulus. Attempts to locate more complete information, including values of the shear modulus and Poisson's ratio, have been unsuccessful to date.

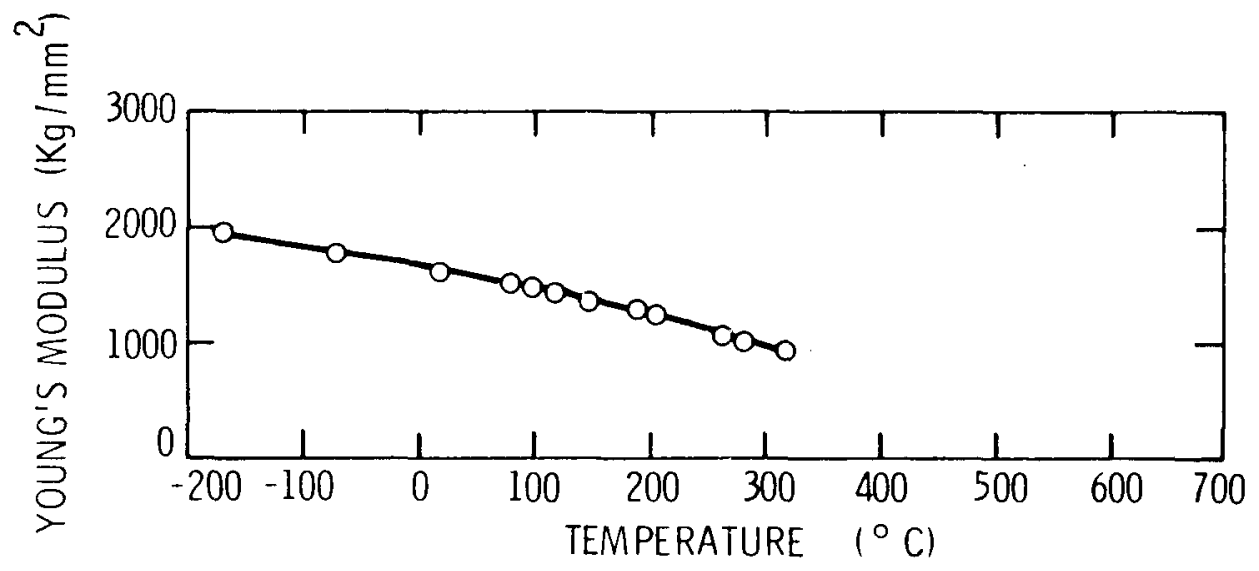

Figure B-8. Young's modulus of lead [65]. 


$$
\begin{aligned}
& \text { APPENDIX C } \\
& \text { List of symbols } \\
& \sigma \quad=\text { true stress } \\
& \sigma_{\mathrm{p}} \quad=\text { proportional limit } \\
& \epsilon=\text { true plastic strain }=\ln (1+e) \\
& \text { e } \quad=\text { engineering strain }=\Delta l / 1_{0} \\
& \epsilon_{\mathrm{L}} \quad=\text { total true strain } \\
& \mathrm{E} \quad=\text { Young's modulus } \\
& \Delta \mathrm{L} / \mathrm{L}_{\mathrm{O}}=\text { thermal linear expansion, } \\
& \mathrm{L}_{\mathbf{T}} \quad=\text { length at temperature } \mathrm{T} \\
& \text { Lo }=\text { length at } 293 \mathrm{~K} \\
& \Delta \mathrm{L}=\mathrm{L}_{\mathrm{T}}-\mathrm{L}_{\mathrm{O}}
\end{aligned}
$$


DISTRIBUTION :

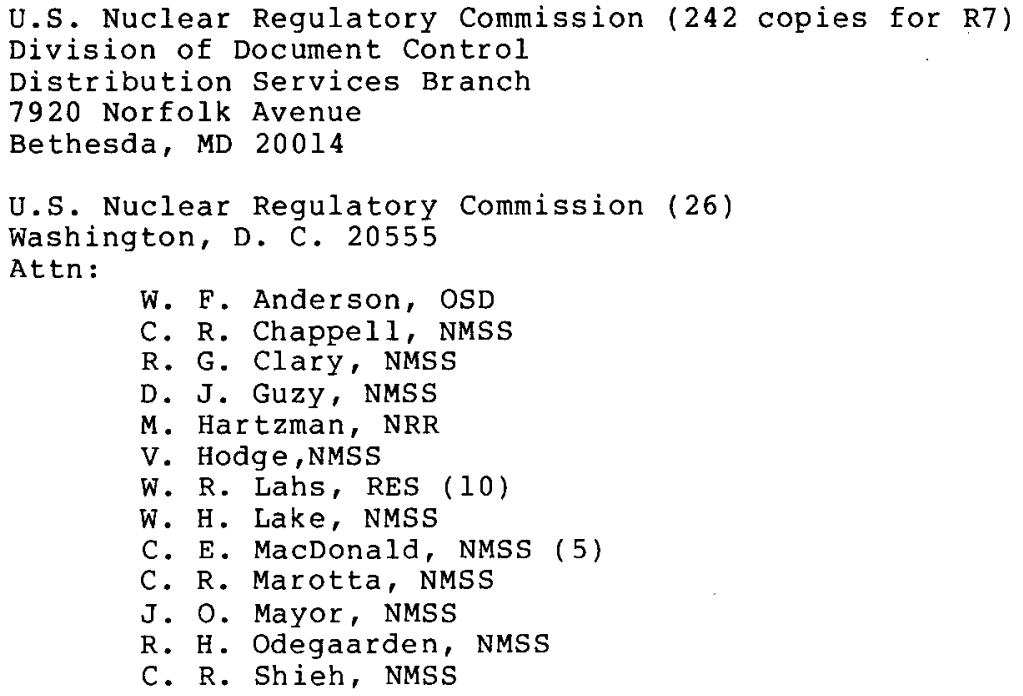

3141 T. L. Werner (5)

3151 W. L. Garner (3) For DOE/TIC (Unlimited Release)

3172-3 R. P. Campbel1 (25)

8266 E. A. Aas 